UNIVERSIDAD NACIONAL DE LA PLATA

FACULTAD DE HUMANIDADES Y CIENCIAS DE LA EDUCACIÓN

SECRETARÍA DE POSGRADO

PROGRAMA DE MAESTRÍA Y DOCTORADO EN CIENCIAS SOCIALES

\title{
Sellos emergentes en La Plata: \\ nuevas configuraciones de los mundos de la música
}

\section{Ornela Boix}

Tesis para optar por el grado de Magíster en Ciencias

Sociales

Director: Dr. Pablo Federico Semán,

IDAES-UNSAM.

Codirector: Mg. Rodolfo Martín Iuliano,

FaHCE-UNLP.

La Plata, 8 de julio de 2013 
Índice

Agradecimientos ...........................................................................................................................

Introducción ...............................................................................................................................................5

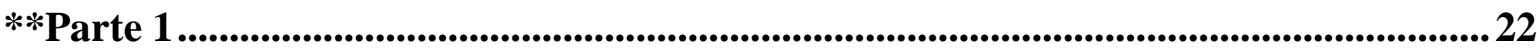

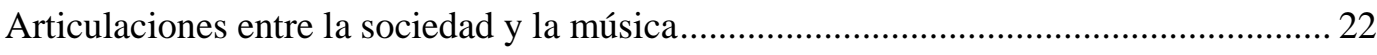

La música como una sociedad plena de mediaciones.....................................................2 24

La música como habilitación de una pluralidad de usos .............................................. 30

Una nueva música de uso ...................................................................................... 35

De la escena al sello: el proceso de construcción del objeto ……………………………..... 38

** Parte 2 ..................................................................................................................................................... 44

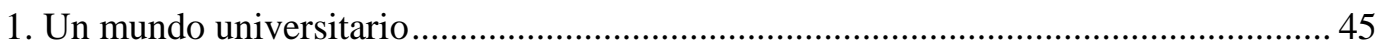

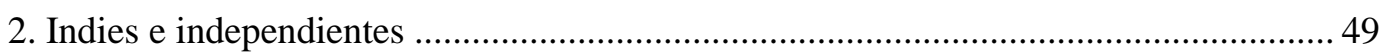

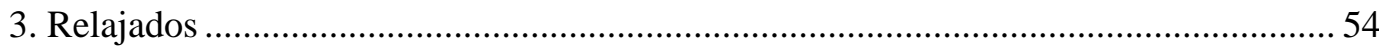

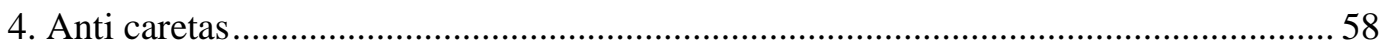

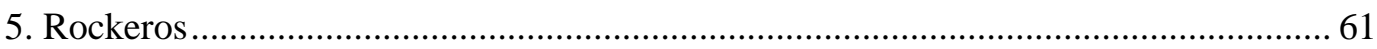

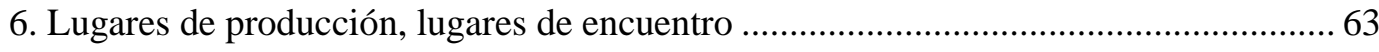

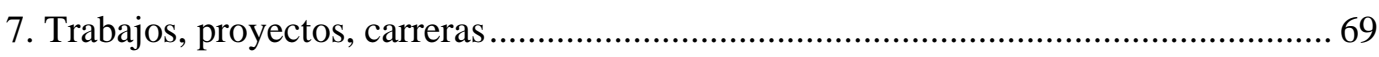

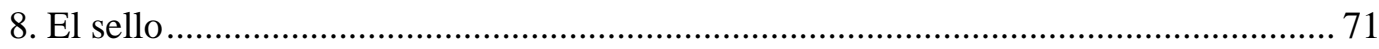

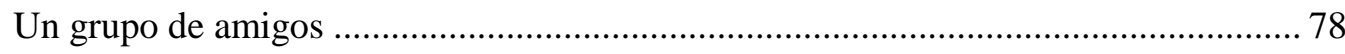

Formas y representaciones del trabajo artístico............................................................. 84

Los sellos en la producción musical emergente ............................................................ 86

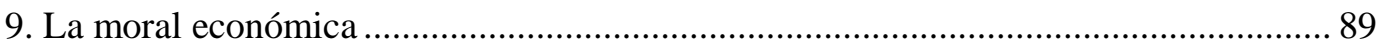

10. Los aliados: recursos estatales y gestión …………………………………………..... 93

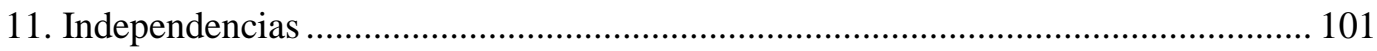

Conclusiones................................................................................................................................106

Bibliografía citada ......................................................................................................................... 115 


\section{Agradecimientos}

Primero, a quienes esta tesis compete de la forma más directa posible. A mi director Pablo Semán por su orientación y estímulo intelectual, su compromiso con mi trabajo, su complicidad y sentido del humor y su des-dramatización (manteniendo una obsesión productiva), de lo que una tesis ("la pinche tesis") significa.

A Rodolfo Iuliano, quien además de co-director operó en este proceso como segundo terapeuta. Gracias por escucharme y aconsejarme, ampliando siempre mi horizonte.

A ambos, gracias por la convicción de la relevancia de los objetos que para otros son "ilegítimos", "incómodos" o simplemente triviales.

A todas las personas que conocí haciendo esta investigación y que se prestaron (y se prestan) a pasar su tiempo conmigo, especialmente a toda la gente en Concepto Cero (en particular a Nicolás Madoery), TICA Red y sus alrededores, por admitirme en el tránsito de sus redes. Sin exagerar, cambiaron mi manera de pensar la música, manejaron la extrañeza de la práctica etnográfica mejor que yo y permitieron, en definitiva, la existencia misma de esta tesis.

A Juan Piovani, por haber abierto tempranamente para mí la posibilidad misma, pero también el espacio institucional, de una sociología empírica de la cultura. Refiero a mi adscripción al seminario/taller de Sociología y Literatura, al cual retrospectivamente veo como uno de los espacios más importantes de mi formación, haciendo extensivo este reconocimiento a los compañeros del espacio.

A las autoridades y al personal de la Maestría en Ciencias Sociales de la Universidad Nacional de La Plata por las gestiones y la dedicación.

A los docentes del seminario y taller de tesis de maestría, Mariana Busso, Sebastián Benítez Larghi, Leticia Muñiz Terra y Matías Iucci, quienes junto a los compañeros que comentaron mis avances, me orientaron en la formulación de un proyecto y me hicieron imaginar una tesis posible. En este punto, gracias también a Jerónimo Pinedo, quien luego de ser evaluador de mi tesina de licenciatura continuó su entusiasmo y generosidad con mi investigación. También a Guadalupe Gallo, José Garriga, José 
Buschini y Ramiro Segura, que de diferentes maneras me permitieron pensar mi tema y llegar a este resultado.

A las autoridades, compañeros y amigos del CIMeCS, lugar de radicación de mi beca CONICET, por el estupendo clima laboral, las conversaciones catárticas y los innumerables almuerzos, meriendas y cenas. Especialmente por su interés y consejos sobre mi trabajo a Lucas Alzugaray, Florencia Bravo Almonacid, Amalia Eguía, Nicolás Herrera, Laura Peiró, María Eugenia Rausky, Gustavo Robles y Luis Santarsiero.

A mis compañeros y amigos de la carrera de sociología, con quienes compartí y comparto mucho más que un camino formativo: Eray Arce, Mercedes Albo, Nicolás Welschinger, Andrés Stefoni, Josefina Lamenza, Marcos May, María Emilia Di Piero y Federico Naspleda. Agradezco especialmente a Martín Castilla, quien en su carácter de sociólogo, músico y amigo, leyó avances de esta tesis y charló conmigo cantidad de veces sobre el tema. También les doy las gracias a las compañeras de la carrera Julia Hang y Sofía Burry que leyeron partes de este trabajo y realizaron fructíferos comentarios.

Asimismo, muchas gracias a Celeste Sangiao, Libertad Jorquera, Nicolás Rinaldi, Estefanía Diana, Ailin Moreno, Bernarda Andornino, Walter Defrick, Camila Mayorga, Lina Jacovkis, Mariela Radicioni, Laura Pedro, Claudia Pantoja y Nicolás Carlino por acompañar desde distintos lugares y maneras este proceso.

Por último, quiero dedicar esta tesis a mis padres, Carlos Boix y Patricia Bermani, y a mi hermana Florencia Boix.

Ornela Boix Julio de 2013, La Plata. 


\section{Introducción}

A las doce del mediodía, el espacio cerrado del Parque Saavedra, ubicado entre las calles 12, 14, 64 y 68 en la zona sur del cuadrado de la ciudad de La Plata, comenzó a ser montado para el evento. Todavía en casa, yo veía por Facebook las fotos que Nicolás, músico y miembro fundador de Concepto Cero ${ }^{1}$, un sello musical con el que realizo mi trabajo de campo, subía a su Instagram: reconocí a Cristian y a Joaquín manipulando una media sombra donde podía leerse el nombre del festival de "sellos"2 musicales que estaba anunciado a las dos de la tarde: La Nueva Energía. Pero el festival, cuyo subtítulo aclaraba "Encuentro de sellos de música emergente", había empezado para un conjunto de músicos pertenecientes a una red de sellos de la provincia de Buenos Aires a fines de febrero: reuniones entre músicos, idas y vueltas con la Municipalidad y los encargados del Parque, controversias para definir la lista de artistas y el nombre del evento, gestiones con "amigos" del periodismo (incluyendo varias entrevistas radiales y en blogs especializados en música y arte), bocetos de los afiches y flyers $^{3}$, búsqueda de los equipos de sonido y otros recursos para materializar la música, obtención de la media sombra y de otros materiales para vestir el escenario, etc.

Finalmente ese día se armaron dos escenarios, uno de ellos acústico, ubicado en una glorieta del parque. De nueve sellos bonaerenses distintos, tocaron siete bandas y dos solistas, todos los cuales se habían anunciado días atrás por Facebook y otras redes sociales como Twitter ${ }^{4}$, incluso con la producción de un breve video. Si alguna persona ajena a este mundo hubiera revisado los perfiles en Internet de estos artistas para darse una idea de lo que se escucharía esa tarde, se hubiera encontrado en la perplejidad de leer definiciones tan aparentemente lejanas entre sí (y quizás desconocidas) como "rock stoner", "rock psicodélico" y "hard rock" junto a "dream pop", “indie pop”, “ambient

\footnotetext{
${ }^{1}$ Ver http://conceptocero.com/

${ }^{2}$ Con comillas marco nociones propias del grupo analizado, en casos de repetición señalo este carácter sólo en la primera aparición del término (siempre que no afecte la comprensión del texto). También se indican con comillas fragmentos de conversaciones.

${ }^{3}$ Se llama así a los volantes que publicitan los eventos.

${ }^{4}$ Facebook y Twitter son redes sociales de Internet donde pueden compartirse con "amigos" o "seguidores" distintos materiales textuales, fotográficos, audiovisuales, entre otros. Instagram es una aplicación gratuita para compartir fotografías con la que los usuarios pueden aplicar efectos fotográficos, generalmente de estilo "retro" o "vintage" y luego compartirlas en diferentes redes sociales virtuales como las mencionadas.
} 
rock", "shoegaze", "noise”, e incluso “canción popular melodramática”. También habría visto la adscripción de estas bandas y solistas a categorías como "indie" e "independiente".

En los caminos y límites alrededor de los escenarios se colocaron algunos puestos de indumentaria realizada de forma artesanal, incluido el de un colectivo dedicado a las artes visuales y el diseño que venía realizando fiestas con uno de los sellos participantes. También los organizadores habían armado una "feria de discos", donde se podían adquirir los materiales de las bandas que tocarían esa tarde noche y de los sellos en general. No sólo discos, también remeras, pins, dibujos y fanzines. Tras el escenario principal, entre el follaje, se veían una serie de autos de algunos músicos con los que habían llegado al lugar y transportado sus instrumentos junto a los equipos (de bajo, de guitarra, etc.) que, en algunos casos, les habían tocado aportar en la distribución que se había comenzado a hacer semanas atrás entre los artistas.

A las tres y cuarto empezó a tocar la primera banda, si bien todavía no había mucha gente: la mayoría de quienes observaban y escuchaban atentos eran los músicos de los sellos organizadores y de las otras bandas que se presentarían más tarde. También se encontraban varios fotógrafos: de Concepto Cero (uno de los sellos que impulsó el encuentro) y de las bandas, generalmente amigos de los músicos. Nos saludamos con varios de los músicos que había conocido el año anterior durante las capacitaciones de un programa estatal de "profesionalización" de la música emergente para colectivos musicales. Asimismo me encontré con novias, hermanos, amigos y amigas de los protagonistas. Poco a poco la gente, casi siempre en grupo, empezó a llegar. Entre estos grupos, reconocí a un número nada despreciable de estudiantes universitarios de la ciudad. Los conocía de verlos de todos estos años: en los recitales, en las fiestas, en los pasillos de la facultad de Humanidades, en el comedor universitario cercano a la Facultad de Bellas Artes, en las calles del cuadrado.

A lo largo de toda la tarde, chicos y chicas de no más de treinta años aprovechaban para ubicar panes rellenos, masitas y tortas caseras. Algunas personas tomaban mate junto a otras que fumaban marihuana. Mientras, quienes se estaban responsabilizando de la organización - un grupo de no más de diez músicos varones de menos de 30 años pertenecientes a los sellos-, iban del escenario principal al secundario, subían y controlaban los equipos, luego visitaban la feria de discos, daban indicaciones a los distintos sonidistas, hablaban con periodistas, con los fotógrafos, con los otros músicos, a veces riendo cómplices con ellos. En una continuidad prácticamente no 
interrumpida, los recitales se sucedieron hasta las 9 de la noche. Ya no reconocía a nadie: el espacio se había colmado. Estaban tocando las últimas bandas y se notaba que habían traído consigo seguidores que tarareaban sus temas y se contoneaban tímidamente.

Las repercusiones no se hicieron esperar: desde el día siguiente, y durante la semana que le sucedió, distintos materiales fueron producidos a partir del evento: en Facebook la red de sellos que lo había organizado publicó las fotos tomadas por sus fotógrafos oficiales, pero estas no fueron las únicas imágenes compartidas: los fotógrafos de las bandas y el público amigo también se abocaron a esa tarea. Varios periodistas y estudiantes de periodismo con cierta participación en este mundo musical sacaron sus notas: en blogs y algunas revistas dedicadas a la materia. Otros participantes subieron a YouTube o Vimeo capturas audiovisuales - a veces con un grado de edición considerable- de las presentaciones de algunas bandas. Varios músicos protagonistas del evento publicaron sendos estados en las redes sociales, narrando su experiencia y la satisfacción que les daba haber formado parte de ella.

¿Cómo llegaron estos músicos a producir un evento de esas características? ¿Bajo qué procesos se habían conocido y de qué formas trabajan juntos? ¿En qué condiciones habían entrado en relaciones con el Estado para conseguir un espacio correspondiente a su nivel municipal? ¿De qué manera habían convocado y formado a un "público" que se había vuelto productor del propio evento? Asimismo, ¿qué papel jugaban en todo esto los sellos? Más bien y en primer lugar, ¿qué es un sello exactamente?, ¿por quiénes está compuesto?, ¿cuál es su relación con los proyectos y las apuestas de estos actores en relación a la música?, ¿cuál es la gravitación de las nuevas tecnologías en esos usos y expectativas? ¿A qué refiere la idea de música emergente? ¿A qué, las distintas invocaciones a lo independiente y lo indie que esos artistas y sellos realizan en sus presentaciones públicas? ¿De dónde provenían estas palabras, qué tradiciones acarreaban para estos actores?

Desde fines del año 2009, cuando comencé mi trabajo de campo alrededor de la música, comparto con distintos músicos, la mayoría varones, que responden a alguna de esas categorías noches de recitales, reuniones diurnas para organizar festivales y tomar decisiones al respecto de la edición de discos, juntadas para charlar de nuevos proyectos, viajes a Capital Federal, conversaciones de chat, grupos privados de Facebook...Fui conociendo en profundidad un mundo del arte singular articulado en torno a la producción de música, plagado de jóvenes que se reconocen a sí mismos 
como parte de una generación ${ }^{5}$. Exhiben como importantes valores la gestión de la propia práctica musical (generalmente, pero no siempre, reivindicada bajo el término "autogestión"), la "independencia" y también formas de relacionarse entre ellos, más "solidarias" y "relajadas" que las de las generaciones anteriores. Plantean asimismo la necesidad de aprender y ejercer otros roles para llevar adelante sus proyectos. Así, haciendo trabajo de campo lo más común es que las actividades de quienes acompaño sean múltiples: cantar o tocar algún instrumento, sí, pero también probablemente haya que "hacer el sonido", “grabar”, "mezclar”, "masterizar”, “diseñar” el flyer, los banners, las tapas del álbum o bien la página web, "sacar fotos", "producir" (generalmente un evento: recital, festival, etc.), hacer de "manager" (aunque esta sea, como se verá, "una palabra horrible") como también reunirse con funcionarios estatales para conseguir "lugares" o subsidios. La fluidez en las posiciones y actividades me atravesaba al punto que, por ejemplo, pasaba de "investigadora" a "la chica de la feria de discos" o "la chica de la puerta". De esta forma, mi propio desenvolvimiento en el campo me empezó a mostrar, y finalmente me permitió entender, el modo de producción musical que describiré en estas páginas.

En particular, en La Plata, ciudad donde realicé mi investigación, denominaciones como indie, independiente y emergente obtienen una adhesión variable y discutida, como se verá en el apartado Indies e Independientes, a la vez que se han vuelto muy visibles para quienes circulamos en ambientes universitarios modulados por sensibilidades artísticas. ¿Cómo han llegado estas denominaciones a volverse comunes y relativamente centrales al interior de la música identificada no sin conflictos y al mismo tiempo con lo juvenil y las clases medias? Para aproximarse a una respuesta, hay que considerar un movimiento que se remonta al menos a la década del noventa. En aquellos años el rock nacional asumió, por un lado, un giro hacia el espectáculo con el respectivo ingreso al show business y al gran público (Alabarces et al 2008), por el otro, desarrolló una vertiente que hoy se podría denominar populista, tanto por su temática como por su estilo. La prensa especializada y el mundo del rock llamaron a este fenómeno de enraizamiento del rock en los sectores populares, que en ciertos casos también llegaba a llenar estadios, "rock chabón". Se trataba de un rock nacionalista, bailable (desligándose así de una pesada tradición intelectualista), democratizador en la

5 Siguiendo a Mannheim (1993) refiero a la situación de una generación que se descubre y llama a sí misma como tal. Este fenómeno, denominado por el autor conexión generacional, es distinto de la posición de generación, dada por el mero hecho del nacimiento en un período cronológico determinado. 
relación entre "productores" y "receptores". Esta sensibilidad, más que género musical, construía una epopeya con los marginales y contra la represión policial. Se "lamentaba el fin del mundo del trabajo y protestaba más que por el exceso de integración (que angustiaba a las primeras generaciones de rock nacional) (....) por su déficit” (Semán 2006: 206). Frente a ambos fenómenos, y radicalizando el histórico conflicto alternativo/comercial hacia el interior del mundo del rock, se desplegaba una modulación particular que aportaba más a los sentimientos y al glamour, privilegiando el intimismo por sobre lo social (Gallo y Semán 2009). Se trataba del llamado rock y pop "alternativo" e incluso indie. Luego de la tragedia de Cromañón ${ }^{6}$ y la descalificación del rock chabón (las críticas retrospectivas al género por una "pobreza" estética que lo hacía prácticamente culpable del incendio), estos modos alternativos adquirieron la posibilidad de hacer valer su propuesta, una propuesta que ya había conformado un radio de acción y una legitimidad propia. De esta forma, en un proceso que no puede ser fechado con exactitud y que prácticamente no ha sido estudiado, el espacio de la música considerada juvenil en la Argentina se abrió a una renovación temática y estilística, delineándose un fin de ciclo que ya mostraba signos de agotamiento.

Se trata de un universo de producción estética donde los músicos han incorporado la gestión de sus proyectos musicales - una manera activa de relacionarse con distintos actores e instancias que median y articulan la música, no sólo con dinero-, a la vez que tocan, y lo hacen muchas veces en varios proyectos a la vez, produciendo una agitación cultural muy rica y heterogénea. El contraste con otros períodos puede ayudar a restituir esta efervescencia, en relación a la relativa facilidad con la que cuentan hoy los músicos para grabar y difundir sus materiales. Para esta comparación, no es necesario remontarse a la época del vinilo. Basta recordar que en Argentina el formato casete siguió siendo predominante hasta mitad de la década del noventa dentro de la música "alternativa": muchas bandas independientes de entonces editaban sólo en dicho soporte, dado que los costos para acceder a una grabación en CD eran muy altos. Con el abaratamiento y difusión de las computadoras hogareñas se abrió para los usuarios la posibilidad de grabar por sí mismos y no depender para ello de la inversión

\footnotetext{
${ }^{6}$ Con la tragedia de Cromañón se refiere el incendio de la noche del 30/10/04 durante un recital de la banda de rock Callejeros que causó la muerte de 193 personas La bibliografía suele marcar cómo esta tragedia trajo cambios para la ejecución de la música en vivo (ver, por ejemplo, Corti 2009 para la ciudad de Buenos Aires; Cingolani 2013 para La Plata).En el campo que aquí se presenta, Cromañón significa un cambio claro con respecto a la responsabilidad del músico con respecto a sus condiciones de ejecución en la música en vivo, por lo que los saberes de gestión se valorizan también recurriendo a ese episodio.
} 
de las compañías discográficas, lo que ha reconfigurado sensiblemente el mercado de la música (Ochoa 2003; Yúdice 2008; Fouce 2010) ${ }^{7}$.Actualmente, los relativos bajos costos de los equipos y la disponibilidad de softwares de edición musical permiten para los trabajos terminados una calidad cercana a un sonido "profesional", preocupación, no obstante, que no siempre aparece en los músicos emergentes. En este panorama, donde es posible componer, grabar, difundir y consumir los productos musicales sin salir de casa, comenzaron a surgir distintos tipos de emprendimientos de músicos que intentan posicionarse en la nueva situación. Los sellos online (a veces llamados netlabels) y los sellos del tipo que será objeto de esta tesis intentan imprimir en un contexto de sobreoferta musical cierta identidad, cierto estilo, cierta diferencia.

Uf Caruf, Dice Discos, Concepto Cero, Mandarinas Records, Cala, Tomas del Mar Muerto, Tsunami Records, Laptra, Choco Discos, Tigra, Tupé Records, entre otros, pueden contarse entre los sellos activos en la ciudad hacia el momento que escribo esta tesis. Sin embargo, la expansión del fenómeno excede con mucho esta geografía urbana alguna vez planificada, articulada por diagonales y marcada por la presencia protagónica de los estudiantes universitarios. Durante el año 2010 trabajando cerca del sello Tigra, y a partir del año 2011, de la mano del equipo de Concepto Cero, pude conocer directamente a muchos de los protagonistas de otros sellos y colectivos de la zona metropolitana de Buenos Aires, señalada generalmente en la bibliografía académica y en el sentido común social como epicentro de este tipo de actividades culturales. Pero también, siguiendo la conformación de una red de sellos bonaerense conformada en el año 2012 y su participación en un programa estatal de "profesionalización" de la música "emergente" con perspectiva federal, me encontré con quienes llevaban adelante sellos de similares características en otros centros urbanos, tales como Córdoba, Mar del Plata, Rosario, Bariloche, Tucumán y Formosa ${ }^{8}$.

En todos estos casos, se trata generalmente de varones "jóvenes" en un sentido etario pero también, como dije, en su reivindicación generacional, vinculados a la

\footnotetext{
${ }^{7}$ Como lo sintetiza Fouce (2012) el viejo modelo de la industria de la música que hoy se encuentra en una crisis manifiesta estaba fundado en tres pilares: 1) la venta de discos (gestionado por las discográficas), 2) los derechos de propiedad intelectual (gestionados por las editoriales, habitualmente ligados a las casas de discos), 3) el directo (gestionado por los músicos a través de un mánager). En este modelo, basado en la cultura del fracaso (era preciso un número ingente de fracasos comerciales para lograr un éxito capaz de salvar esas pérdidas), era el disco el que iniciaba el ciclo de la música, de allí la preponderancia de las grandes discográficas.

${ }^{8}$ De acuerdo a la procedencia de los sellos con los que he tenido contacto a lo largo del trabajo de campo: Ringo Discos (Córdoba), Desde el Mar y Pistilo Records (Mar del Plata), Polvo Bureau (Rosario), Safari Colectivo Patagónico (Bariloche), Yo con Voz (Tucumán), Mamboretá Records (Formosa), entre otros.
} 
música de maneras que exceden el manejo de un instrumento y agrupados con el objetivo de empezar a tener cierta presencia en "la escena" o "el mercado", espacios cuyo sentido en este mundo musical ya se desarrollará. Cuando se habla de sello, se habla por lo general de un colectivo de personas que suelen referirse mutuamente como amigos y que se define en primer lugar en cuanto a la producción de música, ya sea su edición en discos -físicos y/o virtuales- y/o su presentación en eventos de variado tipo, no produciéndose la identificación primaria a partir de un género musical, cuya erosión ya ha sido planteada para otros contextos en el marco de la pluralización de la producción y las escuchas (Ochoa 2003, Semán y Vila 2008). A los fines de la producción de discos, estos proyectos asumen para sí las consecuencias del establecimiento de novedosos modus operandi de grabación y de difusión, especialmente Internet: graban en estudios hogareños o montados por amigos y se difunden principalmente a través de las redes sociales virtuales.

Por otra parte, por más que centralmente hagan música, la mayoría de estos colectivos se dedica a otras producciones estéticas que presentan a su par, dándoles una importancia que no puede ser ignorada. La música siempre es presentada en un cruce de manifestaciones estéticas: recitales que son también muestras de plástica, sellos que editan fanzines ${ }^{9}$ además de discos, bandas que hacen sus propias películas, recitales donde se declama poesía, ferias de objetos y prendas de diseño musicalizadas por cantautores. Si bien en algunos casos estos agrupamientos pueden definirse a partir de expresiones como "productora de contenidos", "plataforma de artistas" o "colectivo multidisciplinario", el sello se constituye para los distintos participantes de la escena en la manera hegemónica de otorgar inteligibilidad a las interacciones a su interior. Pero además, para los músicos de los sellos y sus amigos, es una forma de producir sentidos de pertenencia, como se desarrollará más adelante. ¿Por qué simplemente sello y no sello discográfico? ¿Qué otras producciones centraliza el sello y cómo las articula con la música? ¿Cuál es la relación de los artistas con el sello? ¿Cuál, con las actividades y productos realizados (ediciones físicas y virtuales de discos, recitales, festivales...)? ¿Cómo funciona un sello de estas características? ¿Cómo se producen identificaciones alrededor de él? ¿Es meramente un "paraguas" o un "sellito" para agrupar proyectos

\footnotetext{
${ }^{9}$ Se llama así a una publicación generalmente artesanal y de carácter aficionado, donde se compilan diversos tipos de escritos y/o imágenes. Es regla su distribución gratuita, por lo que no suelen implicar remuneraciones económicas para sus productores. En mi campo se sostenían con inversiones propias y/o con publicidades.
} 
afines como me dijo alguna vez un músico de Tigra? ¿Entonces resultaría constituirse en, como traducen algunos trabajos, un operador simbólico? ¿Es acaso una especie de pequeña empresa, como plantean algunos autores que han abordado este fenómeno?

Estos sellos suelen ser identificados en La Plata con la "escena independiente", un conglomerado de "redes" de trabajo colaborativo, que cuenta con escasos lugares físicos propios y exclusivos de la escena y que se despliega especialmente durante el período escolar, es decir de marzo a diciembre. Esta escena tiene a los estudiantes universitarios como sus protagonistas: todos ellos, aunque no sean músicos, se hayan implicados de alguna manera en la producción estética en su más amplio sentido, su comunicación a través de distintos medios (redes sociales, radios comunitarias y universitarias, revistas, fanzines, blogs, secciones especializadas en los periódicos locales, etc.) y su consumo. En realidad, a través de sus prácticas al interior de la escena musical,estos actores redefinen las formas en que se produce y se consume lo que ya ha sido señalado para otros contextos, especialmente en el cruce de la juventud y los usos de las nuevas tecnologías (Martín Barbero 2009, García Canclini 2004, Vila 2010). En este sentido, retomo de Weber y Mitchell (2008: 27), la actualización del uso del término prosumidores (del inglés "prosumers", acrónimo formado por la fusión de las palabras producer - productor- y consumer-consumidor-) para referir a este proceso de transformación de dos categorías habituales para pensar las prácticas culturales ${ }^{10}$.

Dentro de esta escena circulan otras categorías relevantes al análisis, como la de indie, la cual intenta marcar cierta novedad dentro de la música juvenil. En su sentido fuerte, la categoría indie refiere a una modulación particular de la llamada "música independiente" identificable en ciertos grupos y solistas, mientras que en un sentido más laxo es utilizada para referir a una sensibilidad y/o un estilo, que los primeros portarían con ejemplaridad. Justamente, del indie no muchos pueden asegurar si se trata de un género musical, una estética, una forma de vestirse o un insulto, pero sí que se ha convertido en un significante relativamente central enlas revistas de "cultura rock" y en los suplementos culturales de producción y circulación nacional, los blogs, las redes sociales y las conversaciones en ciertos círculos universitarios donde se produce una disputa estética e intelectual. Por ello un primer interés de esta tesis es problematizar la noción de indie, cuya generalización amenaza dejarla sin sentido, en el marco de una pregunta por la particularidad de las prácticas musicales descriptas.

\footnotetext{
${ }^{10}$ Weber y Mitchell (2008:27), a partir del análisis de las nuevas tecnologías, quieren dar cuenta de cómo actualmente los procesos de producir y consumir están interrelacionados y a menudo son simultáneos.
} 
Se trate de indies, independientes o emergentes hablo de jóvenes que descreen de las grandes historias del rock nacional, que se alejan con desconfianza y también con ironía de las "estrellas de rock", y que aún así, o quizás por eso mismo, han llegado en ciertos casos a protagonizar tapas de suplementos y revistas de tirada nacional orientadas al público "joven”, como también han logrado la atención de grandes cadenas televisivas de música como MTV. Estas características los emparentan con las distintas nuevas generaciones de músicos que, bajo un típico modelo de la fracción heterodoxa que disputa la ortodoxia establecida en un campo (Bourdieu 1983) intentan entrar al mercado retando lo instituido, desafiando a las generaciones anteriores, disputándoles el espacio y las posiciones que en él han alcanzado. Sin embargo, los actores que analizo llevan incorporadas perspectivas de trayectoria y de éxito diferentes, que los oponen a las instituciones tradicionales del rock, produciendo una disputa moral con los establecidos, alterizando a nivel moral. Si bien este modelo de consagración y de profesionalización todavía está por construirse, y no pueden conocerse hoy sus posibles derivaciones, la investigación realizada devuelve la imagen de músicos cuyos caminos no parten del deseo de formar parte de las grandes ligas (o al menos ese no es su más fuerte deseo) ni tampoco de proyecciones acerca de su "descubrimiento" por intermediarios que los lleven a estrepitosos triunfos entre el gran público y el mercado.

Esto no significa que no les interese "vivir de la música", una preocupación permanente para ellos y, en algunos casos, vital ${ }^{11}$. El deseo de vivir de la música en el sentido de la obtención de ingresos funciona, por un lado, como una especie de fantasía de muy difícil concreción cuando parte de compararse con las grandes estrellas. Pero, por el otro lado, efectivamente ellos buscan formas de "vivir de la música": miden alternativas dentro de un mundo que no asegura entradas regulares pero que igualmente deja ingresos. Como se desarrollará en distintos puntos de esta tesis, se preocupan por no pagar para tocar, regulan la manera y el monto en el cobro de las presentaciones como en el regalo y trueque de discos, están atentos a los arreglos monetarios con las bandas con las que comparten la "fecha" y también, entre otras prácticas, analizan la posibilidad de monetizar otras producciones a partir de la música (muchas bandas venden sus propias remeras, pins, dibujos y otros objetos). Pero también se vive de la música de otra manera: como decía el cantante de unas de las bandas emergentes de la

${ }^{11}$ Como se verá en el apartado "Trabajos, proyectos, carreras" de la Parte 2, estos músicos se encuentran en distintas relaciones con la música a nivel de la búsqueda de ganancia, entre, por ejemplo, quienes lo consideran un ingreso suplementario o quienes deben contar con los ingresos en la música para complementar los de otras actividades rentadas. 
ciudad con la que realicé trabajo de campo: "todos hacemos otras cosas pero está esa sensación que uno lo hace para llegar a lo principal que es tocar. Estamos todo el día pensando en eso, hablamos entre nosotros todo el tiempo de eso". Podría hacer coincidir en esto al cantante de otra banda con la que trabajé cuando decía que desde este punto de vista "espiritual" también se vive de la música. Como se verá más adelante, la posibilidad de complementación entre carreras en la música y otras actividades es una posibilidad relativamente novedosa que estos músicos explotan de manera ejemplar.

En este contexto, en estos mundos se encuentran artistas que ya "consagrados" en los términos de la crítica especializada y los públicos trabajan en otras áreas para poder solventar presentaciones en el exterior o la producción de un videoclip, ya que no tienen los recursos de una compañía discográfica. Es así que el problema acerca de la forma y el sentido de la consagración plantea para ellos preguntas como: ¿qué significa hoy en día que una banda la "pegue", ¿quiénes van a ser las nuevas grandes bandas?, ¿así lo queremos?, ¿es eso acaso posible? Justamente la pregunta "nativa" por la consagración puede servir de puerta de entrada al problema de la particularidad de estos mundos del arte y su diferencia con otras músicas que hegemonizaron lo "juvenil" en épocas pasadas.

Alabarces et al (2008) afirmaban hace unos años que en materia de rock argentino últimamente "nadie inventa nada nuevo", refiriendo a un "desierto estético" que atravesaba las clases sociales y los géneros musicales. Estos analistas esperaban que la innovación fuera estética y se produjera bajo el formato de las bandas que parten de "los garages y las salas de todas las ciudades argentinas de mediano y gran porte" (Alabarces et al 2008: 42) y que luego, presumiblemente, llegarían a cruzarse con ellos en las tiendas de discos, a juzgar por el resto de los reconocidos artistas que nombran en su artículo. Si bien plantean que su afirmación no es legitimista, ya que el desierto es transclasista, cabe preguntarse: ¿desde qué lugar, desde que supuestos socialmente construidos sobre la innovación, se proclama un conservadurismo estético? Construyendo una imagen de un relativismo ingenuo, estos autores sostienen que la "renuncia al juicio y la evaluación" estéticas por parte del investigador se identifica con un "relativismo falaz, y como tal puro populismo, estético pero a la vez político" (Alabarces et al 2008: 58). Sin embargo, debe discutirse la asimilación que este trabajo realiza entre el juicio de valor aplicado a la música y un juicio que puede producir conocimiento específicamente en el plano de lo social, es decir, un juicio sociológico. Como plantea López Cano (2011), en una intervención al respecto de la necesidad de 
desnaturalizar la supuesta inevitabilidad de los juicios de valor sobre la música,el juicio musical es siempre un proceso social y sus términos no derivan de "la música en sí misma", sino de las instituciones y discursos específicos que en ese acto también la producen. Esto debería alertar acerca de que juicios al respecto de la calidad estética de la música colaboran a la construcción y perpetuación de un canon legítimo (el que sanciona sobre la verdadera estética) que regula la valoración de los productos y prácticas musicales de una comunidad. Por lo tanto, los juicios de valor deben ser concienciados en el discurso académico, deben ser tomados como objeto de investigación, una de las maneras en que los juicios de valor pueden producir conocimiento. La posición de López Cano no representa un relativismo ramplón, sino una postura reflexionada que descentra y desnaturaliza el gusto estético del investigador, logrando una implantación y una legitimidad en los estudios sociales de la música.

En el año 2009 comenzaba mi trabajo de campo con Tigra, un sello platense vinculado al indie para ver bandas que desde el garage terminaban tocando en el Personal Fest sin que la mayoría de la población de la ciudad de La Plata se enterara. Frente a ellos, se abría la sospecha de que producían música, trazaban sus trayectorias y obtenían éxitos de un modo muy diferente al de las bandas de décadas anteriores. En el campo se decía que innovaban en sus concepciones estéticas como también en su manera de pensarse como músicos. En este contexto, una pregunta sociológica por lo nuevo no puede partir del supuesto no analizado de que el criterio estético es también sociológico. Una pregunta por la innovación en esos términos pierde de vista el dato fundamental de la escala de estos mundos musicales y la relación de estos jóvenes con los medios de producción de música y con la música misma. En otras palabras, un interrogante así presupone un paradigma de relaciones con la música que ha comenzado a declinar mientras emerge una configuración alternativa (Gallo y Semán 2013). Y lo que se pierde de captar es esa misma emergencia de una configuración alternativa en la vinculación de los jóvenes con la producción de música.

Apelaciones a la música independiente, el indie, lo emergente-palabras con las que se habla generalmente de cosas distintas aunque muchos piensen que se habla de lo mismo- se han multiplicado en los últimos años como posibles respuestas a la pregunta por la novedad en lo musical. Primero en la prensa especializada de circulación nacional (revistas como Los Inrockuptibles o Rolling Stone, suplementos “jóvenes” como Sí de Clarín y No de Página/12) y en la de publicación virtual (cantidad de blogs, sites y 
revistas digitales), así como en ciertos libros dedicados al tema, antes que en las ciencias sociales, se han comenzado a presentar ciertas dimensiones de la práctica musical como "novedosas": las sensibilidades estéticas, los "sellos independientes", los roles que debe asumir el músico para no perecer en la industria, las prerrogativas de la propia gestión de la actividad musical, los "modelos de negocio" y los criterios de consagración posibles frente a la reconfiguración del mercado de la música, las bondades del trabajo colaborativo y de las redes, entre otras. Cuando realizaba trabajo de campo con Tigra se discutía mucho al respecto del "indie cabeza" y el "indie pulenta" como novedades en el plano de las sensibilidades. Como se verá la Parte 2, se trata de expresiones elaboradas por periodistas y organizadores de eventos para plantear una novedad radical con respecto a la música "alternativa" de los noventa. Luego, entre mis informantes de Concepto Cero y de la red TICA se discutía más que nada de las "nuevas formas de gestión". Circulaba en particular un libro llamado "Música para Camaleones". Producido de forma colectiva por Trànsit Projectes (2012) en el marco de la crisis española, se propone como un muestrario de referencias en "buenas prácticas" de trabajo en producción cultural y, específicamente, en la música. A partir de la presentación de 29 proyectos que se proyecta que marquen pautas y formas de trabajo para los lectores “emprendedores" en cultura, "Música para Camaleones" quiere demostrar que la novedad radica en el "cómo", es decir, en la metodología de trabajo. Es esta forma la que hace "destacar la belleza de una piel en apariencia tan poco singular que se parece a todas las otras pieles" (Trànsit Projectes 2012: 18). En otras palabras, la singularidad no está desde esta perspectiva en la obra por sí misma sino en la forma de producirla.

Al interior de la academia local, a partir de preocupaciones analíticas alrededor de estos temas, algunos trabajos recientes han indagado sobre la dimensión novedosa en la producción y consumo (ya se problematizarán estos términos) en la música emergente, pensándola a partir del prisma de las identidades que, como se desarrolla en la Parte 1, resulta el tipo de aproximación más común de la relación música/sociedad en el contexto nacional. Construyendo un campo cercano al que aquí se presenta, Peña Boerio (2011) describe el circuito indie del área metropolitana de Buenos Aires para encontrar en él un criterio de clasificación en la música juvenil urbana que combina nuevos modos de consumo y producción, ligados a las nuevas tecnologías, con valoraciones que tienen una larga tradición como lo es la libertad de creación artística. De esta manea, considera al indie como una identidad socio estética generacional de 
clase media posterior a Cromañón. Analizando tanto a los músicos como a los públicos, a los que encuentra en relaciones de cercanía y relativa horizontalidad, encuentra que forman una comunidad expresiva que plantea, con respecto a otras músicas que disputan lo "juvenil", una ruptura estética, política y etaria. Su trabajo, entonces, pone el eje en los atributos identitarios, presentes tanto en los músicos como en el público, que el indie como categoría permite conglomerar.

En este mismo campo problemático, pero desde un enfoque que resalta la dimensión económica y mercantil de la música, Quiña analiza en distintas publicaciones el nacimiento y la consolidación de un espacio musical independiente, que, según su interpretación, se halla solapado, en cuanto al estilo musical, con el indie (Quiña 2009a). Presenta la música independiente a partir del concepto de formación social (en el sentido de Williams 2000), entendiéndola como una respuesta que músicos, intermediarios y otros actores dan a la crisis del mercado discográfico que comienza en nuestro país en 1999. En este análisis, lo nuevo resulta una forma de producción musical que se habilita a partir de un contexto crítico, aprovechando la vacancia que habría dejado la caída de la industria discográfica, y que se alimenta de un nuevo impulso autogestivo en la cultura que tomó forma a partir del estallido social de 2001. Esta música se distingue por una lógica de lo inclasificable en relación al género musical, la pequeña escala de producción a nivel del tamaño, la importancia de las relaciones cara a cara y los afectos para su realización en cuanto a la dimensión vincular, la gestión del músico de su propio hacer musical con respecto al tipo de gestión. Sin embargo, a los fines de recuperar una mirada totalizadora, el autor plantea que en relación al mercado de la música en su conjunto, este espacio, sus sellos y sus músicos resultan una especie de semillero para el ámbito mainstream, es decir para las “majors” (Quiña 2009a, 2012). En otras palabras, es de allí de dónde surgirán las nuevas grandes bandas, alimentando los circuitos tradicionales de unas pocas y gigantescas compañías discográficas.

Quiña (2012) convierte a los músicos individuales en los sujetos claves de la investigación. Ellos están acompañados por otros, entre los que incluye a los sellos discográficos "independientes", los propietarios y gestores de espacios de música en vivo, las agencias de gobierno vinculadas a las políticas públicas hacia esta música, los intermediarios culturales, las organizaciones patronales y gremiales del sector y, finalmente, el público. En este marco, el énfasis de su análisis está puesto en las condiciones de producción esta música considerada como trabajo. Encuentra un gran porcentaje de empleo no registrado, una muy escasa contratación de trabajadores 
asalariados, una apelación laboral a los vínculos personales directos y altos niveles de riesgo. Las tareas que los músicos deben desarrollar son polivalentes, se realizan en condiciones insuficientes en materia de seguridad y con estándares de calidad musicales lejanos a los grandes emprendimientos editoriales o en vivo. En síntesis, Quiña presenta este mundo como signado por prácticas laborales informales, precarias y muchas veces impagas, sin embargo representadas por sus agentes como autónomas, auténticas y libres, valores asimismo vueltos hegemónicos por un nuevo capitalismo ya que sirven a la reproducción ampliada del capital. Más allá del tratamiento de las representaciones sociales como meros velos de una situación de precarización, la pregunta por la calidad de prácticas musicales que se significan como trabajo es sociológicamente relevante. Su énfasis en la informalidad y precariedad del sector se contextualiza en un mundo caracterizado por vínculos lábiles y trabajos precarios o transitorios. Para Quiña la condición precaria resulta la forma hegemónica de contratación de la fuerza de trabajo, no meramente privativa del trabajo musical y "creativo", sino característica del patrón de acumulación posfordista. Este énfasis en la formación subalterna de los músicos independientes, sin embargo, no se corresponde con su descripción de las condiciones de producción musical en este ámbito, cuya configuración es para esta tesis un cambio de escenario desde el cual hay que comprender la posición y el trabajo de los músicos. Es decir: este específico modo de producción (y por lo tanto de usos de la música) tiene consecuencias igualmente específicas a nivel de las carreras y de la representación del trabajo en la música. Esta especificidad no se reduce a la precariedad, característica que, por otro lado y según el autor, define al resto de posibilidades laborales en el mundo capitalista contemporáneo. Al otorgar primacía analítica a la dimensión de unas relaciones laborales que niegan la desigualdad y la explotación, es decir el conflicto capital-trabajo, Quiña se priva de apreciar la novedad que la configuración musical independiente puede significar.

Por su parte, en un planteo en buena medida contemporáneo al anterior y a esta investigación, Vecino (2011) ha interpretado la consolidación y expansión exitosa de la música independiente como la de un subcampo de producción restringida (Bourdieu 2010: 90) al interior de la producción musical a partir de la conformación de una cultura de producción (Negus 2005) específica sobre la base de trayectorias individuales articuladas por sellos discográficos pequeños y medianos. El contexto económico desfavorable también resulta un elemento explicativo relevante en su análisis, donde asume una periodización del fenómeno que se superpone a la de Quiña. No obstante, a 
diferencia de este, su trabajo da valor operativo a la "ideología de la independencia" típica de estos sellos discográficos, basada en valores que indican lo novedoso (lo "nuevo", lo emergente, lo "distinto") acompañados de una vinculación que recupera el amor por la música. En este sentido en un trabajo anterior, el mismo autor refiere en estos sellos la irrupción de nuevas sensibilidades que se pretenden modernizadoras de los mecanismos "tradicionales" de producción y consumo de música (Vecino 2010: 2). Considera que la ideología de la independencia, lejos de ocluir la dinámica mercantil y capitalista de la producción musical, funciona como una reivindicación tanto moral como estética y como una cultura de producción. Para Vecino, esta ideología, por un lado, favorece el surgimiento de sociabilidades musicales definidas por las distintas comunidades de género; a la vez, sienta las condiciones de la autonomización del subcampo de producción. Este proceso se realiza a partir de un repertorio de decisiones que sustrae a estos nuevos sellos de las estrategias tradicionales de producción de los grandes sellos discográficos, asegurando de esta manera su supervivencia y, eventualmente, su éxito comercial (Vecino 2011). Dado que su análisis se centra en el sello como un emprendimiento clave en el subcampo de la música independiente, resultando un acierto la centralidad que da a las prácticas de producción, se volverá sobre él en la Parte 2 a la luz de los hallazgos empíricos construidos sobre sellos.

En México, Woodside Woods, Jiménez López y Urteaga Castro Pozo (2011), bajo la orientación de Néstor García Canclini, estudian la escena de la música popular alternativa, a la cual consideran emergente. Si bien no definen ni teorizan esta categoría, de la lectura pueden derivarse algunos sentidos: se es emergente en términos generacionales, en relación con lo establecido o lo dominante, en cuanto a las estrategias y dinámicas de posicionamiento en el campo del arte y en el mercado, en vinculación con el espacio social (se trata de configuraciones que desde la periferia van adquiriendo centralidad) y con respecto al contenido estético de innovación. Dando por descontada la crisis de un paradigma en la industria de la música, encuentran dinámicas novedosas de producción musical y de socialización alrededor de la música, habilitadas en gran parte por las nuevas tecnologías. Los autores piensan esta escena a partir de la idea de una red abierta y muy fluida de colaboración, compuesta por personalidades creativas que se encuentran en una permanente búsqueda de empleo. Describen una situación laboral autogestiva, creativa y multidisciplinaria tanto como flexible e informal, donde la obtención de dinero importa pero no asume centralidad para la continuidad de la actividad, dada la fuerte capitalización por vía familiar de estos 
jóvenes. Puede leerse en esta investigación, como en su continuación en García Canclini (2012), cómo el proyecto, entendido como el trabajo musical o estético en emprendimientos puntuales, es decir una especie de trabajo a destajo, se vuelve una noción clave, para analizar las prácticas musicales de la última década, una vez que se ha dado el tránsito de una sociedad en la que se podía "hacer carrera" a otra en la que el trabajo asume un carácter más inseguro. Para este autor, la periodización frágil de las actividades musicales entre los que llama jóvenes es una de sus características más acusadas, lo que le permite afirmar que hemos arribado a un momento donde los proyectos prevalecen sobre la carrera. Su análisis incorpora el dato de la informalidad y precarización laboral entre los jóvenes en distintos mundos de la práctica, es decir, el de una configuración social que ya no puede asegurar la estabilidad en líneas generales y no sólo en relación a la música.

¿Qué es, entonces, lo nuevo en la producción de música de los últimos años? Esta es una pregunta que se hacen los músicos y los artistas tanto como los periodistas y los críticos para finalmente encontrar interés también en los ámbitos académicos. ¿Se trata acaso de una nueva sensibilidad? ¿Se constituye esta música emergente como una nueva manera de producir identidades a partir de la música? ¿Es, más que nada, una forma novedosa de producir que encontró su lugar en los espacios que dejó la gran industria y, por lo tanto, está destinado a complementarla? ¿Se asiste, más bien, a la conformación de una cultura de producción específica? ¿Debe entenderse un cambio paradigmático donde los roles son móviles y es imposible pensar en carreras en la música? En otras palabras, las preguntas apuntan a interpretar la actividad efervescente en la música que ha proliferado en los últimos años. ¿Es, más que nada, subsidiaria de un cambio en el dispositivo económico de la industria discográfica? ¿Es el carácter mercantil lo que la define, en su camino (o no) hacia la gran industria? ¿Se trata, por el contrario, de actividades donde priman el ocio y el placer, alejadas de un interés económico? Entonces, ¿es solamente una práctica de ocio y de cultivo de una sensibilidad no vinculada con el trabajo?

De forma contemporánea a los fenómenos musicales y estéticos investigados, se ha desarrollado en el plano de los estudios sociales de la música una renovación teórica, crítica de una concepción mecánica de la relación entre música y sociedad, donde la primera sería determinada por la segunda. Este proceso teórico habilita una mirada donde la música es una relación al mismo tiempo que alerta sobre la pluralidad que pueden asumir sus usos. La música emergente que acá estudio, tanto por su 
especificidad como fenómeno social como por las nuevas concepciones al respecto de la relación entre la música y la sociedad, requiere tomar como nivel privilegiado del análisis el régimen de producción específico que la hace, justamente, emerger. Este nivel no ha sido generalmente apreciado en los estudios sociológicos sobre música, lo cual resulta problemático para un abordaje en la que la música y la sociedad no se hallan en exterioridad la una a la otra, sino en mutua imbricación.

Es en la especificidad de este cambio en el régimen de producción musical donde se encuentra la respuesta a la pregunta por lo nuevo. Es en prácticas que no pueden ser explicadas desde el punto de vista de la industria musical tradicional (la idea de un "semillero" o de una "complementación" al "mainstream", por ejemplo, dentro de un campo de la música estructurado verticalmente) ni tampoco solamente a partir de las nociones trabajadas de manera amplia y sostenida sobre la identidad y la identificación en la música. Con el objetivo de indicar este cambio en el régimen de producción, en esta tesis conceptualizaré a los fenómenos musicales en estudio como emergentes, para dar cuenta de los sentidos de novedad que inscriben en el campo de la música, a la vez que respetando la convención nativa que usa lo emergente a la manera de un adjetivo más global (y menos cargado en un sentido ideológico y estilístico) que indie o independiente, los cuales guardan diferencias que serán abordadas en el apartado "Indies e Independientes". Este proceso emergente no puede definirse en relación con lo dominante (en el sentido de Williams 2000), dado que se halla en plena conformación, mientras lo que ha sido hasta ahora dominante en la música se encuentra en crisis ${ }^{12}$, cuestión a la que se volverá a lo largo de la tesis y que se recuperará en las conclusiones. A fin de avanzar en los sentidos de este cambio, en el próximo capítulo interesa problematizar una serie de conceptos usuales en el estudio de estos temas y presentar la renovación teórica sugerida, no al modo de un marco teórico general que explicaría el caso, sino como una orientación, que ayuda tanto a construir la especificidad de lo que está en juego como a orientar el análisis del material obtenido en el campo.

\footnotetext{
12 Para Raymond Williams (2000: 146) las definiciones de lo emergente sólo pueden producirse en
} relación con un sentido cabal de lo dominante. 


\section{Articulaciones entre la sociedad y la música}

¿Cómo trabajar empírica y analíticamente con fenómenos musicales donde ya no resulta tan claro dónde empieza y dónde termina la "obra" musical? ¿De qué manera se pueden abordar músicas en las que las tecnologías han habilitado nuevas sonoridades, conexiones con otras manifestaciones estéticas y posibilidades de producción relativamente fáciles y baratas? En este contexto, ¿qué decir de escenas donde los músicos no se distinguen de forma taxativa de los públicos? ¿Con qué categorías pensar músicos que asumen una variedad de prácticas impensadas o invisibilizadas décadas atrás, veladas bajo el magnetismo de la obra? ¿Cómo, a su vez, interpretar el protagonismo y la actividad de los escuchas? En definitiva, ¿qué es la música y quiénes son los músicos en estos contextos? Para poder empezar a responder estos interrogantes se vuelve necesario realizar un recorrido por ciertos puntos clave de algunos autores y tradiciones que se han propuesto pensar el vínculo entre la música y la sociedad.

Tradicionalmente, la sociología ha planteado la relación entre la música y la sociedad a la manera de una asociación mecánica entre una serie de obras, géneros y/o estilos musicales, por un lado, con una serie de grupos, estratos o clases sociales, por el otro. Frente a una teoría estética que plantea la autonomía inverosímil del sujeto del gusto y sostiene la existencia del objeto musical sin necesidad de referirlo a la sociedad, la sociología vuelve al arte creencia, planteando una relación cuyos productos son simultáneamente el objeto artístico y su admirador. Así, frente a los esteticismos, las ciencias sociales han construido sociologismos de variado calibre, según la oposición que presenta Hennion (2002). En el intento de desligarse de la ponderación normativa de los esteticismos, como también del estatuto de excepción que otorgan al objeto y a la experiencia artística, la sociología de la música se ha reducido al análisis de la producción y recepción de la música considerada como objeto, para disolverla en un

juego social, ya sea de la distinción, la identidad o la lucha de clases. Fascinada por su propia iconoclasia, esta sociología pierde de vista casi completamente la singularidad de lo que pretende estudiar, operando lo que Hennion (2002: 57) llama "un despoblamiento del mundo de la música", convertido en traducción transparente del mundo social y equiparado, en un gesto destructor, a cualquier otra actividad o práctica. Esta sociología -especialmente la de los discípulos bourdieanos- pierde de vista casi completamente la 
singularidad de su objeto, y como dice de Singly (2006: 42) considera a fin de cuentas que "beber un vaso de tal aperitivo es equivalente a escuchar tal fragmento de música clásica".

En una propuesta de superación de estos dos polos de interpretación reduccionistas de la relación entre la música y la sociedad, Hennion (2002: 290) recupera para el análisis las mediaciones, los mixtos de los que está colmada la música. Refiere a una red diversificada de objetos técnicos, soportes materiales, instrumentos, dispositivos, escritos, sobre los que el músico debe operar para que finalmente emerja la música como tal. La música, entonces, ya debe concebirse en sí misma como una sociedad plena de mediaciones que la hacen aparecer. Mismo DeNora (2000 2012) considera a la música un ingrediente activo de la formación social y un recurso, al contrario de lo que usualmente se supone, incapaz de trabajar separado de sus circunstancias de producción. Contra las interpretaciones sociologistas que no pueden desprender la capacidad interpeladora y productiva de lo sonoro de la noción de consumo distintivo, usos desviados o identidades sociales, DeNora afirma que la música es un dispositivo habilitante de una multiplicidad de usos. Nuevamente, no es la música como objeto sino la música como relación performativa lo que DeNora significa cuando la refiere como habilitación.

Como se desplegará en las páginas siguientes, la conjunción de estos dos autores supone un contrapunto que relocaliza un problema clásico de la tradición sociológica, el del agente y el sistema, en nuevos términos y en nuevas relaciones. Los desarrollos de Hennion re-dimensionan el concepto de campo, mientras que los planteos de DeNora amplían las dimensiones de la agencia ${ }^{13}$ en la música, superando las formulaciones subculturalistas. De esta manera, para un análisis de las formas emergentes de lo musical, permiten operar con mayor precisión de la que admiten categorías como subcultura, identidad y campo, habida cuenta de que estas últimas representan los modos de abordaje más corrientes en los estudios sociales de la música.

\footnotetext{
13 Retomo de Ortner (1999) un concepto de agencia que trata de conjugar dos enfoques: el énfasis geertziano en la cultura y el sentido que enfatiza el poder y su efecto en los actores. En el primer caso, la agencia refiere a un actor comprometido en un proyecto, un juego o un drama, un actor que no posee sólo un "punto de vista" sino una proyección más activa de sí hacia algún fin deseado. Este actor, entonces, más que un mero ocupante de posiciones específicas y más que un simple poseedor de determinada identidad, es un actor que porta una subjetividad cultural e histórica (Ortner 2005). En el segundo contexto, la agencia es aquello hecho o negado, expandido o contraído, en el ejercicio del poder. Es una (sensación de) autoridad para actuar, o de falta de autoridad y de empoderamiento. Enmarcada en las cuestiones de poder, la agencia representa la vivencia subjetiva de autorización, control y efectividad en el mundo.
} 


\section{La música como una sociedad plena de mediaciones}

Las formulaciones deudoras de Bourdieu reconocen un espacio social específico donde se despliega la producción de bienes musicales: el campo musical en su conjunto o el campo correspondiente a un tipo específico de música, clasificada por un género musical, por un estilo y/o por modos técnicos de producción, entre otros criterios. El uso de esta noción implica otorgar una autonomía relativa a las prácticas musicales en un espacio que por otra parte no es neutro sino que está estructurado como un sistema de relaciones de competencia y conflicto entre agentes y sistemas de agentes situados diferencialmente. Estos agentes comparten cierto habitus y están investidos de una illusio (interés) al respecto de lo que está en juego en dicho espacio (Bourdieu 1983). Producto de la pregnancia de los planteos de Bourdieu en las ciencias sociales argentinas, varios trabajos han pensando los fenómenos musicales desde esta perspectiva. En lo que respecta a la temática en estudio, Vecino (2011) propone que la producción de la música independiente en la ciudad de Buenos Aires se constituye como un subcampo de producción restringida donde se produce objetivamente sólo para productores (actuales o potenciales) que son al mismo tiempo, tal como lo plantea Bourdieu (2010: 90) clientes privilegiados y competidores. Sostiene, asimismo, que esta configuración particular se vincula a las transformaciones que las nuevas tecnologías producen en el régimen de producción, circulación y apropiación de la música. Se desarrolla así una fracción heterodoxa que se autonomiza y se sustrae a los criterios de producción de la gran industria, desplegando una lógica de producción propia.

Con esta conceptualización del "campo de producción restringida" Bourdieu intenta dar cuenta para el caso de Francia de un tipo de realidad bastante diferente a la que acá se presenta, donde un círculo de vanguardia se constituye en una instancia de elaboración simbólica con lógicas propias, que luego irradian hacia el gran campo de producción cultural. De esta manera, aunque el mundo musical emergente que acá se analiza resulte en buena medida una "sociedad de admiración mutua" (Bourdieu 2010: 91) y organice narrativas alrededor de una oposición con el mercado, no se constituye exactamente en una fracción vanguardista que disputa la legitimidad dominante a partir de la clásica idea de la pureza de un arte cada vez más separado de un público no entendido o no profesional. Estos actores, en realidad, estructuran otros modos de legitimación, basados en una lógica de producción propia, y no otros criterios al interior de un campo de la música relativamente unificado, compuesto por el campo de 
producción restringida y el gran campo de la producción simbólica, destinada al gran público (es decir, lo que estos músicos llaman "mainstream", en una construcción "nativa" que debería densificarse para cada caso y no tomarse como un circuito musical aparentemente establecido, mero dato determinado por la tradición). Para estos músicos, por el momento, la disputa se ha resuelto con un cambio de escenario y no jugando el juego al interior de un campo musical que, por otra parte, no puede a esta altura afirmarse sin conflictos. En este sentido, y en un argumento complementario, lo que se estudia aquí no se inscribe sólo en un campo estético, como pretende la mirada de Bourdieu con el concepto de subcampo, sino que tiene existencia también en el ámbito del trabajo y en los lugares y círculos de sociabilidad que la práctica de hacer música crea y/o habilita.

Justamente, en relación a la noción de campo, en un diálogo al respecto de las nuevas prácticas culturales de la juventud en España y en México, Canclini y Cruces (2012) sugieren que las manifestaciones artísticas juveniles que analizan (edición de libros y discos, eventos musicales, arte visual, etc.) romperían con el uso convencional de este concepto, tal como ha cristalizado en las ciencias sociales. Para ellos hablar de campo literario, campo musical o campo artístico (en un sentido asociado a las bellas artes) resulta inadecuado para mundos de la práctica donde las personas no se califican en una sola disciplina, sino que circulan entre ellas y las fusionan, buscando otras maneras de producir. Por lo tanto, proponen de manera pragmática la pertinencia de la noción de redes, sin preguntarse, no obstante, por la vigencia de la categoría de campo para pensar las prácticas que estudian.

Desde el vocabulario teórico de Bourdieu, es posible interpretar que el mundo de la práctica musical y estética estudiado en esta tesis opera nuevas dimensiones y fragmentaciones al interior del campo de la música, como también aperturas a otros campos (de la literatura, de las artes visuales, del diseño, etc.), dadas en parte por el cambio tecnológico que permite la puesta en práctica de conexiones antes impensadas. A su vez, la multiplicación de las legitimidades que implican estas prácticas (que no siempre son microlegitimidades) puede atentar contra la noción de campo mismo, en tanto este es definido como un espacio donde se apuesta por el monopolio de un capital específico legítimo y en cuanto se asume que ese capital tiene una lógica y una consistencia que no tendría actualmente. Los avances de investigación, entonces, habilitan la pregunta por la existencia de una lógica de la estructuración de los campos 
distinta a la que propone Bourdieu, e incluso por la vigencia de esta categoría misma para el estudio de la música como organización social.

$\mathrm{Al}$ respecto de este problema, es necesario preguntarse si no se asiste hoy en el mundo de la música a una situación similar a la que documenta y analiza el propio Bourdieu (2000 [1982]) para el caso del campo religioso, cuando contrasta y revisa su propia teorización previa, de inicios de la década del 70 (Bourdieu 2006 [1971]). Se trata del problema de los estados históricos de un campo, donde sus fronteras (y por lo tanto, las que guarda otros campos) también se plantean como un producto de la historia. En el caso de lo religioso, Bourdieu sostiene que ya no habría límites precisos, claros, tajantes, entre "el reino de los clérigos" y otros campos, en particular el de la medicina y el de la psicología, que hacia comienzos de los ochenta ya disputaban claramente con la religión la cura de los cuerpos y de las almas en el marco de una redefinición de la división y oposición binaria entre estas categorías.

En el caso empírico del que parte esta tesis, la incorporación por parte de los músicos de la necesidad de encarar de manera activa y diferente las relaciones con el mercado, es decir en la centralidad que adquiere para ellos la gestión (como en su reivindicación de dicha necesidad) es posible entender un cambio en lo que se considera que debe ser un músico. Este proceso, del cual esta investigación es contemporánea, va acompañado de prácticas habilitadas por nuevas tecnologías, ahora mucho más accesibles al gran público, que permiten una relación diferente con los medios de producción y reproducción de música: desde grabar en la propia casa hasta utilizar la música previa como dato a ser intervenido y no sólo a ser reproducido. Asimismo, la producción y la presentación de música no se encuentra en estos casos separada de las artes visuales, plásticas y escénicas, en muchos casos realizadas por las mismas personas. En estos mundos musicales es usual encontrarse con creadores que mezclan en directo loops de vídeo e imágenes mientras toca la banda (generalmente llamados "VJs", del inglés videojockey ${ }^{14}$ ), con músicos que realizan el arte de tapa de sus propios discos (e incluso que los producen materialmente ellos mismos, uno por uno), con eventos donde la música en vivo es acompañada de pintadas de paredes o murales, recitadas de poesía y hasta cortes de pelo. En este marco, a nivel de las trayectorias personales, se trata de músicos que tienen formaciones y orientaciones artísticas que

\footnotetext{
${ }^{14}$ En algunos casos, los Vjs son miembros plenos de la banda, en otros se presentan públicamente a menudo con ella, pudiendo existir encuentros previos en los que el creador visual negocia con la banda la estética y el contenido específico de su puesta.
} 
exceden la música. En este punto, la construcción de un mundo prosumidor altera no solamente la categoría de los bienes sino también las relaciones entre las personas que consumen/producen esos bienes. De esta manera, nuevamente en un lenguaje bourdieano, lo que cambia es la dinámica de producción de campos y no sólo su frontera.

La dificultad de establecer los límites de la música, de ceñir el fenómeno musical en estudio a la fijeza del concepto de campo tal como ha cristalizado, aparece en general en la descripción del patrón de producción que resulta núcleo de esta tesis. En tanto los análisis bourdieanos tienden a estructurar el análisis de las prácticas estéticas de una forma legitimista o dominocéntrica (Grignon y Passeron,1991), la vocación desromantizadora originaria de Bourdieu al respecto de la estética pura se ve subvertida en la identificación del análisis con los criterios de la cultura dominante (ya que, al descubrir el arte como creencia y dominación simbólica, se dificulta reconocer las prácticas más que ubicadas de mejor o peor manera en relación con la legitimidad). En este punto, ante la concepción petrificada del campo, que naturaliza las divisiones sociales, y por lo tanto, en lugar de ver el arte como hecho social -en su constitución misma-, lo concibe como obra, como un objeto dado (y ya dado por la definición dominante) es iluminador volver a la noción de mundo de arte de Becker (2008), quien devuelve a los objetos de la vida estética su carácter de objetos sociales.

El planteo beckeriano supone que el arte no es un objeto que el sociólogo pueda definir sin atender a la red de relaciones en que ese objeto surge. Más bien, el arte para Becker es el producto del trabajo de una red de cooperación organizada convencionalmente para producir obras/productos que el grupo en análisis define como artísticos. Teniendo en cuenta que en el patrón de producción musical emergente la primacía es de la música pero su estudio ya no puede reducirse a los específicos espacios y momentos donde de hecho se produce música en su sentido sonoro convencional (emplazando la observación en los recitales, los ensayos y otros momentos de aparición de la música) utilicé la noción de mundo de arte a modo de una orientación metodológica. Así pude considerar para la observación participante y el análisis la relevancia (y, a veces, el carácter constitutivo) de ciertas prácticas de sociabilidad grupales que si bien un observador externo separaría de dicho patrón son, sin embargo, constitutivas del mismo. En otras palabras, rastrear la red (en el sentido de 
Latour 2008) ${ }^{15}$ que hacía aparecer la música volvió necesario el acceso a una amplia variedad de prácticas cotidianas de estos actores. En el mismo sentido, en una discusión con la estática noción de gusto de Bourdieu (1998), reducida a la correspondencia con una posición en el espacio social, Hennion (2012) plantea que los festivales, las danzas, las drogas y estimulantes, la ropa, las relaciones sexuales, entre otras prácticas, definen las condiciones del gusto musical en la actualidad, por lo que no es posible disociarlas del estudio de la música.

Análogamente al camino que Bourdieu emprende críticamente contra sí mismo en el ya citado artículo "La disolución de lo religioso", es posible pensar que el desmoronamiento de la frontera del campo musical se vincula, justamente, con los cambios en la definición misma del músico y de la música. Es decir, al distinguir un nuevo estado del campo religioso, Bourdieu realiza de forma indirecta una reflexión sobre el propio concepto de campo y de cómo muchas veces el uso de esta noción naturaliza lo que son más bien sus estados históricos. En este sentido, de la misma manera que la religión ya no se puede definir más por la cura de almas (lo que suponía una división cuerpo/alma que dejó de existir de la misma manera), ciertas músicas ya no pueden pensarse a partir de las ideas de obra, artista y público (o escuchas). Es decir, las prácticas y agentes específicos de un campo en un momento particular de su desarrollo producen una forma particular de practicar y entender la música, definiendo sus propios límites y su sistema de relaciones internas. En su aparente sencillez, la noción beckeriana de mundo del arte ya suponía este argumento, al considerar que la trama organizativa creadora de arte es también productora de la legitimidad de los criterios estéticos (y, por lo tanto, de la distinción entre qué es arte y qué no lo es). Esa intuición a la que ciertos usos de Bourdieu no permiten permanecer fieles, sí es acompañada y profundizada en la interpretación de Hennion (2002 2012), que por un lado atiende la red social, y por el otro, a diferencia de Becker, no ignora las relaciones de dominación propias de esas redes sociales.

El planteo de Hennion intenta retener la dimensión de flujo social en la constitución de la música donde intervienen no sólo actores sino también objetos de capas múltiples, que agregan multiplicidad al fenómeno (Latour 2008: 209),

\footnotetext{
${ }^{15}$ Con esto refiero a que he orientado mi trabajo a describir las distintas actividades, objetos, categorías, narrativas y actores que hacían aparecer la música en mi campo. Rastrear la red no implica entonces describir una red (o actores relacionados bajo la forma de una red) sino concebir el método de construcción del objeto a partir de esa forma (Latour 2005: 207).
} 
configurándose una red de actantes ${ }^{16}$. Considera que no hay que tomar la música como un objeto de buenas a primeras porque esta es en sí misma un evento donde no es posible disociar la música propiamente dicha de sus mediaciones: instituciones, objetos técnicos, soportes materiales, instrumentos, etc. Como se presentó al comienzo de este capítulo, la música para Hennion es el resultado de estas mediaciones, o más bien, la música es la relación de mediación misma. Es decir, la música es en sí misma una relación social, un hacer inextricablemente ligado con prácticas que no son musicales en un sentido estricto sonoro y con tecnologías y dispositivos que imprimen su huella en la música que se produce. Por ello, la música ya es en sí misma sociedad y no una metáfora, reflejo o expresión de lo social. En realidad, la relación de constitución recíproca entre música y sociedad no es una novedad imputable a Hennion: como se verá en el siguiente apartado, la crítica al subculturalismo también avanza en esta dirección, pero mientras esta enfatiza el carácter de esferas relativamente incompletas de música y sociedad que se interpenetran, la posición de Hennion es más radical al entender a la música directamente como una red de mediaciones eficaces que la producen.

En este contexto, la noción de mediación supone una operación activa, productora, inseparable de los objetos, asignable a actores que deben ser identificados por el análisis. Se considera entonces que para la música emergente contemporánea el sello es una institución mediadora fundamental. En este sentido, surge la pregunta al respecto de qué es lo que esa mediación está actualmente permitiendo hacer en la música emergente, es decir, qué cursos de acción habilita. Empíricamente, se trata de operacionalizar la noción de mundo del arte, sirviéndome de sus componentes sensiblemente situacionales y procesuales, para estudiar la música de manera ligada a una forma de instituirla y de practicarla, la forma sello.

\footnotetext{
${ }^{16}$ La noción de actante en la sociología de Latour (la cual retomo en este caso de la reconstrucción de Nardacchione 2011: 178) reemplaza a la noción de actor, introduciendo al menos dos novedades. Primero, el actante se integra a una trama narrativa dentro de la cual cobra sentido su acción. Segundo, actante puede referir a una gran cantidad de entidades: una persona, un colectivo, una organización, un objeto, un relato, etc. Todos estos usos del término comparten una distancia con la clásica carnadura subjetiva (heredera de una filosofía de la conciencia) a través de la cual ha sido usada la noción de actor.
} 


\section{La música como habilitación de una pluralidad de usos}

En el marco de los planteos ocupados en pensar la articulación entre música y sociedad, el subculturalismo se proyecta como una tradición muy fuerte. Dentro de los estudios culturales ingleses, este grupo de investigadores abocado a estudiar subculturas jóvenes de clase trabajadora, puso el foco en el problema de la diferenciación social a partir de un principio de estilización. Esta tradición se centra en mostrar cómo las diferentes subculturas juveniles identificadas -comúnmente de forma espectacular- por sus posesiones, escuchas musicales y objetos, construyen un estilo a partir de esas apropiaciones: no se trata de meras cosas tomadas (o escuchadas). La estilización implica una organización activa de objetos ofrecidos por el mercado (vestimenta, música, accesorios, etc.) en una coherente y distintiva manera de "ser en el mundo". Se trata del uso de objetos particulares que podían ser hechos homólogos a los intereses grupales, sus actividades, su estructura misma de grupo y su autoimagen colectiva (Hall y Jefferson 2010). Resituar y recontextualizar las mercancías abría la posibilidad de subvertir sus usos convencionales, pudiendo encontrarse lecturas nuevas y encubiertamente opositoras de los artículos más estandarizados. Usos irónicos y sacrílegos de artefactos "sagrados", usos "incorrectos" del lenguaje, en fin, usos "ilegítimos" de los objetos que convivían con sus usos "legítimos" y convencionales (Hebdige 2002). A partir de estas orientaciones, los subculturalistas se proponían examinar concretamente y en profundidad una región de la cultura contemporánea, que debía ser entendida en su completa especificidad, para luego indagar cómo podría estar conectada a estructuras culturales y sociales más amplias (Hall y Jefferson 2010).

En cuanto a la música, la forma subculturalista de concebir las membresías musicales ha sido muy criticada: no puede dar cuenta de la fluidez en la que se coproducen la música y las categorías sociales (clases, grupos, “jóvenes”, etc.) ya que supone relaciones de necesidad en la conexión entre ciertos estilos musicales y ciertos actores sociales, además de que es incluso inflexible para reconocer las variaciones al interior de las subculturas. Aún cuando el subculturalismo fue criticado en sus fundamentos (en el contexto local de forma pionera por Vila 1996), el planteo generalizado en los estudios sociales de la música que parte de estudiar un género (o estilo) musical en relación a una clase social (o fracciones de la misma) implica una fuerte orientación hacia esa tradición, perdiendo incluso muchas veces la fuerte densidad y riqueza con que los estudios originarios trataban la experiencia de clase. 
En la academia local, las formulaciones subculturalistas se han utilizado para entender la práctica musical a partir de su oferta de mensajes para la conformación de identidades de grupos previamente definidos. Es paradigmático en este sentido el trabajo pionero de Vila (1985) sobre el rock nacional, donde se muestra cómo los "jóvenes" utilizaron una música, el "rock", en la construcción de un movimiento social anti-dictatorial. Vila propone al rock nacional como ámbito de constitución de un nosotros, introduciendo la noción de una música de uso (Vila 1987a). Como el tango y el folclore en su momento, el rock nacional fue propuesto por su análisis como un movimiento social en el que podemos identificar a un actor social específico que, entre otras cosas, usa esa música como soporte de su identidad. Años después Vila (1996) admitió cómo dibujó con trazos muy gruesos los actores sociales, adscribiéndoles ciertos intereses ligados a su posición social y relacionándolos con ciertas expresiones musicales bien definidas que, se asume, los representaban, dada la homología estructural hipotetizada. En la identificación de los jóvenes con lo rockero se perdía de vista la heterogeneidad de las adscripciones musicales: considerando que el movimiento social del rock es caracterizado como policlasista (Vila 1985: 145), entre diferentes fracciones de las clases medias y sectores populares (o "la gente de los suburbios", Vila 1985: 143), el análisis afirmaría que todos los jóvenes de esas clases son rockeros. Asimismo, estos jóvenes aparecían clasificados en distintos grupos dentro del movimiento en homologías con su posición social ("la gente de los suburbios" con el rock pesado, la clase media baja y media con el "rock nacional", la clase media con el punk). En ese argumento se ignoraba que estos estilos no eran igualmente antidictatoriales ni se correspondían unívocamente con esos sectores sociales.

Es en la crítica a esta construcción analítica que Vila (1996) introduce la cuestión de las identificaciones plurales para una misma música. Paralelamente a su apropiación de los planteos de Frith (2003) contra el mecanicismo del argumento homológico ${ }^{17}$, se propagan con fuerza en el contexto argentino unos estudios que ponen el foco en la práctica musical entendida como una arena para la construcción de sentido (con especial interés en los que podían ser considerados desviados y resistentes) por

${ }^{17}$ Frith (2003) se corre del supuesto de que existe un grupo ya constituido que luego se expresa en sus actividades culturales: no es que un grupo social tiene creencias luego articuladas en su música, sino que la música como práctica articula en sí 'misma un proceso tanto social como estético, una comprensión tanto de las relaciones grupales como de las individuales. Partiendo del supuesto de que la música es muy poderosa en su capacidad interpeladora, ya que trabaja con experiencias emocionales particularmente intensas, Frith considera que las personas gozan de la música popular porque esta da respuesta a cuestiones de identidad (Vila, 1996). De esta manera, su propuesta renunciaba a pensar la música sólo en tanto medio expresivo para abrir la posibilidad de su imbricación en el sujeto mismo. 
parte de grupos sociales, casi siempre juveniles. La música aquí se define por su uso en una valencia específica: ofreciendo distintos mensajes con los cuales las personas pueden resolver cuestiones identitarias. En esta línea, ya sea desde un abordaje de la producción de identidad o de la construcción de identificaciones, muchos trabajos se dedicaron a considerar a la luz de la historia argentina reciente las prácticas de consumo, interpretación y circulación de determinadas expresiones musicales especialmente de aquellas que se consideraban centrales en la experiencia de los sectores populares: la cumbia y el rock chabón o barrial (Elbaum 1994; Semán y Vila 1999 2006; Cragnolini 2006; Míguez 2006; Semán 2006; Alabarces et al 2008; Benedetti 2008; Garriga Zucal 2008; Martín 2008; Silba y Spataro, 2008). En estos trabajos, el interés en los fans, los seguidores, los escuchas, obedecía en parte a la tesis de que, a la luz de la reestructuración social neoliberal, las narrativas identitarias especialmente las juveniles- se construían más bien en torno a prácticas culturales y repertorios simbólicos ofrecidos desde las industrias culturales antes que a través de instancias socializadoras clásicas como la familia, los partidos políticos, el trabajo, los sindicatos y la educación (Svampa 2005).

Muchos de estos trabajos, sin embargo, reprodujeron cierto mecanicismo en el análisis de la relación entre música e identidad, cuando ya la crítica de Vila (1996) a su análisis del rock como movimiento social aglutinante y productor de una identidad juvenil anti dictatorial había cuestionado los supuestos de una lógica de la identidad plena. Más recientemente, algunos autores han planteado que las nociones de identidad y de identificación comprimen las razones por las que se supone que un "joven" se aproxima a la música (Gallo, Garriga, Semán y Spataro 2011). Esta autocrítica lee en la producción local una reducción de la agencia estética a la capacidad cognitiva o interpretativa de los "oyentes", que se limitan a dar sentido a los productos musicales que se les ofrecen. Pero: ¿cuántas cosas pueden hacerse con objetos (incluyendo sonidos), y de hecho se hacen, además de producir identidades e identificaciones? En convergencia con estudios que han planteado una ampliación e individualización del menú musical habilitado por las nuevas tecnologías (Semán y Vila 2008), se ha avanzado hacia la ampliación del concepto de uso en la música para entenderlo no sólo en sus dimensiones identitarias o bien como subversión o desvío frente a las prescripciones convencionales, sino como un concepto que se desplaza del plano de la apropiación al plano de la acción social misma. 
El procesamiento de la edad y la conformación de subjetividades femeninas en el caso de las fans de Ricardo Arjona (Spataro 2012), la forma de comunicación a partir de lo corporal y las relaciones físicas en el baile electrónico en relación a la articulación moral que lo acompaña (Gallo 2011b), las formas en que la música produce profesión en un colectivo de Dj's (Irisarri 2011), las normatividades en el baile en relación con las prácticas íntimas en ámbitos propios del tango milonguero y las milongas (Carozzi 2009 2011), el trazado de trayectorias morales a partir de la pasión por la ópera (Benzecry 2012), la formación de los cuerpos y las subjetividades en el marco del baile del cuarteto y la pista electrónica (Blázquez 20082009 2011) son algunos de los estudios donde el uso de la música encuentra una radicalidad, refiere al sujeto mismo, a la vez que restituye las dimensiones del cuerpo, los sentimientos, la moralidad, los proyectos, las carreras, a la problemática de la agencia estética, restringida muchas veces en la bibliografía a los aspectos de la interpretación de un mensaje por parte de un oyente.

Es el planteo de DeNora (2000 2012) en el campo de la sociología de la música el que permite entender el giro señalado. DeNora (2000) relee los materiales etnográficos de algunos investigadores subculturalistas, desligándolos del marco homológico y de la pretensión totalizadora de los estudios culturales, para entenderlos dentro de una teoría de la música como acción. Retoma a los bikeboys, informantes de Willis (1978), para plantear cómo la música tiene el poder de llevar a las personas de un estado a otro. Volviendo sobre las palabras de uno de los muchachos de Willis: "if you hear a fast record you've got to get up and do something, I think. If you can't dance any more, or if the dance is over, you've got to go for a burn-up [motorcycle ryde]" (Willis 1978: 72, citado en DeNora 2000: 7) argumenta que la música es un vehículo cultural, que puede ser montado como una moto o abordado como un tren. De esta manera, para DeNora uno de los más llamativos y pioneros aspectos de la obra de Willis, generalmente subestimado, es su concepción de la música como un recurso activo de la formación social y no como algo que se relaciona con ella, como mero medio "significante" o "expresivo". Gallo et al (2011: 23) construyen un caso basado en la bibliografía especializada para ejemplificar esta diferencia: una cosa es que una letra de música popular sea interpretada en un sentido místico, otra es que "al oírla, se viva esa canción (que no era para nada mística) como una forma de oración (supongamos el caso de un joven practicante zen que tiene en un determinado rap la perfecta articulación rítmica para finalizar su práctica diaria).” 
Es en esta dirección que para DeNora la música debe entenderse como acción: como práctica y como proveedora de una base para la práctica. En este sentido, la categoría de habilitación (la affordance ${ }^{18}$ ) aborda la música como medio formativo en relación con la conciencia y la acción, como recurso (más que como medio) para la construcción y proyección del mundo. Entonces, hablar de la música como un dispositivo habilitante significa decir que la música es algo con lo que se actúa y sobre lo que se actúa. El foco nuevamente se aleja de lo que la música describe o de lo que puede leerse en la música sobre la sociedad, para acercarse a aquello que la música posibilita, es decir habilita como un proceso social en sí mismo. De esta manera, se pone de relieve el potencial de la música como medio organizador, como algo que contribuye a estructurar los estilos de conciencia, las ideas, los proyectos. Para DeNora, como para Hennion, la música es constitutiva de la vida social: su despliegue como acontecimiento tecnológico, que toma cuerpo en una performance, requiere su conceptualización como una acción social en sí misma.

En definitiva, mientras en los planteos bourdieanos y subculturalistas lo social aparece penetrando, produciendo o contexualizando la música, en los enfoques de Hennion y de DeNora la relación entre la música y la sociedad no es de exterioridad, sino de imbricación. No debe ir a buscarse lo social en la música (convirtiendo a esta en un reflejo, una expresión, una metáfora, una manera de manifestación de lo social) porque la música ya es social y produce sociedad por sí misma. Específicamente, con respecto al caso que en esta tesis se analiza, como ya ha sido planteado en Gallo, Garriga, Semán y Spataro (2001), Hennion permite detectar una nueva sociabilidad musical, mientras DeNora captar una nueva agentividad en el uso de la música, es decir, una pluralidad de usos, ampliando esta categoría y enriqueciendo a su vez la de agencia. A partir de la conjunción de estos dos aportes, es posible preguntarse por la habilitación de proyectos musicales de nuevo tipo a partir de instituciones musicales, las cuales constituyen en sí mismas la música que se produce. Instituciones como los sellos que, si bien no son enteramente nuevas, se configuran para los sujetos de la generación en análisis de un modo distinto, y como sostendré, novedoso, permitiendo otro tipo de relación con la música y con los medios de producción de música, asumiendo a la vez otro significado para los actores.

18 Derivado del verbo to afford (que podría traducirse como habilitar), este concepto invita a pensar aquello que permite (y que no permite) un objeto, o dicho más estrictamente, los cursos de acción, las maneras de ser, de hacer y de sentir, que un objeto en el proceso de su apropiación habilita. 


\section{Una nueva música de uso}

Originalmente, la idea de una música de uso (Vila 1985 1987a 1989) permitió pensar la existencia de una música representativa de una época, y de un sector social, en el caso del rock, la juventud, entendida en estos trabajos a la manera de una combinación de un rasgo etario con una configuración socio cultural que la instituye como un actor socio-culturalmente relevante. Esta noción de música de uso estaba pensada desde las categorías de identidad, de movimiento social y de género musical: se trataba de una asociación analítica que suponía un uso de la música basado en la identificación, que esperaba una perspectiva de actuación política para una comunidad interpretativa (Gallo et al 2011) y que englobaba bajo el género del rock músicas que luego de la reapertura democrática se fragmentarían en multitud de géneros específicos (Alabarces et al 2008), mostrando el carácter contingente e histórico de estas construcciones generalmente naturalizadas. Esta pauta exclusivista, única y homogénea en la relación de los sujetos con la música (Semán y Vila 2008) no puede predicarse luego de esa fragmentación (quizás nunca haya sido posible, pero los análisis estaban justamente limitados por la particularidad histórica del movimiento del rock en la conformación de fuertes identidades colectivas). Es por ello que, en los últimos años, en el marco de transformaciones estructurales de la sociedad argentina que le otorgan un papel más central a las industrias culturales, los espectáculos y el tiempo libre, incrementando la auralidad (Yúdice 2007), la expansión de diversas categorías de música de uso es planteada por la bibliografía especializada (por ejemplo Semán y Vila (2011: 37) para el caso de la cumbia villera; Gallo (2011) para el caso del dance).

Como ya fue referido, las críticas a la forma taxativa en que se vinculó el uso de la música con la identidad fueron abriendo progresivamente un espacio para pensar otros usos de la música. Así, los estudios sobre nuevas músicas de uso ya no se centran en las cuestiones de identidad e identificación: se han revisado a sí mismos como tradición, al mismo tiempo que se hacen cargo de prácticas musicales que diversificaron sus posibilidades de uso. Como se verá más adelante en la descripción de un sello particular asociado a la música indie, el indie en sí mismo es un criterio de producción y consumo estético que asume la erosión de los géneros musicales (ya planteado para otros contextos: Ochoa 2003; Semán y Vila 2008; Gallo 2011), la "relajación” y, en 
general, la onmivoridad y el gusto por lo inclasificable. Esto, junto a la conjunción ya señalada de la música con otras artes -en su presentación pública pero también en su elaboración- refuerza la interpretación de que la mezcla (Gallo y Semán 2013) es un criterio de producción en la música juvenil contemporánea. A este respecto, Vila (1987b: 24) ha planteado que la mezcla es una característica del rock nacional clásico, tanto como del folclore y del tango, diferenciándose en el contenido de dicha mezcla. De acuerdo a su interpretación, en distintos momentos de su historia y de manera variable, el rock nacional se ha relacionado con el rock and roll, el blues, el pop, el rock sinfónico, el punk, el jazz, la new wave, el reggae, el ska, el rockabilly, la música clásica, la bossa nova, el tango, etc. El criterio de esta mezcla tal como la entiende Vila es la fusión, donde los géneros continúan claramente delimitados. Por el contrario, la mezcla tal como se la comprende y practica en el indie, y en otras manifestaciones musicales y estéticas contemporáneas, apela a la de-construcción de los géneros, su puesta en contradicción hasta el estallido, reforzada por la amplitud de lo que se pone en contacto luego de que se ha producido una apertura estética a lo antes rechazado (observada de forma paradigmática en el acercamiento del rock a la cumbia y a la llamada "música comercial").

Esta sensibilidad, más flexible y cambiante (a diferencia de las identidades juveniles moldeadas por los estudios anteriormente citados) es importante y será objeto de análisis, pero más relevante - a la vez que generalizado- es el marco de acción que la generación de músicos emergentes que analizo comparten. La aparición de una creciente cantidad de agrupaciones musicales que son capaces de prolongar una apuesta estética en el tiempo, de combinarla con alguna compensación económica, de influir en una dinámica de creación de públicos, por su parte muy activos y, en definitiva, de crear un espacio social articulado alrededor de la música (Gallo y Semán 2013) nos habla de un movimiento emergente en la música juvenil que no existía en la época del imperio de las discográficas.

Así, de la misma manera que en 1985 Vila describió el espacio del recital y su funcionamiento como refugio frente a la política del Proceso, habilitando una lectura acerca de la organización de una sociabilidad joven a partir de una música (en un marco de desarticulación colectiva y restricción feroz de la oportunidad de estar con otros), hoy puede describirse a los sellos y a otras instituciones a pequeña escala que hacen música como los espacios contemporáneos por excelencia donde se materializa una sociabilidad musical. Puede pensarse que en estos espacios la música es una relación 
social que en su propia actualización amplía las posiciones en las cuales es posible participar de la música, y por lo tanto, volverla acción social, especialmente a partir de la extensión de la agencia estética que traen las nuevas tecnologías. Así, debe entenderse que para los participantes de estos mundos musicales la música no es algo que meramente se escucha sino que es una práctica en la cual están comprometidos, es la consecuencia de una acción definida de forma singular, a la vez que un recurso para relacionarse con otros y crear lazos, relaciones e instituciones.

De esta manera, entendiendo a la música como relación social -creadora de sociabilidad y organización social- los usos de la música relevantes a esta tesis se asientan en el terreno de la producción musical, además de aparecer respondiendo a cuestiones identitarias y de sensibilidad. Se activa en los sellos y otros colectivos musicales de su clase una nueva forma de producir música y de relacionarse con los medios de producción de música, es decir, una manera novedosa y generalizada de uso de la música ampliado y pluralizado por las nuevas tecnologías. Asimismo, en el marco de estas relaciones, la música no puede ser más que el resultado de un agenciamiento con música, por lo que su uso se imbrica en dimensiones constitutivas de la subjetividad. Sintetizando, a partir del análisis empírico de este campo, puede pensarse una nueva música de uso a partir de las dimensiones generalizadas de un tipo de relación con la música y sus medios de producción y un tipo de agenciamiento con música. 


\section{De la escena al sello: el proceso de construcción del objeto}

En un primer momento, el trabajo de campo realizado sobre el mundo del indie de la ciudad de La Plata, se orientó hacia los artistas (los solistas y las bandas) que componían, de acuerdo a los interlocutores etnográficos, una escena. La de los músicos era una instancia evidente para mí como "joven” socializada en el rock nacional, teniendo en cuenta que la historización de esta tradición relegó a los sellos discográficos y a otras instituciones y dispositivos de mediación musical a un lugar secundario, frente a la importancia otorgada a los artistas -salvo quizás los recitales, por su importancia en nuestro país como espacio de socialización de la juventud, ya sea en la última dictadura militar (Vila 1985; Pujol 2007, entre otros) como en los períodos democráticos siguientes (un espacio de transgresión en Citro 2008 o uno de conformación de la subjetividad en Salerno y Silba 2006, entre otros).

En este contexto, organicé un primer trabajo (Boix 2011) a partir de la noción de escena: como categoría propia de los grupos analizados, al utilizarse también como categoría del análisis resultó iluminadora y relativamente fácil de operacionalizar, ya que relacionaba un estilo musical y estético específico con "un contexto cultural urbano y práctico de un código espacial” (Stahl 2004: 76). A partir de la noción de escena, el interés estaba en describir un universo de redes de cooperación que producían un mundo estético, en sus modos concretos de socialización juvenil -diurnos y nocturnos-; sus modalidades de consumo musical; sus sentidos morales y estéticos de lo que implica hacer música, en tensión con otras escenas estéticas; sus usos particulares de las tecnologías; y demás dimensiones que le daban singularidad. Asimismo, la noción permitía no inferir que entre las escenas y la estructura de grupos y relaciones sociales haya una relación fija, unívoca y de homología, como supone el concepto de subcultura, como ya se desarrolló en el apartado "Articulaciones entre la sociedad y la música".

Sin embargo, pronto la noción de escena empezó a resultar genérica y amplia. Al mismo tiempo, se fue volviendo claro en el mismo transcurrir del trabajo de campo que las bandas y los solistas no resultaban explicativos de la complejidad de la escena que se construía. De esta manera, mientras se volvía metodológicamente necesaria la elección de un contexto más acotado y localizado para realizar un trabajo en mayor profundidad, los sellos aparecían en el campo como una manera de referenciar personas, estilos y posicionamientos distintos frente a la actividad musical. Durante los años 2010 y 2011, mis interlocutores referían al sello meramente como un "paraguas" que les 
permitía agruparse. Resultaba llamativo, sin embargo, que no dejaran de adscribirse de forma permanente a un sello del que, a la vez, burlaban su importancia, sabiendo que no era lo que el sentido común esperaba que fuera. Pero varios indicios empezaron a marcar que el sello era una institución muy relevante: así, más allá de las bandas que tocaran, ciertos eventos eran referenciados como realizados por un sello y se describían grupos de afinidades entre personas a partir de los sellos. De esta manera es que el trabajo, tanto empírico como analítico, comenzó a apuntar al sello para volverlo su objeto privilegiado. Y en este proceso de comprensión de mi parte, a lo largo del trabajo de campo que continúa hasta este momento, la centralidad de los sellos fue creciendo: organización de fiestas, ciclos de recitales, festivales, veladas de lectura, y hasta la edición de discos bajo el nombre de uno o varios sellos y no de los artistas. En otras palabras, los sellos aparecen articulando de alguna manera lo que los actores llamaban escena. El sello resulta una unidad que aglutina proyectos y que permite que estos se desplieguen, como también es una unidad de referencia para los músicos y para los escuchas. El sello, entonces, se constituye como un dato a construir de un estado determinado del mundo de la música, cuya descripción debe incluir también la existencia o no de ciertos mercados, de ciertos públicos, de los dispositivos tecnológicos, etc.

A partir de una investigación con Tigra, sello vinculado la música indie, fui conociendo otros sellos de la ciudad y relacionándome con sus miembros, ya que había decidido "seguir a los actores" (Callon 1986 citado en Nardacchione 2011). Por lo tanto, si bien para esta tesis el caso de Tigra se atiende en su singularidad, en otro sentido, posible gracias al abordaje elegido, el devenir de la relación de este 'sello' con otros de La Plata, la zona metropolitana de Buenos Aires y el resto del país -reuniones entre sellos, organización conjunta de fechas, proyecciones de 'redes' de trabajo y otras actividades vistas como estratégicas- habilitó el conocimiento y el análisis de otros sellos, es decir de otros casos, que enriquecieron el análisis y la perspectiva. Justamente, en relación a otros abordajes, la perspectiva etnográfica se aproxima con ventaja si el investigador se integra en las redes de sociabilidad de los actores. Haciendo esto, fue posible posar la mirada sobre nuevos objetos empíricos y abrir nuevas dimensiones de análisis en el proceso mismo de la producción de datos.

Como será desarrollado más ampliamente en la Parte 2 de esta tesis, la bibliografía académica producida localmente sobre sellos independientes resulta muy acotada, un poco porque su historia estalla en el período que nos ocupa, otro tanto, por 
la importancia otorgada bien a los artistas, a las obras o a los públicos, descuidando el papel de las mediaciones que Hennion (2002) ha marcado como constitutivas de la música. Desde un enfoque interesado en las industrias culturales, Luchetti (2007) presenta la formación de productores fonográficos independientes en Argentina durante los últimos treinta años. Su interés está en diferenciar las características especiales de la producción fonográfica como actividad económica, sumando al análisis el tratamiento de ciertos aspectos legales del ordenamiento de la propiedad intelectual. En una tónica similar, interesado en las políticas públicas hacia el sector, Palmeiro (2005), entiende a los sellos independientes de la ciudad de Buenos Aires como pequeñas y medianas empresas (PyMEs) fonográficas, focalizando en la cadena de valor de la industria discográfica, sus participantes, costos de producción, ingresos y rentabilidad de los proyectos independientes. Desde la sociología, es el trabajo de Vecino (2011) el que da centralidad al objeto que aquí interesa construir, aún cuando su enfoque restringe la eficacia del sello al localizarlo en un subcampo de producción musical, perspectiva que se discutió en el apartado anterior. No obstante, su estudio debe ser resaltado, puesto que resulta quizás la única aproximación contemporánea al objeto sello que recupera el valor de este emprendimiento en tanto articulador de sociabilidades y en su papel de operador simbólico dentro de una oferta musical sobre saturada.

En relación al estado de las investigaciones sobre estos temas, cabe puntualizar que tomar como unidad etnográfica un sello de la clase que se describirá en el núcleo de esta tesis cuestiona una particular segmentación del análisis que el mundo del rock nacional y de otras músicas asociadas a lo juvenil había permitido: estudiar por un lado los músicos, por otro lado los públicos, por un lado la producción, por el otro la recepción, como también la separación del análisis entre las dimensiones estéticas y morales frente a las económicas. Nuestro objeto, dada sus características, requiere una mirada que integre todas estas dimensiones, y de allí la propuesta de abordaje etnográfico que se especifica a continuación.

Pensar la música como acción social y relación social, es decir como una instancia social por derecho propio, implica describir una red de intermediarios, de mediaciones -tanto de actores como de actantes-, para que finalmente sea producida, emerja ante nosotros, la música, una vez que esta ha dejado de pensarse como un objeto dado. Estas prerrogativas orientaron el trabajo a describir las distintas actividades, objetos, dispositivos, categorías, narrativas y actores que hacen aparecer la música. Rastrear la música ha implicado entonces concebir el método de construcción del objeto 
a partir de la noción de una red (Latour 2008: 207). En este contexto, hay que observar a los actores no sólo en los ámbitos que aparecen musicales por excelencia (el recital, el ensayo) sino también cuando se involucran en actos que introducen música en ámbitos extra musicales. Así, sólo en el esfuerzo de descripción e interpretación de un mundo musical en sus distintas dimensiones es posible comprender su densidad, prescripción que se encuentra con el abordaje etnográfico elegido.

En esta tesis se entiende la perspectiva etnográfica de investigación en sus dimensiones de método, texto y enfoque, en el sentido que Guber (2011) da a esa tríada. Etnografía como enfoque porque interesa indagar en las categorías que modelan la experiencia de las personas con las que se investigó y los contextos de uso de dichas categorías, lo que implica cierta flexibilidad en la construcción del objeto, que no se define a priori, y en la de los conceptos teóricos con los que se problematiza el análisis, los cuales entran en relación con la teoría sustentada por los sujetos y grupos en estudio acerca de sus propias prácticas. Se trata también de una etnografía como método puesto que se realiza un trabajo de campo etnográfico basado principalmente en la observación participante de las actividades de producción musical en su más amplio sentido. Finalmente, etnografía como texto ya que la escritura pretende singularizar el fenómeno social que se estudia, asumiendo básicamente la forma de una descripción, a sabiendas de que ha sido criticada por su empirismo y/o falta de pretensión generalizadora o teórica. Con Rockwell (2009) y Wolcott (2003) se considera que una buena descripción presupone un trabajo teórico previo, por lo que exponer los resultados de la investigación de esta manera conserva la riqueza de las relaciones particulares que se estudiaron a la vez que permite plantear problemas conceptuales y teóricos.

La producción de datos se basa principalmente en la observación participante y en las entrevistas orientadas por ella, complementándose con el análisis de información documental. Con respecto a la observación participante, se trata de la técnica privilegiada en la mayor parte del trabajo de campo, realizada en distintos eventos de performance musical, en particular recitales y fiestas, como también en reuniones internas del sello, comidas y encuentros con los músicos y otros productores estéticos y algunos viajes a Capital para ir a tocar. Como lugar de observación secundario, dada la trascendencia de Internet en las prácticas musicales actuales y en este campo en particular, realicé visitas regulares a las páginas oficiales de los sellos e interacciones con los actores en los sistemas de blogging o microblogging (especialmente Twitter) y en perfiles, grupos y páginas de redes sociales (especialmente Facebook). Cabe 
enfatizar que el carácter interactivo de la mayoría de estos espacios permite participar de la configuración virtual de las redes de sociabilidad de los actores, y por lo tanto son parte de la etnografía.

Ya que existen ciertos aspectos del mundo de la práctica en estudio que la observación participante no permite captar, como acontecimientos pasados; acontecimientos presentes pero fuera del campo de observación; opiniones, emociones e ideas no pasibles de observación directa o que no tienen lugar en los ámbitos generalmente grupales de la observación participante, la entrevista personal se constituyó en otra técnica relevante para la construcción de datos. Cabe aclarar que al hablar de entrevista se refiere a una forma especial de encuentro, una conversación pautada y personal, para distinguirla del resto de las charlas y conversaciones que se tienen en el campo. Estas entrevistas fueron realizadas a la par de la observación participante y guiadas por ella, ya que se considera que es el propio trabajo en el terreno el que permite definir a quiénes entrevistar y cómo. En este sentido, se realizaron entrevistas personales abiertas y orientadas biográficamente (Alonso 1998) a músicos y artistas miembros del sello en el que se localizó la observación. Esto se comenzó a hacer luego de varios meses de iniciada la etnografía, a fin de tener mayor claridad en las temáticas e interrogantes significativos según el universo cultural de los informantes. En estas entrevistas se realizaron indagaciones dirigidas a dimensiones estructurantes de las prácticas que se encontraron a partir de la observación participante, dimensiones que les suponen un piso de historicidad determinado y su realización en el marco de relaciones de fuerza y conflictos que implican actores y procesos extra locales.

Finalmente, las fuentes documentales que se utilizaron cubren un espectro diverso de materiales. Se incluyen los documentos producidos por el sello mismo: la información escrita extraída de los sitios web oficiales del sello y sus artistas, como de sus perfiles de Facebook y de sus estados de Twitter; fotografías, flyers, videos y otros materiales visuales y audiovisuales producidos por ellos; etc. Por otro lado, es posible nuclear una serie de documentos por su carácter crucial para en el campo. Se trata del material periodístico y aficionado: entrevistas en programas de radio, revistas y blogs, tanto a los músicos en estudio como a otros significativos; reseñas de discos o eventos en la prensa escrita; etc. El criterio que se tomó para seleccionar estos materiales, potencialmente enorme, proviene de la referencia por parte de mis interlocutores en el campo. Estas referencias son regulares, ya que para ellos "la prensa", y en especial "la prensa de rock" goza de un estatus privilegiado en la construcción del problema social 
de la música emergente, los sellos, la escena independiente y demás. Se trata, por un lado, de la importancia de la prensa como multiplicadora del impacto de lo que ellos ya comunican en las redes sociales, como también de su papel en la construcción del valor de la música que se produce. A su vez, no deja de tratarse de un mundo donde el saber sobre bandas, discos, video-clips, recitales, "críticas", aspectos de las biografías de artistas, etc., funciona capitalizando a los actores y por lo tanto es invocado a menudo. En cuanto al análisis, el material -tanto el producido por el sello como el referenciado por sus miembros - recibe un tratamiento etnográfico. Es decir, estos materiales importan en tanto funcionan para volver más densa la comprensión de los significados que los músicos y productores estéticos juegan en su construcción del sello. Por último, se incluye la propia literatura sobre las relaciones entre la música y la sociedad, especialmente las investigaciones empíricas sobre esos temas. Se aboga por un diálogo crítico con esos materiales, que involucre la problematización de la especificidad local de los casos en estudio, atendiendo a su vez a cómo esa variación entra en vinculación con los casos analizados en la literatura.

La posibilidad de construir el objeto sello tal como finalmente fue construido en esta tesis, es decir como uno que no respeta las separaciones académicas convencionales con las que se ha estudiado la práctica musical (obra/artista; estética/economía; producción /recepción) apunta la ganancia que significa la perspectiva etnográfica para esta investigación. Se recupera de este modo un talante fundamental de esta tradición, el de dar cuenta de las conjunciones y divisiones efectivas del mundo de la práctica de los actores, sin presuponerlas de antemano. Como plantea Wolcott (2003), la mirada holística, sensitiva al contexto y a múltiples contextos, es típica de la etnografía como abordaje. Se considera que de esta manera puede estudiarse el sello como una institución sobredeterminada que define la experiencia de una generación con la música, una experiencia indiferenciadora de públicos y músicos que es la vez estética y social, donde la moral y la economía se intersectan para dar lugar a un tipo particular de prácticas de gestión, en el marco del tendido de redes específicas de sociabilidad. 
En los apartados siguientes, se elaboran datos obtenidos en el campo acerca de un circuito de bandas y solistas catalogadas en su mayoría en un sello musical de la ciudad de La Plata identificado, no sin disputas, con el indie, en diversas conexiones con lo independiente y lo emergente. Esta elaboración se nutre de mi trabajo de campo actual con otro sello de la ciudad de La Plata y se orienta desde un interrogante más amplio sobre los proyectos de vida de una generación en la música, en el marco de un cambio de las relaciones entre música, tecnología, juventud y mercado.

Una primera serie de apartados de esta tesis se pregunta acerca de cómo una producción musical y una estética “joven” con un fuerte carácter generacional, correspondientes al mundo del indie, desarrolla bajo un rótulo una especificidad. En este sentido, me pregunto cómo se produce música indie en La Plata, que relación toma con el carácter independiente de la música y qué disposición moral le es característica. ¿Qué es indie y qué es independiente?, ¿qué significa hacer música indie? A propósito de esto, se elaborarán los siguientes puntos: (1) la situación ecológica particular de una ciudad universitaria en la cual los actores producen lo que se llama indie (apartado Un mundo universitario); (2) la distinción entre indies e independientes que resulta pertinente para este campo, resaltando el carácter situacional de esta diferencia y la polisemia de los términos (apartado Indies e independientes); (3) la específica y distintiva disposición moral que estos actores exhiben, la cual moldea formas de producir música y de valorarla (apartado Relajados); (4) la supervivencia como paño de fondo de la categoría careta, cara a la tradición del rock y otras músicas "juveniles” en Argentina, pero también las rupturas que su uso involucra con respecto a otras tradiciones musicales identificadas con lo "joven" (apartado Anti caretas); (5) el valor de la categoría rock en este mundo musical (apartado Rockeros); (6) los lugares en los que se emplazan estas producciones y su geografía simbólica (apartado Lugares de producción, lugares de encuentro).

En una segunda serie de apartados, me pregunto: ¿cómo funciona un sello de esa clase?, ¿cuáles son las condiciones en las que surge y se desarrolla? A su vez, ¿cuáles son las posibilidades profesionalizantes con las que se acompaña a nivel de las trayectorias personales?, ¿cómo estos actores representan sus actividades en relación a la noción de trabajo y a la posibilidad de una carrera? Asimismo, ¿cuáles son las condiciones de mercantilización de estas producciones?, ¿qué relaciones se establecen 
entre dicha mercantilización y las prácticas y discursos que producen la independencia y lo indie? En ese plan, desarrollo los siguientes puntos: 7) las representaciones y proyecciones que se tienen con respecto al trabajo, y específicamente al trabajo en la música (apartado Trabajos, proyectos, carreras). 8) las redes de cooperación productoras de música a partir de una categoría propia del grupo analizado, la del "grupo de amigos", y el modo de gestión musical que de dicha configuración resulta, en relación al estatuto que asume el sello en esta disposición musical particular (apartado El sello); (9), la específica moral económica que estos actores exhiben (apartado La moral económica); (10) una aproximación a la relación con un actor relativamente novedoso en la práctica musical: el Estado, y su vinculación con la gestión de los proyectos musicales (apartado Los aliados: recursos estatales y gestión); (11) las nociones sobre lo independiente en circulación tanto en este mundo musical como en los ámbitos académicos (apartado Independencias).

\section{Un mundo universitario}

Cada vez que llego a la ciudad de La Plata, lugar donde realicé mi formación universitaria, activo un imaginario que me hace notar en cada calle la presencia sensible, y en ciertas zonas, protagónica, de aquellos a los que convencionalmente, es decir con un criterio etario, llamamos jóvenes. A medida que camino por el "cuadrado", es decir el casco urbano del Partido de La Plata, cuidadosamente planeado a fines del siglo XIX por Pedro Benoit, los edificios poblados de estudiantes universitarios, las pensiones, los grupitos en plazas estudiando, charlando o tocando la guitarra, las manifestaciones políticas estudiantiles, los festivales al aire libre, se me hacen postales urbanas características. Los chicos y chicas con los que traté para realizar esta investigación compartían en cierto sentido esa noción de La Plata como ciudad joven y universitaria, poniéndola a jugar en sus relatos sobre la música platense y sus diferencias con la de otras latitudes. Esta idea es introducida también por ciertos abordajes académicos para pensar el arte y las producciones culturales situadas en la ciudad. Vicentini (2010: 26), en un trabajo anclado en la preocupación por la relación entre la música y la juventud, afirma que La Plata es una “ciudad de jóvenes” y que el carácter universitario es un factor que incide notablemente en el rock que allí se produce. 
De esta manera, el imaginario de una ciudad caracterizada por una sociabilidad “joven” y dinámica vinculada a la música y el arte atraviesa muchos de los discursos de los músicos, periodistas y académicos. Es cierto que gran parte de la música que se produce en la ciudad, incluida la que en esta tesis se analiza, no puede escindirse de alguna u otra manera de la presencia de la universidad y de un entorno universitario. Sin embargo, en relación a este problema, más que una ciudad universitaria, hay mundos universitarios, algunos vinculados al rock, como el que se describe en esta tesis. En este sentido, la música y el rock de la ciudad no adquieren un tono específico y homogéneo que permite hablar sin problemas de un "rock platense", y mucho menos de un "rock platense" a la manera de un "rock universitario", como muchas veces se pretende. En realidad, pareciera que los distintos actores yuxtaponen el imaginario de la ciudad el imaginario de la música que la identificaría: imaginan la ciudad de la misma manera que imaginan la música que eligen, totalizando uno o ambos objetos. Entonces, por ejemplo, se afirma una ciudad universitaria para hablar de un rock local de "mucho ensayo" y "vocación artística" (Vicentini 2010: 26), características que, como se verá, no comparten todas las manifestaciones estéticas que reivindican en La Plata la categoría de rock.

Para los músicos y productores estéticos con los que trabajé, la ciudad de La Plata se constituye en un espacio geográfico manejable y amigable, construcción que, como se verá, debe vincularse con la propia articulación moral de su mundo musical. Suelen vivir dentro o cerca del cuadrado: con los padres, con amigos, con sus parejas o solos. Y es en este casco urbano donde básicamente se espacializa la escena (en lugares de grabación, locales de presentación en vivo, centros culturales, radios, aulas universitarias, etc.), por lo que en la producción musical las distancias resultan cortas, los tiempos de encuentro son acotados, los caminos son conocidos, la seguridad con la que se transita es relativamente alta.

Este también es un tránsito en la experiencia de aprender a vivir sin la protección familiar directa, un camino en el que tanto afectiva como económicamente dependen mucho más de los amigos y de los compañeros. La circulación de favores y de préstamos entre ellos, que en estos casos sustituyen con mucha ventaja al dinero, son una situación que se repite típicamente en las redes estudiantiles de La Plata. En el mundo musical que acá estudio, esta situación habilita ciertos relatos acerca de "esas cosas que pasan en La Plata y no pasan en Capital", activándose una idea de comunidad. Así, en nuestras conversaciones me contaban que tales en una época habían vivido 
juntos, que ahora se juntaban a jugar al fútbol entre bandas o que era común que se prestaran entre "todos" los equipos. Todo esto, debe aclararse, no significa que estos músicos no estén fuertemente capitalizados por vía familiar, lo cual resultará clave para entender las prácticas que redundan en el funcionamiento de los sellos.

Con respecto al carácter universitario del mundo de la música indie, resulta significativo que el ciclo anual de sus producciones se corresponda básicamente al ciclo lectivo. Mismo que mi inserción en el campo se produjera a partir de las redes escolares que compartía con algunos músicos de las bandas que aquí aparecen. Facundo ${ }^{19}$, actualmente egresado de la carrera de historia, había sido compañero de una materia optativa, y habíamos desarrollado una relación de pasillo, basada en encuentros casuales. Otro era Mariano, un compañero de sociología, hoy también recibido, con quien compartimos espacios académicos. A su vez, otra compañera me contactó con un amigo personal suyo, organizador de eventos y programador de una radio importante para la escena. Al resto de las personas las conecté en primera instancia dentro de los recitales y luego por Facebook (no deja de ser un dato que teníamos cantidad de amigos en común, tanto personas físicas como bandas, bares de la ciudad, centros culturales y organizaciones políticas universitarias). Todas estas personas me recomendaron a otras, configurando un recorrido particular, mi recorrido, por las redes de un mundo de la práctica de ciertas bandas platenses que han sido identificadas con el indie. Las charlas en los recitales fueron en muchos casos mi primer contacto con estas personas, habilitándome luego conversaciones de chat, entrevistas y eventos compartidos. Mis principales espacios de interacción fueron los recitales: desde fines del año 2009 a fines del 2010 asistí, en promedio, a una "fecha" por semana donde veía por lo general entre dos y cuatro bandas y/o solistas (pero incluso cuando se trata de un solista, suele estar acompañado de una banda).

Este tipo de acceso al campo, mediado desde una adscripción universitaria y una pertenencia generacional común, junto a gustos musicales y consumos culturales que enseguida se revelaron compartidos, conllevó que ellos me entendieran como socialmente cercana. No sufrí la denominada sospecha inicial en que la etnógrafa es percibida como una outsider amenazante del orden (Golde 1986 citado en Moreira 2006). No llegaba yo desde algún lugar social lejano o directamente extranjero: por los

\footnotetext{
${ }^{19}$ Los nombres, tanto de las personas como de algunos sellos, han sido cambiados dado que no cuento con el consentimiento explícito de todos ellos para poder usar sus nombres reales. Sin embargo, introduzco nombres de fantasía porque una completa anonimia no haría justicia al enfoque etnográfico de esta investigación.
} 
motivos expuestos compartía ciertos espacios y redes con estos músicos, como dije la mayoría varones, cuando comencé a interactuar con ellos en un plan etnográfico. Esta indiferenciación bastante importante entre lo que la literatura etnográfica suele llamar la casa y el campo me implicó, no obstante, en un trabajo permanente de extrañamiento de lo que suponía conocido, de verme en la necesidad de exotizar a personas que salían a los mismos lugares que yo y que vivían -literalmente- a cinco cuadras de mi casa ${ }^{20}$.

En este proceso, el trabajo de campo no se limitó a los "artistas" editados por el sello que en este momento estaban en actividad sino a algunas bandas "amigas" con las que se compartían "fechas". Más adelante, en mayo del año 2011, a partir de las redes que había construido en el trabajo con Tigra y de la interacción sostenida y compartida en las redes sociales de Internet, comencé a trabajar etnográficamente con otro sello de la ciudad, Concepto Cero, el cual se relaciona activamente con Tigra y otros sellos similares en el país y la zona. De esta manera, he mantenido el contacto con el mundo indie a su vez que ampliado mis referencias hacia el mundo independiente y sus sellos musicales. Concepto Cero no se identifica con lo indie pero sí con lo independiente, asumiendo características particulares que no serán objeto de esta tesis, no obstante lo cual me ha permitido complejizar la construcción analítica del indie (por contraste) y del sello (por similitud).

Finalmente, una última cuestión con respecto del carácter universitario del universo en estudio. Las personas con las que trabajé, a los que nombro casi siempre como "músicos" (en un género masculino no precisamente neutral ya que como ya dije son en gran parte varones), presentan una procedencia geográfica y económica heterogénea: algunos crecieron en el casco urbano de La Plata, otros en localidades dentro del partido de La Plata como Villa Elvira, Tolosa y Gonnet o City Bell. En cuanto a estas, que en el imaginario urbano la primera esté claramente asociada a las fracciones más bajas de las clases medias y a los sectores populares, la segunda a las clases medias y las terceras a sectores más acomodados, indica que la composición de clase de estos chicos no resulta homogénea. Prácticamente todos, sin embargo, o bien cursaron sus estudios secundarios en alguno de los colegios dependientes de la

\footnotetext{
${ }^{20}$ En cuanto a la reflexión metodológica, lo que atañe a la cuestión de género, la de una mujer en un campo "masculino", será abordada en mi tesis de Doctorado. En este sentido, se trata de un campo donde la mayoría de varones es reforzada por una división del trabajo musical que orienta abrumadoramente a las pocas mujeres hacia actividades desarrolladas tras bambalinas o abajo del escenario (prensa, fotografía, escenografía, etc.).
} 
Universidad Nacional de La Plata (UNLP) o bien hicieron lo propio en alguna carrera universitaria de la misma institución.

Los miembros fundadores y más antiguos del sello, los cuales atravesaban al momento de hacer esta investigación la treintena de años, se conocieron a partir de su paso por distintos colegios pre-universitarios, período en el cual tuvieron sus primeras bandas. Refiero a un grupo de escuelas colonizado por la presencia de padres profesionales y empleados de diferentes esferas de la actividad económica, que valoran la tradición de la escuela pública y la formación ilustrada, a la vez que entienden la educación como estrategia familiar de ascenso social (Ziegler 2007). El hecho de que desde la restauración democrática el ingreso a los colegios dependientes de la Universidad de La Plata no sea por exámenes sino por sorteo matiza en parte el reclutamiento socialmente endogámico, no obstante lo cual, y aún reconociendo las experiencias heterogéneas de estos colegios, se encuentra una pauta cultural asociada a las clases medias.

A ellos se sumaron otros chicos, provenientes en general de ciudades del interior de la provincia de Buenos Aires que, en su mayoría, han pasado también por la experiencia socializadora de las aulas de la UNLP, siendo esa, de hecho, la razón de su llegada a la ciudad, pero no siempre la de su permanencia. Los platenses y los del “interior" siguieron carreras diversas: historia, periodismo, sociología, plástica, diseño, no encontrándose entre las preferencias carreras escolarizadas en la música, lo cual no resulta casual y será retomado más adelante. $\mathrm{Al}$ momento de escribir esta tesis, no puede establecerse una relación homogénea con la universidad: muchos ya están recibidos, algunos, incluso, trabajan en esa institución, mientras otros ya no se vinculan directamente con ella.

\section{Indies e independientes}

Las bandas de Tigra, de Concepto Cero y de los otros sellos con los que he tenido contacto en La Plata forman parte de lo que se llama "escena independiente". Sus producciones no pueden separarse de las nuevas tecnologías que habilitan formas de producción "hogareñas" y/o más fácilmente accesibles, a la vez que permiten una circulación de la producción impensable décadas atrás sin la estructura y el knowhow de una discográfica. Como ya fue presentado, la digitalización también les permite articular estéticas visuales y sonoras en convergencias y conexiones inimaginables 
pocos años atrás, sin ir más lejos, en la década del 90 en la que estos músicos tuvieron su primera socialización musical. Estas características son compartidas por los grupos que analizamos con otros actores de las diversas escenas estéticas independientes de la ciudad; de hecho se presenta una confluencia entre las artes en "fechas" que pueden ser recitales de música y a la vez de poesía, al mismo tiempo proyecciones y ferias de objetos, protagonizadas por personas que pueden definirse en simultáneo a partir de su hacer en la música, el diseño, el dibujo, la escritura, etc.

Podría decirse que en La Plata la mayoría abrumadora de la música producida se inscribe en el sector independiente, en el sentido convencional de que no tiene contratos con grandes sellos discográficos o compañías multinacionales (Yúdice 2008: 11). No obstante, lo que los músicos con lo que trabajé, tanto de Tigra como de Concepto Cero y TICA Red, llaman "escena independiente" (o a veces, simplemente, la escena) no abarca la totalidad de dichos proyectos y se configura a partir de límites difusos y móviles para sus mismos protagonistas. Por ejemplo, estos músicos no consideran que los grupos de nuevo folclore, música popular y distintos estilos fusionados que tocan en numerosas peñas, centros culturales y bares de la ciudad pertenezcan a su escena, si bien en el sentido convencional antes definido podríamos definirlos independientes ${ }^{21}$. Por el contrario, las bandas que forman parte de la escena son identificadas con el rock, con lo rockero. Como se verá luego en detalle, el rock no se identifica con un género o un estilo musical sino, como es muy frecuente, a partir de una serie de actitudes, un universo de prácticas, incluso un modo de vida: el mundo de la cultura rock. Pero aún así esta "escena independiente" no se construye a partir de cualquier rock: no es, por ejemplo, el que Cingolani (2013) en su trabajo sobre la reconfiguración pos Cromañón de los circuitos del vivo en La Plata describe como "rock platense". Las bandas que ella toma como objeto empírico (de barrios periféricos y de la localidad de Berisso, si bien realizan sus presentaciones en el "cuadrado"), son conceptualizadas por mis informantes como "rock chabón" e invisibilizadas como parte del mundo independiente.

Dentro de la "escena independiente", los músicos de Tigra, reconocidos por la prensa y por gran parte del público como "indies", ocupan una posición peculiar basada en una disposición moral "relajada" que los diferencia del resto de la escena, a la vez, incluyendo y excluyendo a otros y a ellos mismos dentro del término con el que se los identifica. A su vez $-\mathrm{y}$ se verá con detenimiento más adelante- como “indies"

\footnotetext{
${ }^{21}$ Si bien refiero a una inmensidad de manifestaciones musicales, mis interlocutores suelen asociarlas a la Facultad de Bellas Artes (sus alumnos, ex alumnos, graduados, docentes, etc.).
} 
prolongan la vigencia de la categoría rock, constituyéndose un caso en el que las categorías de indie y de "rock" se intersectan más que en otros.

Así el sentido de la pertenencia indie resulta situacional y polémico: cuando se habla de indie muchos suponen una imagen que no coincide con la que imaginan otros, si bien suelen creer que hablan de lo mismo. Es una categoría de identificación y autoidentificación bastante generalizada como recurso, lo que hace que viva, como categoría, un interminable proceso de redefinición. En habla inglesa, el término indie ${ }^{22}$ se ha vinculado en un primer momento histórico a las condiciones de producción y circulación de las obras musicales. De acuerdo a la bibliografía especializada, a partir de los años noventa y hasta la actualidad, en momentos variables de ese período según los diferentes países, el indie dejó de ser una abreviatura y de referir a unas específicas, aunque heterogéneas, circunstancias de producción, para pasar a denominar un género (Hesmondhalgh 1999) o bien un tipo particular de música. Así, actualmente, existen bandas que en la mayor parte de sus trayectorias han estado ligadas a sellos discográficos multinacionales, pero que son clasificadas por la prensa especializada y por el marketing de ventas como indie rock (o indie pop e indie folk, entre otras categorías)por su sonido y su estética. De hecho, varios autores documentan la transformación del indie en un estilo o una estética: plantean que hoy este término refiere no sólo a ciertas clases de música "alternativa", editada dentro o fuera de las "majors", sino también a productos culturales como las películas y la publicidad, nuevamente sin consideración de cómo se produzcan, y a otras formas de expresión cultural como los regímenes de la vestimenta (Dale 2009; Hibbet 2005; Newman 2009). En este sentido, es preciso notar que la mayor parte de la bibliografía adjudica un fuerte carácter de clase a estos consumos culturales. Hibbet (2005) en su análisis de bandas de indie internacionales y Newman (2009) poniendo el foco en el cine independiente norteamericano, coinciden en una perspectiva bourdieana para decir que el indie, al mismo tiempo que marca la conciencia de una nueva estética satisface también un deseo

\footnotetext{
22 Durante el período punk/ post-punk temprano en Inglaterra, a partir de 1976, las palabras "independent" e indie, como una abreviatura de la primera, se usaban para designar una concreta separación económica de los principales sellos discográficos, las majors. Esta escena indie temprana, que habría surgido de lo que suele llamarse la "primera ola" del punk, se fundaba en la ética DIY (Do-ItYourself) y en la idea de apoderarse de los medios de producción (Dale, 2009). Pero el linaje histórico del indie es sin duda una cuestión controversial. Hibbet (2005), por ejemplo, lo encuentra mucho antes en algunas bandas de fines de la década del 60, como The Velvet Underground, y en el "college rock" norteamericano de los años ochenta. Oakes (2009) busca las primeras raíces de lo que eventualmente se convirtió en indie en los artistas independientes de los años cincuenta y sesenta, pertenecientes a las generaciones beat y hippie, encontrando hitos posteriores en el movimiento punk, en el riot grrrl, y en la escena de rock independiente de la ciudad universitaria de Berkeley.
} 
de diferenciación social en ciertos grupos, operando como un recurso de distinción. Con una orientación teórica similar, Boerio (2011) entiende el gusto por el indie en la ciudad de Buenos Aires como un modo de afirmación de la clase de pertenencia para jóvenes urbanos de clase media.

En particular, en la zona metropolitana de Buenos Aires, la palabra indie, dada su apropiación y circulación reciente en nuestro país, no refiere a una condición institucional o técnica, ya que para nombrar a quienes se autogestionan o están en sellos chicos o independientes, entre otras alternativas, siempre se ha usado, mayoritariamente, el término independiente. La palabra indie en esta zona geográfica define en principio un estilo ${ }^{23}$, musical pero más que nada estético en un amplio sentido, si bien últimamente su uso se ha expandido para realizar otro tipo de clasificaciones. En cuanto a lo primero, indie define un estilo por el cual se disputa: la configuración particular de las bandas indies en La Plata es un vector de dicha disputa, en su diferencia con lo que se presenta como indie en Capital, pero también, ampliando el mapa, en otras grandes ciudades del país como Córdoba, Rosario o Mar del Plata. Contemporáneamente a la configuración de estas bandas indies en La Plata, el indie se transformó, entre la circulación internacional y el cambio generacional, en un vocablo de uso generalizado entre ciertos sectores de las clases medias, Especialmente entre los músicos, es un término que obliga a posicionarse y que, por lo tanto, es interpretado de distintas maneras, constituyéndose distintas acepciones de él.

En La Plata se suele llamar indies especialmente a los artistas pertenecientes al sello que acá tomamos como objeto, junto a otros que comparten "fechas" y ciertos atributos categoriales con ellos ${ }^{24}$. La justificación suele ser sonora: se los vincula en cuanto a su sonido con el "indie college americano, en el sentido de bandas como R.E.M., Pavement, Yo La Tengo, Pixies, Sonic Youth". Esta asociación es puesta en juego en todos los relatos, especialmente por los periodistas, y es reconocida por la mayoría de los otros actores de la escena independiente local. En este sentido, uno de los músicos fundadores de Concepto Cero me decía: “acá indie capaz se ubica con un

${ }^{23}$ Con estilo refiero tanto a cuestiones musicales como a tipos de atuendo, consumos culturales, elecciones en las formas del ocio y de socialización nocturna, etc. No considero, como en el caso de los subculturalistas, que el estilo ponga en escena un sistema de homologías. Sobre la superación de esta posición y una hipótesis sobre la relación entre interpelaciones y narrativas que da lugar a identidades en el uso de la música: ver Vila 1996.

${ }^{24}$ Brubaker y Cooper (2001) en su discusión de la noción de identidad diferencian entre dos modos de identificación del yo y de los otros: los relacionales, es decir, la identificación por la posición en una red relacional; los categoriales, es decir, la identificación por ser miembro de una clase de personas que comparten algún atributo categorial. 
sonido específico que no es al que particularmente apuntamos". Esta asociación sonora es verosímil, pero una mirada más detenida la revela en su parcialidad: muchas otras bandas de la escena podrían reivindicar por sonoridad este link y sin embargo no lo hacen, lo que no escapa a ninguno de los músicos. Justamente, las bandas indies van a distinguirse y a ser distinguidas por otros atributos, de tipo moral. Son esas disposiciones las que jugarán en los contrastes usuales de estos chicos con el "indie de Capital", con el "rock platense" y con otros actores de la música independiente, contrastes que interpretaré organizados alrededor de la recurrencia de la palabra careta como categoría de acusación.

En el año 2004, donde podemos situar los comienzos del sello y de una de sus bandas consagradas $^{25}$ para la escena independiente metropolitana, denominarse indies y/o usar dicha palabra para promocionar sus fechas tuvo que ver con una necesidad de diferenciarse de otros actores de la escena independiente y de construirse una tradición selectiva de sus escuchas musicales asociadas a dicha palabra, músicas a las que otros pueden negarle, o simplemente desconocerle, la vinculación con el indie. Pero, ya a fines del año 2009, la primera vez que pregunté en el campo qué era el indie, Joaquín, músico y encargado en dicho momento del sello, me contestó un tanto fastidiado: "El indie es una boludez, un problema. Porque se pone de moda esa palabra para etiquetar. Todo es indie y se rompe con lo que originalmente era". Para ese entonces, quienes leemos con asiduidad revistas identificadas con el rock o la "cultura rock" como Rolling Stone o Los Inrockuptibles, estábamos registrando la repetición in crescendo de la palabra indie, siempre con sentidos diferentes. También se notaba esta reproducción incesante en ciertos circuitos cibernéticos, especialmente los blogs y las redes sociales.

Contemporáneamente a ese proceso de explosión de la palabra, en poco más de cinco años los grupos y solistas identificados con el indie en La Plata crecieron en público, en presentaciones, en ganancias, en mejoras en las condiciones de ejecución de la música en vivo y de grabación (por ejemplo en la considerada mayor calidad de las ediciones de discos replicados en fábrica y ya no multicopiados), etc. Estos proyectos musicales pasan de la marginalidad en la escena a una relativa centralidad, que se evidencia en el lugar protagónico que la prensa nacional especializada, en particular los suplementos "jóvenes" de los diarios Clarín y Página/12, le dio a estos artistas,

\footnotetext{
${ }^{25}$ Como ya se sugirió en la introducción y se retomará en la conclusión, la forma y el sentido de esta consagración asume características novedosas y debe entenderse en relación con la escala de estas escenas musicales.
} 
ungiéndolos como la renovación de cierta tradición indie nacional pero también como novedad "rockera". Contemporáneamente a esta centralidad, la palabra indie de ser usada por los chicos de Tigra para nombrar y promocionar sus "fechas". Mientras, para los productores de otros sellos de La Plata, indie se convertía en un adjetivo valorado positiva o negativamente según el caso. En este plan, los usos de la palabra se expandieron para nombrar no sólo a algunos grupos musicales, sino actitudes, formas de trato, sensibilidades, estilos emocionales, modas en cuanto a la apariencia personal, etc.

A partir de este recorrido, puede evidenciarse que la construcción, la disputa, la exclusión de otros y la autoexclusión de la categoría indie es una apuesta permanente los músicos de la escena, un juego que actualizan de forma corriente. En este conflicto, la institución del indie como un estilo implica una disposición moral que combina lo independiente, lo rockero y lo anti careta en un modo de producir que, a partir de las clasificaciones nativas, denomino relajado. Es lo relajado lo ciertamente distintivo de lo indie en La Plata, y lo que le da el tono particular a las clasificaciones de lo rockero, lo careta y lo independiente, los otros tres rasgos compartidos, en apropiaciones diferentes, con los otros actores de la "escena independiente" de la ciudad. Estas clasificaciones instituyen localmente a la categoría indie como una categoría problemática, pero también indican prácticas particulares que configuran con cierta nitidez algunas diferencias de estos actores con otros, dentro de La Plata y la zona metropolitana.

\section{Relajados}

Estos músicos presentan una forma de producir que pienso bajo un adjetivo que ellos usaban mucho y que llegaba a sustantivarse: lo "relajado". A lo largo del trabajo de campo dentro de la escena independiente pude ir observando las diferencias en la forma de organización social de donde la música emerge, en particular entre el mundo más identificado con lo indie y los demás. Justamente, la forma que presento a continuación y llamo relajada resulta muy específica dentro de la escena independiente local, al punto de distinguirlos del resto, que suele burlarse y/o criticarlos por ella.

En primer lugar, ser relajado es entender la práctica del recital como una continuación del ensayo, es decir como un momento que no exige una preparación especial, en oposición a una tradición muy arraigada que ve allí un momento espectacular. Esta continuidad se manifiesta de varias maneras: desde no diferenciar la ropa que visten abajo y arriba del escenario hasta el "ensayo en vivo" que pregonan 
algunas de las bandas. En este sentido, si bien las bandas de Tigra solían ensayar incluso en salas alquiladas para tal fin-la manera en que se planteaban esta práctica era más bien intermitente y no asumía la regularidad, la intensidad ni el compromiso férreo de otras bandas de la escena. Esta ausencia de una disciplina se extendía en general a las otras dimensiones de la producción musical. En segundo lugar, se es relajado porque no se "teatraliza" o se "imposta" en escena la voz, el cuerpo, la actitud, como lo hace la "estrella de rock" a la que se oponen, no sin ambigüedades. Se critica, especialmente, la teatralización de otras bandas de la escena local, que fundan su performance en un vestuario excéntrico, una actitud glamorosa y una relación más distante con el público ${ }^{26}$. En tercer lugar, es relajado no requerir en las ejecuciones musicales un virtuosismo que se considera innecesario. En síntesis, son "relajados" en la dimensión de las formas de trabajo y de presentación en vivo, diferentes de las de otros grupos platenses y de los alrededores, tanto indies como independientes. Esto no significa que estas bandas no puedan compartir eventos, pero de ambas partes se reconocen las diferencias. Así, para los segundos, en algún momento hablar de indie pasó a implicar también hablar de irresponsabilidad y "cuelgue".

En mis charlas con los músicos de Tigra y de bandas "amigas”, muchos de estos motivos confluían y/o terminaban asociándose al tópico de la celebración de la expresividad sobre la técnica. La técnica, tanto en la ejecución de un instrumento como en el uso de tecnologías de grabación, no se rechaza per se sino cuando es más importante que lo que "se tiene para decir". A nivel local, la preferencia por la expresividad se ponía a jugar especialmente contra las bandas que salen del "Conservatorio", marcando su afán de perfección en el dominio de la técnica del instrumento. Como me resumía Daniel, editor de una revista local: "vas al Ayuntamiento [en ese momento, uno de los locales más grandes de La Plata para la escala de la escena independiente, donde se organizaban recitales bajo la modalidad del "pagar para tocar"] a ver cinco virtuosos que se tocan todo y no te mueven un pelo...". Y también se posicionaban contra "las bandas de Bellas Artes", refiriéndose a la facultad dependiente de la UNLP de ese nombre, por su voluntad típicamente vanguardista de deconstrucción de las formas, en el marco de decisiones estéticas que se pretenden conscientes tanto en lo compositivo como en lo interpretativo. De esta

\footnotetext{
${ }^{26}$ Se trata especialmente de una generación de músicos a la que mis interlocutores identificaban como anterior y que, de acuerdo al trabajo de Doeswijk y Ruiz (2007) sobre el "rock platense" de los años 90, apostó sus fichas a la ironía, la teatralidad y el glamour en la escena, la impostación de la voz, una poética poco afecta al realismo y, en algunos casos, la ambigüedad sexual.
} 
manera, se encuentra una diferencia con otras músicas que disputan la categoría de rock en La Plata. Lo que el trabajo de Vicentini (2010) denomina rock platense y caracteriza por su estirpe intelectual, su vocación artística, su carácter universitario y su intensidad en los ensayos, resume justamente una imagen de lo que mis interlocutores despreciaban.

Esta posición, junto a la actitud relajada, puede orientar la comprensión de la preferencia por el "lo fi" (de "low fidelity", técnicamente la grabación de baja fidelidad, pero también entendida como un enfoque estético en la grabación musical e incluso como un género) y por los sonidos "sucios" o "desprolijos". El "lo fi" aparecía al momento de realizar el trabajo de campo como una opción mayoritaria, a pesar de que para otras posiciones dentro de la "escena independiente" local no es más que "sonar mal". Este sonar mal se asocia especialmente a lo que se considera "desprolijo" y "desafinado", aunque debe notarse que estas son categorías de acusación históricas: sin ir más lejos, las grandes figuras del rock argentino pasaron a ser reputadas en un "tocar bien" sólo luego de su consagración. En nuestro campo, el lo fi se asume como un sonido "que no busca los parámetros de estandarización del mercado", es decir "sonidos filtrados, una especie de equivalente a una imagen fotoshopeada", revelando una búsqueda tan estética como moral.

El lo fi permite presentar el ideal de una música que no esté "retocada", o bien, ya que el sentido es flexible, que esté intervenida lo menos posible. Desde la perspectiva de la autenticidad en la música popular (Ochoa 2002), puede interpretarse que estos medios y sus resultados son significados en los términos de un contacto directo con el artista, no mediado por "artificios" de estudio que serían característicos de las sonoridades producidas industrialmente. En este sentido, Alejandro, cantante de una banda del Conurbano que comparte el circuito que acá presento opera un desplazamiento cuando dice: "yo siempre tuve claro que, en cuestión sonora, Viva elástico no era una banda indie, porque aunque suene medio careta lo que voy a decir, a mí me gusta mucho el sonido hi fi. Y no te hablo de grabar en Abbey Road o de masterizar con un capo en Nueva York... Me refiero simplemente a hacer las cosas a partir de otra búsqueda, con una mirada diferente. Me interesa sonar más claro, dentro de lo que se puede." 27 Por el otro lado, el lo fi suele aparecer como el resultado de un modo de hacer música, es decir, es posible hallar en esta forma de tocar y de grabar una

27 En Cuestión de Actitud. Entrevista a Viva Elástico, en http://www.losinrockuptibles.com/entrevivaelastico.html. 
valoración de la prepotencia del hacer, de "tener ideas y sacarlas como sea" como me decía uno de los músicos. Si bien al término del trabajo de campo varias bandas empezaban a incursionar en sonidos "hi fi" (del inglés high fidelity) y/o planteaban las limitaciones del lo fi para el "crecimiento" de sus bandas, tendían a reivindicarlo, pero esa reivindicación debe captarse por su anclaje en este modo singular de hacer música, por su sentido moral asociado a lo auténtico y en cuyo marco debe ubicarse la preferencia estética por lo "desprolijo".

A través de lo relajado, estos actores hacen gala de un minimalismo de la ambición. Refiero a una forma característica en que reniegan de darse importancia: ellos son conscientes de sus límites, desprecian el ansia de figuración, rechazan las ambiciones desmedidas, se burlan de lo "pretencioso". Se manifiestan, en esta tónica, suspicaces con respecto a las retóricas profesionales, asociadas tanto al rock nacional de circulación masiva y a ciertas bandas locales de las que pretenden diferenciarse. Estas perspectivas sencillas para la propia trayectoria musical constituyen una manera de construir la autenticidad indie, que sin embargo no aparece en todas las expresiones musicales y estéticas que reivindican esa categoría. En el contex to internacional, Hibbet (2005) encuentra en el caso de Lou Barlow, a quien considera representativo del indie rock norteamericano, una negativa a tomarse su trabajo musical seriamente. Es necesario notar que Barlow fue miembro de dos bandas importantes para mis entrevistados, Dinosaur Jr. y Sebadoh. La primera, en particular, resultaba muy referenciada en nuestras conversaciones.

En este punto, interesa proponer para lo relajado una hipótesis que capte motivos propios del grupo analizado, a la vez que trascienda la acusación de otros actores de la escena independiente para quienes lo relajado es mera pose o estrategia. Con conciencia de su fragilidad y transitoriedad, interpreto que esta actitud relajada puede entenderse como una manera de habitar espacios y situaciones en las que se percibe que las reglas las ponen otros: "el bolichero", "la prensa", "las discográficas", "el mercado". Ser relajado, despreocuparse de esas cosas que a esos otros les importan, no aceptar por lo tanto sus criterios, resulta una respuesta esperable o coherente ante ese conjunto de restricciones. Esta "relajación" estaría asociada, entonces, a una posición no dominante en el mundo de la música. Es claro que no todos los actores que comparten dichas posiciones actúan relajadamente, pero también es claro que los que acá tratamos pudieron ver y actuar una virtud en dicha posición. En otras palabras, pudieron aprovecharla, no sólo para distinguirse del resto, sino para producir con menos 
preocupaciones y entonces efectivamente producir, sin sufrir de parálisis creativas por no tener el "mejor sonido", por "no saber cantar" o por no responder satisfactoriamente a los cánones dominantes de lo virtuoso.

Esta forma relajada de relacionarse con la música se reconoce subordinada a la gran industria (a veces llamada el "mainstream") en ciertos aspectos pero al mismo tiempo instituye una escena musical y estética relativamente disociada que deja de someterse a las pautas de apreciación de ese mismo sector. Esta escena no tiene como objetivo principal competir con (ni tampoco volverse en algún momento) el llamado mainstream. En este sentido, las dimensiones que en las prácticas de los actores aparecen como limitantes, y que muestran para este análisis su posición subordinada frente a las grandes compañías y multinacionales de la música, son las referidas a la tecnología (el "techo tecnológico" a la hora de producir un disco, por ejemplo) y al dinero y los recursos necesarios tanto para obtener esas tecnologías como para realizar diversos productos y eventos. No obstante, esta situación asimétrica y desigual para los músicos emergentes no invalida el punto de que esta escena se constituye y se mantiene como tal, a partir de una forma de producción particular, una escala y un radio de acción propios, una dinámica específica de creación de públicos y unos criterios de legitimidad y autenticidad diferentes.

\section{Anti caretas}

Ser relajado es también no ser "careta". En el caso aquí estudiado, la noción de lo careta y las alterizaciones a las que ella sirve involucran distancias estéticas, pero más que nada morales. Puede interpretarse que si bien el término careta mantiene en tanto categoría trans-generacional su valor histórico en el sello que estoy analizando como lo falso y lo adaptado al orden, lo que no transgrede la legalidad o la costumbre, sus usos y significaciones no dejan de ser diferentes en comparación a grupos de jóvenes de ayer y de hoy. En el rock nacional anterior a la guerra de Malvinas lo careta aparece en las letras como metáfora de la hipocresía del establishment social y político (Alabarces 1993), mientras la acusación de "chetos" aparece hacia dentro del propio movimiento del rock e inicia la sospecha sobre los "falsos rockeros", en este caso, los miembros de las clases medias altas que se acercan al rock en un actitud considerada advenediza (Vila 1985: 142). Luego, el código social operante hasta entrados los años noventa fue el de la oposición loco / careta, donde el loco era el transgresor, el que se vestía 
diferente, el que se identificaba con la cultura rock (Wortman 1996: 121) o el que "curte la personal" sin importarle lo que opinen los demás, mientras el careta trabaja o estudia y obedece (Auyero 1992: 136).

Más recientemente, Alabarces et al (2008) conjeturan para el campo de la música, un desplazamiento de la evaluación estética desde estas preferencias éticas, constituyéndose un marco normativo que enviará determinada músicas y grupos al terreno de "lo comercial" - de "lo cheto" o "lo careta"-, juzgándolas ética antes que estéticamente. Semán y Vila (2008) complejizan esta idea, al plantear que si bien en el imaginario común al rock y a la cumbia actuales, caretas son los que no transgreden ninguna regla, los énfasis que cada grupo realiza son distintos. En este sentido, Garriga (2008) presenta el caso de los "roqueros" de las clases populares quienes articulan lo comprometido, lo contestatario, lo solidario y lo descontrolado para organizar un sistema de diferencias prácticas con los caretas, definiendo nuevamente categorías nativas muy específicas que se ligan directamente a la moralidad e indirectamente a la música.

En nuestro campo, los caretas resultan quienes son "demasiado prolijitos" cuanto tocan, quienes privilegian "tocar con zapatillas nuevas" o "llevar un montón de equipamiento innecesario", quienes están más interesados en "ver quién toca primero, quién segundo" y por lo tanto "están pendientes de boludeces", es decir, de cuestiones que evidencian una ambición inaceptable. La categoría careta también funcionaba oponiendo a las "bandas de la Plata" (o "del Conurbano") con las "bandas de Capital" a partir de una sensibilidad seducida por lo "popular" que sería típica de las primeras, manifestada en una vinculación declarada con las vertientes más plebeyas del rock y, aún más, con un imaginario plebeyista en el que el fútbol es la clave y Diego Armando Maradona con apariciones en flyers, citas y videos quizá el ícono predilecto. Como dice Garriga (2008) para su caso, socialmente lejano al que acá describo, "el límite que los distingue con los "chetos" es presentado, visibilizado $\mathrm{y}$, deberíamos afirmar, sobreactuado", ya que diferenciarse de los caretas siempre es correcto en términos políticos, porque estos están asociados a una difusa clase dominante y a la falta de riesgo, en referencia tanto a consumos musicales como de drogas. Esto moviliza para el régimen de categorías del indie platense un acervo histórico de categorizaciones en sus versiones más actualizadas. 
Estas retóricas de lo plebeyo fueron evidenciadas y traducidas por la prensa capitalina con la expresión "indie cabeza" 28 en oposición a una tradición de indie a secas que habría sido característica de la Capital, indie presentado por esa misma prensa como "sofisticado", "delicado" y "abúlico". Si bien en un primer momento estas bandas no vieron con buenos ojos dicha expresión - de hecho yo me enteré de su existencia porque uno de los chicos vino a contarme, indignado, de la actitud "gorila" de llamarlos "cabezas"- la nota tenía buenas intenciones y los presentaba como una fresca renovación del indie local. Luego este sintagma (y otros, como "indie chabón", “indie barrial" y, más recientemente, “indie pulenta" ${ }^{, 29}$ ) se viralizaron en la prensa especializada, los blogs, las redes sociales y las interacciones cara a cara. Es de notar que estas retóricas aparecen también en otras producciones musicales que comparten audiencia con nuestro objeto, por ejemplo la cumbia electrónica del festival Sonidero Tropicalia estudiada por Vecino (2010). Según su trabajo, estos actores juegan su diferencia con el circuito Zizek (Irisarri 2010 2011) alegando una "mayor autenticidad" y cercanía con las tradiciones populares de la cumbia. Es probable entonces que el relativo éxito de estos desplazamientos, pero también su polémica puedan leerse como parte de un clima de época más amplio.

Finalmente, nos encontramos con una retórica que opone el "arte" al "mercado" o al "comercio". El juego nativo a favor del arte entra en contradicción -desde el punto de vista de los actores- con algunas prácticas concretas como la contratación de un manager, figura históricamente asociada a la mercantilización de la producción musical y a la profesionalización del artista. En este sentido, en nuestras conversaciones ellos relativizaban la presencia del manager en términos de "bah, pero lo hace por amor al manager, no pide plata ni nada", mientras que uno que realizaba dichas funciones me decía "más que un manager, soy un agitador, manager es una palabra horrible".

Sin embargo, estos músicos no dejan de ironizar de manera corriente sobre la acusación misma de "venderse", la cual refiere al conflicto constitutivo del rock en nuestro país en su época ascendente y consagratoria posterior al conflicto de Malvinas (como muestran, Vila 1985; Alabarces 1993), que sigue sosteniendo (o intentando sostener) su valor sobre el eje comercial - no comercial. En nuestro campo, esta

\footnotetext{
${ }^{28}$ Strassburguer, Juan Manuel (2008), "Llega el indie cabeza", Suplemento NO, Página/12, 5 de Junio de 2008, http://www.pagina12.com.ar/diario/suplementos/no/12-3430-2008-06-10.html.

${ }_{29}$ Véase un buen artículo recopilatorio de esta discusión en Vecino, Diego (2011), "Cabezones", Suplemento Ni a Palos, Miradas al Sur, 24 de Junio de 2011, http://www.niapalos.org/?p=4113.
} 
oposición inicial y clásica que les viene de la historia del rock en la que se han socializado, antagonismo que algunas grandes bandas supieron mantener en su consagración, pierde su carácter agonístico excluyente. En otras palabras, la oposición careta-loco deja de ser correspondiente con la oposición mercado-arte. Ya el inicio de las trayectorias de estos músicos apunta a otra consumación: plantean esa tensión, sí, pero se oponen más a lo careta y a lo no relajado y "ambicioso" que a "lo comercial", dado que lo "comercial" ya no se identifica necesariamente con lo careta. Como vemos, las representaciones de lo careta comienzan a admitir compatibilidades que antes no admitían, y una condición que parece estar asociada a esta situación es la mayor legitimidad que adquieren en este campo categorías vinculadas a la noción de mercado.

\section{Rockeros}

A partir de una instrumentación clásica de bandas de rock (guitarra, bajo, batería, teclados), las canciones de estos grupos suelen presentar una duración convencional o estándar que promedia los tres minutos. En ellas se apuesta a una poética de la sugerencia, a un decir fragmentario pero contundente que privilegia lo conceptual sobre lo narrativo. Para ello muchas veces nombran, a modo de códigos generacionales, mecanismos de video juegos, películas, comics y otros productos culturales instituidos como íconos de la cultura pop de los ochenta y noventa, años en los que quienes cantan fueron niños y adolescentes. Siempre como oyente, puedo decir que existe una afección bastante marcada por la distorsión, los "ruidos" y las capas sonoras. Acaso ya sea obvio, al contrario de otras expresiones de la escena independiente de La Plata, la referencia estilística a músicas locales, como el tango, el folclore, las sonoridades rioplatenses y las músicas latinoamericanas es prácticamente nula. Esta característica también los distancia de algunas expresiones del indie tal como se lo considera en Capital Federal. El trabajo de campo de Peña Boerio (2011) con recitales de bandas como Onda Vaga, que reivindica un sonido centroamericano e incluye entre sus instrumentos habituales el cuatro venezolano y el cajón flamenco, como también de cantautores del estilo de Pablo Dacal, quien suele tocar con una pequeña orquesta e interpretar canciones de Discépolo o el cantante Rodrigo, nos permite marcar esta especificidad del caso platense. Esta particularidad sonora acompaña la posición moral antes presentada, la que intersecta al indie con el rock. En La Plata el indie es rock, pero no sólo como "actitud", sino también por su familiaridad 
con las sonoridades y las formaciones de banda más arraigadas en la imaginación del rock como tradición.

Estas producciones musicales se caracterizan por apostar, por lo general de modo deliberado, a la erosión de los géneros musicales, verificando la relativización y porosidad planteada para estos hoy en día, especialmente entre los jóvenes, en su sentido etario (Ochoa 2003; Semán y Vila 2008; Semán 2011; Gallo y Semán 2013). Para mis interlocutores, las bandas "de género" son bandas sin personalidad, sin un "estilo propio". Como escribía romántica en Twitter una de las bandas, poniendo en palabras su pretendida lógica de lo inclasificable: "Lo bueno del indie es que es amigo de todos los géneros, no todos los géneros son amigos del indie, les molesta su libertad" 30 . Sin embargo, ciertos géneros son más amigos que otros: en su práctica musical, estas bandas se filian más fuertemente a géneros y subgéneros musicales internacionalizados con diferentes relaciones de cercanía y superposición como el noise, el space rock, el kraut, el dream pop, el post rock, el garage rock, entre otros.

En cuanto a las "influencias" que ellos reconocen como legítimas están sujetas a los efectos de historización de las propias escuchas musicales y a la legitimidad cambiante de los artistas admirados. En sus declaraciones suelen aparecer sólo algunas de sus escuchas (que incluyen también artistas nacionales, especialmente algunos que produjeron en la década del noventa y que hoy se reconocen como pioneros del indie), cuya rareza no deja de prestigiarlos, en el marco de redes de jóvenes donde se valoriza un conocimiento culto, hasta diría esotérico, de la historia del rock. A ello hay que agregarle una apropiación altamente selectiva de la cultura pop, especialmente norteamericana y una mirada atenta en los sellos independientes extranjeros. Todo ello no se contradice con un énfasis localista: la fuerte creencia en un sonido o "un estilo La Plata”, que parte de la constatación de una rica tradición musical y rockera en la ciudad, con bandas históricas de culto, que para estos actores son más bien Embajada Boliviana y Peligrosos Gorriones antes que Los Redondos o Virus. Si bien hay quienes tienen un público bastante extendido, estas bandas y solistas son, al decir de uno de los habitués de los recitales, "bandas de bandas", con lo que se marca su carácter minoritario y que gusta de pensarse entendido, como, a la vez y principalmente, una escala de producción, circulación y consumo donde, al menos en La Plata, los amigos son centrales.

\footnotetext{
${ }^{30}$ En https://twitter.com/ElMato/status/177923879543635968
} 
Peña Boerio (2011) plantea para los músicos indies de la ciudad de Buenos Aires y su área metropolitana que, si bien por sus trayectorias e influencias musicales pertenecen al género del rock, no se disputan la pertenencia a él, por considerar que representa el pasado. Nuevamente, el contraste con su trabajo nos permite pensar la especificidad del caso platense. Aquí, a partir de una postura presentada como una "actitud", los músicos se posicionan contra la tradición hegemónica del rock argentino luego de 1983, la del mercado de unas pocas grandes bandas, los grandes estadios, la espectacularización y la hiper-profesionalización. En otras palabras, se colocan en contra de mundos del rock que se consideran muertos, estancados o anacrónicos. Sin embargo, a diferencia de lo presentado por Peña Boerio, esta diferencia no implica una distancia con los conceptos del rock. El rock aparece como traidor de sí mismo, pero a la vez como algo a reivindicar. Es como si estos actores dijeran "el rock ha muerto pero nosotros somos el rock": es justamente en lo relajado y en lo anti careta que sigue siendo posible hallar un valor de transgresión alrededor de una categoría de rock redefinida. En esta redefinición, se encuentra la clásica operación de identificar el rock con una forma de vida alejada de (e incluso enfrentada con) los parámetros convencionales de la "buena sociedad", como también lo hizo el llamado rock nacional (Vila 1985). De esta forma no se desmarcan de la actitud atribuida al rock y en este sentido lo prolongan. Por el contrario, sí se distancian del carácter resistente del rock en relación a su enfrentamiento clásico con "lo comercial", en contraste con el rock nacional pasado y actual, que por ello es mirado con escepticismo e incluso con ironía. Por el otro lado, y especialmente, esta resignificación es también una distinción con la cultura rock masiva: una cultura que pasó de producir jóvenes a producir juvenilidad, y una juvenilidad con un nivel de consumo lo suficientemente alto como para alejar a estudiantes universitarios que no tienen liquidez.

\section{Lugares de producción, lugares de encuentro}

Acaso una obviedad, quizás tan obvia que muchos trabajos académicos parecen olvidarla, toda música necesita un lugar para producirse y presentarse. ¿Cuáles son los espacios dónde se emplazan las producciones musicales de estas bandas? En otras palabras, ¿dónde ensayan, construyen su repertorio, y graban? ¿Dónde, por otro lado, dan a conocer a los públicos su trabajo? Faulkner y Becker (2011: 149) en su trabajo localizado en Estados Unidos sobre la construcción del repertorio del jazz (y la 
dinámica de sus músicos en el escenario) construyen un concepto de lugar como un espacio físico (ya sea una construcción o un espacio delimitado al aire libre) que se encuentra socialmente definido por el uso que se espera darle, por expectativas compartidas acerca de qué gente llegará ahí y también por los acuerdos financieros subyacentes. En este sentido, un lugar es una combinación de espacio físico, acuerdo social y pacto financiero (Faulkner y Becker 2011: 154). En esta orientación, es posible preguntarse: ¿Por qué estos músicos emergentes eligen ciertos lugares y no otros? ¿Qué criterios privilegian a la hora de elegir un lugar? ¿Qué relaciones mantienen o esperan mantener con los dueños de los lugares? Como se verá a continuación, estas elecciones deben entenderse desde una disposición moral específica, articulada por la distinción ya expuesta de lo careta- relajado.

En primer lugar, debo decir que no he tenido acceso en esta investigación a los espacios de ensayo y grabación, ámbitos que incluso desde la musicología han sido muy poco estudiados: como plantean Madoery (2000) y Novoa (2010), precisan de un estudio de campo complejo y sistemático que hasta el momento no se ha emprendido, al menos en nuestro país. Puedo, no obstante, establecer algunas cuestiones generales, empezando con que la mayoría de las bandas se inician ensayando en sus casas o en espacios prestados por familiares o amigos. Posteriormente, con el crecimiento de la banda, es probable que comiencen a alquilar una sala. Sin embargo, no se describen trayectorias lineales donde las condiciones de ensayo mejoran inevitablemente.

En cuanto a la grabación, en los comienzos primaba el uso de computadoras hogareñas, ya que como ellos mismos afirman, dando cuenta del impacto del avance tecnológico, hoy "con un poco de plata cualquiera puede tener en la casa un set de grabación de mucha calidad". Con el correr de los discos se comenzó a recurrir a instalaciones "específicas de estudio", más o menos "caseras", es decir, las que cuentan con la llamada "pecera" que divide la cabina, o sea el lugar donde se toca, del lugar donde están los controles y las computadoras. Hay que indicar, igualmente, la heterogeneidad de las condiciones de grabación entre las bandas. Mientras para la mayoría sigue siendo corriente que la grabación combine varias locaciones, varias de ellas hogareñas, con el objetivo de ajustarse a un presupuesto acotado, una de las bandas 
“consagradas", de acuerdo a sus compañeros y la prensa especializada, grabó su último disco en los renombrados estudios Ion $^{31}$.

Si bien hay varios estudios en La Plata más o menos sofisticados que cobran generalmente por hora, las bandas con las que traté prefieren los montados por amigos. Se trata de jóvenes emprendedores, generalmente músicos, que intentan de este modo hacer algo que les gusta asegurándose una entrada económica. Mariano me explicaba: "Lo que suele suceder es que los que empiezan a hacer trabajos de grabación arrancan en su casa, en una pieza y luego van "evolucionando", montando un lugar específicamente preparado". Estos estudios no son, sin embargo, lo que se dice "profesionales", categoría generalmente reservada a ciertos estudios de Capital como el mencionado Ion o Panda, donde suelen grabar grandes figuras de todos los géneros musicales. Sin embargo, la existencia de dichos estudios habla también de una división social del trabajo en este mundo musical, la cual abre diversas posibilidades profesionalizantes para sus participantes. De hecho, algunos de ellos apostaron fuertemente a esta veta y hoy cuentan con estudios muy bien equipados, elegantes y referenciados por el resto. El estudio que montaron unos músicos del sello en Capital Federal donde se grabaron varios de los últimos discos editados es, según opiniones expertas de otros dueños de estudios platenses, "más pro" que los citados como mejores estudios de La Plata.

En cuanto a los lugares para tocar, como recuerda uno de los músicos, eran en los comienzos "centros de estudiantes, casas de vecinos...cualquier lugar". Las posibilidades actuales a la hora de conseguir locaciones son innegablemente mejores, gracias a la reunión estratégica en el sello y la notoriedad alcanza por él (que arrastra a las bandas "amigas" con las que se comparten fechas), a lo que se agrega el peso de la trayectoria. Decía Joaquín “ahora, con diez años tocando, o un poco más, (...) tocamos más o menos donde queremos (...) tenemos una infraestructura armada. Un lugar donde tocar en condiciones dignas."

Sin embargo, independientemente de su posición, todas las personas con las que traté a lo largo del trabajo de campo solían quejarse de la falta de lugares. La importancia de contar con lugares donde se respeten las "reglas" de su trabajo colaborativo se conecta con la proyección de contar en algún momento con un lugar

\footnotetext{
${ }^{31}$ Localizados en la ciudad de Buenos Aires, estos estudios son ampliamente referenciados dentro de la escena por su carácter profesional y por una historia por la que han pasado grandes figuras del rock nacional.
} 
propio. En cierta ocasión, me dirigía en una combi con algunos músicos de la escena a un evento en una ex fábrica textil heredada por un músico radicado en la ciudad de Buenos Aires. Ubicada en San Telmo, había recuperada como taller, espacio de encuentro y local de fiestas por un colectivo de artistas musicales y visuales. Mis acompañantes en el viaje se preguntaban, entre risas pero a la vez proyectando problemas que consideran serios, cómo podía ser que no hubiera un músico, de entre todos los músicos de La Plata, que hubiera heredado algo. De inmediato, casi todos los músicos presentes compartieron su deseo de tener un centro cultural o un bar donde poder tocar ellos mismos y programar las bandas que quisieran.

En cuanto a los lugares realmente existentes, lo que orienta las preferencias en primer lugar es la convicción de no pagar para tocar. Absolutamente todas las personas con las que traté en mi trabajo de campo se declararon en contra de esa práctica y de los lugares que la habilitan, a los que califican con la dureza de expresiones como "usureros" y "saqueadores de bandas". Lo que se juega aquí no es meramente una cuestión económica, teniendo en cuenta que un buen arreglo con el propietario del local puede dar ganancias que permitan seguir produciendo, sino también una cuestión de honor manifestada en el orgullo de decir que no se paga para tocar. Este sentido del honor puede ampliarse hacia dimensiones ya abordadas: una vez le pregunté a uno de ellos por qué no tocaban en el Ayuntamiento, lugar referenciado ampliamente por sus arreglos financieros poco favorables, y entonces me dijo: "hay músicos que piensan que Ayuntamiento les da un nivel profesional, en cuanto a luces, sonido, todo eso...es una farsa, pero se justifican de esa forma la guita que están bajando ahí” (...). Según el entrevistado, estos otros músicos pagan para tocar justificándose en las mejores condiciones de ejecución que obtendrían, de esta forma se convencen de que no son “unos boludos que están pagando 1200 pesos, cuando vas a tocar en Pura Vida, vas a llevar más gente, no suena tan bien, sí, convengamos, pero te va a ir más gente y con más onda." Para ellos, por el contrario, el motivo del pagar para tocar fundado en un "nivel profesional" (o, para retomar sentidos ya expuestos, en un "sonar bien") pierde sentido desde el momento en orientan sus prácticas contra él (en lo que respecta a lo profesional entendido en relación con la calidad sonora).

En segundo lugar, puede pensarse que algunos locales son evitados por su emplazamiento en circuitos nocturnos muy centrales: refiero especialmente al emplazado en la diagonal 74. Sus espacios ostentan una infraestructura y ambientación que aspira a la sofisticación, el alcohol se cotiza más caro y se exige cierto arreglo para 
ingresar. Estos artistas prefieren lugares situados en zonas más tranquilas, siempre dentro del "cuadrado" por cuestiones de accesibilidad. A su vez, si bien pueden llegar a tocar allí, no son las mejores "fechas" las que se realizan en sitios institucionales, como los centros culturales dependientes del municipio, o en sitios que para estos músicos tienen una connotación familiar, incluyendo los espacios que ofrecen actividades para otras franjas etarias, especialmente los niños.

A los fines de entender el tipo de sensibilidad que orienta la elección de los lugares para tocar en el mundo indie, es iluminador describir un circuito nocturno que divide aguas en la escena independiente, y que coloca a los chicos de Tigra claramente de un lado. En el sector comercial del barrio Meridiano V, que apuesta al pintoresquismo en la conservación de casas bajas, calles empedradas y antiguas farolas, entre tiendas de diseño, talleres de artistas y restaurantes, se encuentran algunos bares y centros culturales habilitados para espectáculos de música en vivo. Este circuito es, quizás, muy cercano al que aquí presentamos, dado el carácter de unas propuestas que involucran un público entendido y universitario, e incluso en ciertos casos solapado con el de este estudio. Uno de sus bares, llamado Ciudad Vieja, tiene particular gravitación, ya que suelen tocar allí bandas de la "generación anterior" del llamado "rock platense", frente a las cuales se operan fuertes distinciones. Este bar es también elegido por bandas de jazz y música contemporánea, cuyo virtuosismo y "academicismo" es rechazado. Como decía Damián "En Ciudad Vieja [tal banda] no puede tocar, convoca pibes que se le suben a las mesas al gordo [el propietario de Ciudad Vieja] y se vuelve loco." Además, refiriendo especialmente a la permisividad en el consumo de drogas, la percepción era que este lugar no se tolera "cualquier cosa". Hay, como se dice, "otra actitud". Es decir, en Ciudad Vieja la disposición misma de las instalaciones atenta contra los tipos de presentaciones que se pretenden y los comportamientos que se esperan, a la vez que se asocia a un tipo de música que es rechazada.

En este marco, el espacio favorito de las bandas con las que traté es el bar Pura Vida, ubicado en la diagonal 78 entre 8 y 61, a pocos metros de la Facultad de Bellas Artes. Su fachada es la de una casa antigua, y se emplaza frente a una plazoleta graffiteada donde bancos de madera tipo deck soportan diariamente a una gran cantidad de jóvenes que comparten comidas, toman cerveza, organizan festivales contra alguna política gubernamental y/o universitaria, reparten folletos, venden discos pirateados, fuman porro o pasan el tiempo, a casi cualquier hora. El bar abre generalmente de jueves a domingo, y tiene una programación exclusiva de bandas "independientes" de 
estilos diversos que se cuidan de no combinar en una misma velada. Es un lugar oscuro con una decoración sobria, para muchos un "antro". Como me introducía Joaquín sintetizando el sentir general: "Yo toco en Pura Vida solamente. Es un lugar donde te dejan tocar, no te cobran plata, te dejan encima la plata de la puerta y te dan cerveza además. El dueño es un genio, una vez le planteé que quizá no le convenía pero me dijo que era lo correcto." Otro agregaba una reflexión en el mismo tono: "Pura Vida es el mejor lugar del mundo porque vas a probar sonido a las 12 y media de la noche, te regalan cerveza, no tenés que contratar el sonido, nadie te hincha las pelotas y encima te dan la plata de la puerta." En otras palabras, el bar no sólo ofrece posibilidades que otros locales no dan (sonido propio, horarios flexibles, etc.), sino que les permite conseguir una ganancia, y a la vez se presta al modo de trabajo relajado que describí. Me decía Damián, “en Pura vida podés hacer lo que querés. Nadie te va a decir: 'no, eso no me gusta", , refiriendo particularmente a la permisividad en el consumo de drogas y al hecho de que quienes lo manejan son "del palo".

A este mapa de locaciones debe agregarse la proliferación en la ciudad de La Plata de espacios culturales. Esta emergencia es contemporánea a la de sellos musicales, con quienes se guardan afinidades en las formas de trabajo, como se verá más adelante. Sitios como Casa C'est la vie, Galería Mal de Muchos, Librería y Galería Siberia, Club Galería Cösmiko, ponen en escena a una nueva camada o generación de productores culturales en el dibujo, la pintura, el graffiti, el grabado, la música y la producción audiovisual (López 2013). De acuerdo a mis observaciones, el espíritu intimista de estos espacios, el trato amigable y cálido, su permisividad en el consumo de drogas y su cuidada programación de bandas y DJs, los ubican como un lugar de fuerte identificación estilística y moral con las bandas del mundo indie. Dadas sus pequeñas dimensiones, suelen ser elegidos para realizar conciertos solistas por músicos cuyas bandas no pueden tocar ya en espacios reducidos. También para organizar veladas literarias por los que además de música escriben poesía. A su vez, son frecuentados como lugares de diversión diurna y nocturna por muchos de ellos. Especialmente con los dueños y amigos de Mal de Muchos, una casa que funciona como galería de arte y local de diseño, los músicos de Tigra tenían una estrecha relación, constituyéndose en un lugar para presentar su música, exhibir otras producciones estéticas propias, vender sus objetos de diseño y discos, encontrarse con amigos, comprar ropa, etc.

No obstante, muchas bandas crecieron demasiado como para tocar en Pura Vida, aunque quisieran. Asimismo, una banda indie puede negociar una presentación en 
Ciudad Vieja, si bien no sea el sitio que elegiría si le tocara organizar la fecha por su propia cuenta. Pedro, al contarme que el cantante de otra banda los había invitado a tocar a Ciudad Vieja me decía: “yo creo que esas cosas en el fondo del corazoncito indie de todos nosotros las seguimos criticando un poco, porque si te cruzás con Joaquín y te dice "eeeh careta, te vas a tocar a Ciudad Vieja" y a mí también me parece un poco careta pero todos ya nos flexibilizamos al respecto de eso...". En este panorama, no fue la intención en este apartado trazar planos rígidos de los espacios de celebración pública de estas bandas, sino marcar un mapa de posibilidades y preferencias, tratando de vincular estas elecciones con las características morales del mundo musical en estudio.

\section{Trabajos, proyectos, carreras}

Por un lado, era común escuchar que las bandas "no tocaban por dinero", sino "por amor", "por placer" o "porque se nos da la gana". No obstante, también se reconocía el esfuerzo, la dedicación de tiempo e incluso las inversiones de dinero que la música demandaba. En una entrevista Lucas, músico, empleado estatal y licenciado en sociología, me decía: "estamos todo el tiempo laburando. Laburando de mil maneras distintas, qué sé yo, por Internet, yendo a Pura Vida a pedir fecha, a la radio, haciendo entrevistas, estamos todos todo el día laburando para que la cosa se sostenga". Este juego de citas permite pensar dentro de la actividad musical al menos dos tensiones. Primera, se toca por placer pero ese placer va forzosamente acompañado de varias actividades que no siempre pueden entenderse de ese modo, y de otras directamente indeseables, por ejemplo lidiar con SADAIC (y con las “cuestiones burocráticas”), con algunos empresarios de la noche, con los encargados de las disquerías y las distribuidoras, entre otros. Segunda, se sabe que de algún modo se trabaja en la música, pero no todos la consideran un trabajo, al menos no en esta instancia de sus trayectorias.

Para algunos, el trabajo es el trabajo fuera de la música, remunerado pero no necesariamente bajo un régimen de salario regular. Justamente, para ellos estas actividades artísticas son posibles por el trabajo así considerado en otros mundos de la práctica. Ya sea en relación de dependencia con organismos públicos, como la Municipalidad, los ministerios provinciales, la Universidad o con empresas privadas. En estos casos, la representación de la trayectoria musical se desvincula relativamente de la obtención de medios de vida. Para otros, el trabajo aparece vinculado de alguna manera a la música y el arte: como se vio, algunos tienen salas de ensayo y/ o estudios de 
grabación, que prestan o alquilan, de acuerdo a quién se trate o para qué se lo requiera. Hay también quienes realizan trabajos freelance de diseño gráfico, dibujo, etc., y quienes cuentan con sus propios emprendimientos a ello dedicados, vendiendo indumentaria y objetos de diseño en algunos locales de La Plata y Capital.

En todos los casos, la mayor o menor solvencia económica asegurada por estos trabajos es combinada a veces con una estadía prolongada en la casa familiar, el sostén de sus estudios y/o el alquiler pago por parte de los padres, entre otras situaciones. Esto permite la aceptación, al menos en este momento de la trayectoria vital, de que la actividad en la música no proveerá de la totalidad de los medios de vida (incluso a veces se enlaza efectivamente a la inversión financiera para costear sus producciones estéticas), situación que no sucede en otros mundos musicales donde los artistas supeditan con bastante intensidad sus prácticas a las posibilidades de vivir económicamente de ellas, caso paradigmático, para la misma zona geográfica, el de la cumbia (Tranchini et al 2009) y, para el contexto cordobés, el de los cuartetos (Blázquez 2009).

En este contexto, aunque los capitales invertidos nunca sean muy grandes, se vuelven suficientes en los términos de los actores, que no sólo capitalizan dinero sino situaciones familiares, trayectorias escolares y relaciones afectivas. Por un lado, esta situación funciona a la manera de un crédito semilla, por el otro, no juegan a ser empresarios ni de hecho, como explicaré más adelante, su sello llega a ser una empresa. Pero lo que de hecho se produce es que se desarrollan de una forma sustentable en el mundo de la música.

Ellos dicen que no es que no pretendan "ganar algo de plata", pero creen que en Argentina, y haciendo la música que hacen, no pueden aspirar a "vivir de la música", en el sentido de vivir de tocar y de vender discos. Existe una marca del orden de lo relajado que hace que la expectativa, más bien, sea volver esta actividad autosustentable: una situación, como resumía uno de ellos, en la que "si no ganás, al menos no perdés" y "si da ganancias, da ganancias". En este sentido, se tiende a la coexistencia o complementariedad con otras actividades, donde el sentido de la oportunidad también juega un papel importante; como me decía Facundo "en un momento regás más una planta que otra". Debe notarse que la complementariedad es una posibilidad novedosa, “integra el arte en la trayectoria vital más allá de la zona límite en que otrora parecía imponerse la opción entre 'la guitarrita' y las obligaciones” (Gallo et al 2011: 27). Esta complementariedad no impide que algunos de ellos busquen perfilar una carrera en la 
música: producir mejores discos, realizar presentaciones "más importantes", tocar con artistas admirados, visitar otros países, gustar a más oyentes, etc. Por último, algunos casos "exitosos" o incluso, en los términos de la escena, "consagrados", alertan sobre la posibilidad de que la actividad musical termine funcionando como medio principal de vida.

\section{El sello}

Como ya fue introducido, la constitución de colectivos musicales bajo la forma del sello se ha vuelto una tendencia relevante para la música independiente y/o emergente producida en los centros urbanos de la Argentina y, en particular, en la zona metropolitana de Buenos Aires. A un nivel macro, esta situación puede inscribirse en una tendencia global en el incremento del número de compañías indies y de sus ventas, una consecuencia, en buena medida, de la disminución de los costos en las tecnologías de grabación, gracias a la invención de la digitalización a fines de los 70 (Ochoa 2003). En el contexto local, el trabajo de Palmeiro (2005) documenta para una época más o contemporánea a esta investigación más de setenta sellos activos en la ciudad de Buenos Aires, a la que considera el nicho discográfico argentino por excelencia. La mayoría de ellos tienen menos de quince años de antigüedad, lo que indica una fuerte correlación entre su nacimiento y los avances en materia tecnológica, lo cual, sumado al peso sobrevaluado de la década del 90, abarató considerablemente los costos de producción de la música. Los sellos estudiados por este autor, no obstante, responderían a una lógica empresarial que no se encuentra en el sello aquí analizado. Mismo, no puedo compartir la primacía analítica otorgada por este trabajo a la edición discográfica, lo cual será desarrollado más adelante.

Como ya explicité a lo largo de esta tesis, realicé un recorrido etnográfico que me permitió conocer de primera mano a dos sellos de la ciudad, en su funcionamiento y dinámica. En ese camino, conocí a músicos pertenecientes a otros de la zona metropolitana, de la provincia de Buenos Aires e incluso de otras provincias argentinas. Pude ser testigo de cómo el dinamismo con el que estos sellos realizan actividades y su multiplicación en los mundos de la música independiente y emergente ha encontrado recientemente un reconocimiento por parte de distintos organismos estatales orientados a la cultura. Así, por ejemplo, el programa de profesionalización estatal con el que realicé trabajo de campo durante el segundo semestre del 2012 planteaba su 
intervención a partir de los sellos y no de la bandas. En este mismo sentido, en el año 2013 el SInCA (Sistema de Información Cultural de la Argentina ${ }^{32}$ ) incluyó en el Mapa Cultural de la Argentina, un relevamiento organizado por la Secretaría de Cultura de la Nación, la categoría "sellos musicales" donde varios de los colectivos que conocí están incluidos. Para esta instancia, analizaré en profundidad la conformación y el funcionamiento de Tigra, incluyendo para algunas dimensiones de análisis el tratamiento del material empírico producido en el trabajo de campo en curso con Concepto Cero y otros sellos de la ciudad.

Tigra, sello identificado con el universo del indie, nace a fines del año 2004, siendo en este sentido un sello pionero en la ciudad de La Plata, ya que la mayoría de los sellos de la ciudad de La Plata han iniciado sus actividades más tarde, especialmente después del 2009. En cuanto a Tigra, si bien su nacimiento puede fecharse en 2004, quienes participaron de esos inicios ya compartían actividades diversas al menos desde comienzos de la década: bandas que se armaban y desarmaban a un ritmo frenético, fechas, fanzines, pero también asados, veladas de lectura, salidas nocturnas, reuniones para "jugar a la play", viajes de vacaciones. El sello habría empezado como un "juego", en el sentido de algo que no se tomaban "muy seriamente" pero también en el de una vinculación con la música que privilegia la diversión y el disfrute. Claro que en ese momento de sus trayectorias no podían plantearse mucho más. No obstante, la aspiración y convicción de "sacar discos de verdad", es decir no en CD-R, como de hecho hicieron en los comienzos, siempre fue muy fuerte. La decisión de empezar a editar en $\mathrm{CD}$ es presentada como una forma de autorrealización, de superación en una trayectoria, pero a la vez como el resultado de una estrategia consciente, ya que de acuerdo a ellos los fabricados de manera industrial posicionan de otra manera a las bandas, especialmente con respecto a la prensa, un actor considerado fundamental.

El nacimiento de Tigra coincide con la edición del primer disco, no multicopiado, en CD-R, sino "fabricado" (es decir, replicado) que edita una de las bandas, viable gracias al abaratamiento de costos que implicó asociarse a la $\mathrm{UMI}^{33}$.

\footnotetext{
${ }^{32}$ Ver: http://sinca.cultura.gov.ar/

33 La UMI (Unión de Músicos Independientes) (http://www.umiargentina.com/umiargentina/) es una asociación civil que se sostiene mediante una cuota mensual, brindando a los afiliados beneficios económicos en las instancias de producción, distribución y difusión, además de recursos legales y administrativos, cursos de perfeccionamiento tanto en la técnica musical y sonora como en la gestión independiente de la música, entre otras actividades. Para una historización desde adentro de la UMI puede leerse Lamacchia (2012). El costo final de edición de un disco, según datos de Carnicer (2008), se reduce alrededor del $30 \%$ en relación a los valores de mercado. En el período que realicé mi investigación, y también actualmente, la tirada mínima requerida es de 1000 copias.
} 
Después de este primer lanzamiento, el resto se convenció de que el proceso "valía la pena", especialmente por las puertas que se abrían en Capital Federal y la atención cada vez mayor que el periodismo y el público de allí les prestaba. Entonces, todos comenzaron a sacar sus propios discos elaborados de forma industrial, si bien algunos aún alternan con otros en CD-R. Especialmente a partir de la notoriedad alcanzada en Capital Federal, y de allí en otras zonas del país, reconocen que empezaron a manejarse de una manera más prolija, a considerar cosas que antes no tomaban en cuenta, como el diseño, la actualización y el mantenimiento de la página del sello, la prensa referida al mismo, etc.

En sus orígenes, el sello se pensó como una cooperativa, una cooperativa de bandas "amigas", donde cada una aportara "según el nivel de independencia o pobreza". Cuando Verónica recordaba aquella época refirió a la idea de "un sello que pudiera permitir la producción de discos sin tener que poner plata propia." Se intentó dicha estrategia brevemente, pero "Nunca funcionó. ¿Qué le voy a pedir al sello?, son los chicos de otras bandas, todo bien, pero no le puedo pedir plata a los chicos para sacar un disco, porque podrían sacar el de ellos..."Joaquín aclaraba que "no hay plata" y que el grabado de los discos por lo general los financiaba cada banda, asegurando el colectivo la prensa y la distribución. Otros miembros, no obstante, se permitían proyectar un poco más al respecto: "En algún momento, cuando todas las bandas triunfen y podamos vivir de la música y podamos juntar plata ahí va a ser un sello discográfico que edite discos.”

Mientras yo realizaba mi trabajo de campo, el sello contaba con dieciocho “artistas activos" y al menos otros siete que habían pertenecido a él en algún momento, un conjunto formado en su mayoría por proyectos anteriores y disueltos de músicos que siguen moviéndose en sus órbitas. Hasta mayo de 2013 editaron sesenta y cuatro discos ${ }^{34}$, entre ediciones físicas y virtuales, muchos de ellos co-editados con otros sellos pequeños de la zona metropolitana que suelen ser identificados también con el indie. En los últimos tres o cuatro años, de la mano del éxito de una de sus bandas más importantes, las bandas del sello y bandas cercanas, "amigas", pero no editadas por él, experimentan un crecimiento considerable, como también un desplazamiento de un lugar periférico en la agenda a uno más central, manifestado en varios hechos que cualquiera dentro de la escena independiente, no sin recelos, referencia. Primero, la

\footnotetext{
${ }^{34}$ Para dar una idea de la magnitud relativa de este número por vía de la comparación, en la muestra de sellos nacionales de Luchetti (2007), el 37,9\% no supera los treinta títulos, mientras que un 15,5\% (en rigor, nueve sellos) ha publicado más de ciento cincuenta. Dentro de los sellos relevados por Vecino (2011), los números absolutos de ediciones oscilan entre doscientos cincuenta y dieciocho.
} 
apertura y mantenimiento de un circuito de presentaciones en la vecina ciudad de Buenos Aires, acompañada de la participación en festivales de música alternativa en otros países y/o junto a bandas de proyección internacional. Segundo, la sucesión de tapas y artículos en publicaciones de circulación masiva, como los suplementos Si y No de los diarios Clarín y Página/12 respectivamente y las revistas especializadas Rolling Stone y Los Inrockuptibles. Tercero, la fuerte presencia en las redes sociales de Internet. Cuarto, y entre otros, la consideración de estos artistas por parte de la municipalidad local, el Gobierno de la Ciudad de Buenos Aires y el gobierno de la provincia de Buenos Aires en sus eventos diseñados para un público definido como joven, entre demás inclusiones en proyectos (festivales, discos, ciclos de conferencias, etc.) que impulsan recientemente organismos estatales como el Instituto Cultural de la Provincia de Buenos Aires y la Dirección de Industrias Culturales de la Nación.

Al comienzo del trabajo de campo con Tigra, imbuida de la idea de sentido común de un sello discográfico como una organización con una estructura más o menos establecida de toma de decisiones, una de mis primeras sorpresas fue percatarme que no era tal cosa. El sello no tiene una sede física ni tenía cuando yo trabajaba alrededor de él una dirección legal. Tampoco cuenta con personas que realicen siempre unas determinadas tareas ni cumple reuniones regulares donde se tomen decisiones. Mientras yo realizaba mi trabajo de campo, Joaquín se encargaba de los trabajos de difusión requeridos, en especial del manejo de las cuentas de Facebook y del mantenimiento de la página web oficial, como de contestar las notas de prensa. Sobre el resto de las actividades me decía, "ahora no hay nadie específico. Si hay alguien que va a hacerlo por su banda, después nos intercambiamos el favor pero no hay nadie que lo haga..."

De la misma manera, las decisiones (sumar nuevos proyectos, realizar un festival del sello, cambiar la página web) se sucedían más que nada en ámbitos cotidianos, tramadas en las redes de un grupo donde existían núcleos y periferias móviles y afinidades más fuertes con unos que con otros. No se organizaban reuniones específicas, cuando le pregunté a Joaquín por ellas me contestó: "Una vez convoqué a una reunión pero estaban todos borrachísimos", dando a entender que nadie se lo tomaba muy seriamente. En su lugar, las salidas de fin de semana, las reuniones en las casas de los amigos, las previas de los recitales eran los ámbitos habituales en los que, entre otras conversaciones cotidianas, se hablaban asuntos del sello. En este sentido, Mariano, muy ocupado por entonces en cuestiones académicas, entendía que no estar muy presente en las salidas lo excluía de las tomas de decisiones. Verónica, bajista de un grupo, alejada 
por cuestiones sentimentales de las redes de amigos del sello, me comentaba de su incomodidad a la hora de compartir espacios con los chicos de las bandas, mientras sostenía su presencia en el grupo por Facebook. Es claro que estamos ante un caso cualitativamente distinto al de otros sellos independientes argentinos, incluso PyMEs, con una estructura de gestión más o menos consolidada. Sin embargo, dicho año el sello no dejaba de aparecer periódicamente en la prensa, de armar fechas, de editar discos y de sumar amigos.

El sello tampoco se puede entender como una empresa a la manera en que esta es planteada por algunos abordajes locales, por ejemplo el de Palmeiro (2005). Su trabajo encuentra en los sellos independientes locales pequeñas y medianas empresas (PyMEs), si bien reconoce que no siempre están constituidas como tales frente al fisco. Las describe como compañías productoras de fonogramas que no son propiedad de las grandes transnacionales y que tienen una estructura simplificada, menor tamaño y escaso poder financiero en relación a ellas. Piensa a sus propietarios y promotores como pequeños ejecutivos, muchas veces faltos de profesionalismo y restringidos por lo tanto en sus capacidades de acción dentro de la industria de la música. Este vocabulario económico no cuadra con Tigra ni tampoco con el resto de los sellos abordados en mi trabajo de campo, alejados de ese tipo de definiciones y perspectivas con respecto a su práctica musical, incluyendo la práctica de gestión. En realidad, Palmeiro (2005) analiza experiencias de producción musical y discográfica con unos parámetros y una idea general de sello que pertenecen al paradigma del imperio de las grandes compañías, en el que el disco inicia el ciclo de la música (Fouce 2012). En una lectura superficial, el caso que aquí se describe puede ser confundido en dicha matriz: los músicos usan la misma palabra (sello) para referir a una realidad diferente. Sin embargo, mientras las compañías y sellos de la industria discográfica, presentan una orientación básicamente mercantil, los músicos emergentes que acá analizo disponen sus sellos más hacia la creación y sostenimiento de comunidades interpretativas, el trazado de redes de sociabilidad y la producción del saber social como modo de activación de oportunidades de vida. Esto no significa que el sello resulte ajeno a una operación de ventas: no es que los discos editados no pretendan venderse ni que el deseo de ganar dinero no descanse en el horizonte de expectativas de los sellos (y también de algunas bandas) pero no es el lucro su orientación principal en esta instancia de su desenvolvimiento.

Por otra parte, Tigra no tiene una política de descubrimiento de nuevos artistas con el propósito de sumarlos al catálogo. Joaquín se encargó de dejármelo muy claro 
cuando me dijo "yo no soy un band hunter" 35", para luego contar de los "veinte mails por semana pidiendo entrar", dando a entender que la mayoría ni los contestaba. Otro músico afirmaba: "Muchas bandas dicen 'yo quiero formar parte', y yo he visto, mandan mails, dejan comentarios en Internet, y te ponen 'yo soy de una banda de Florencio Varela y quiero pertenecer al sello para sacar un disco' (...). A esa persona hay que explicarle que no le vamos a pagar un disco". Pero también a esa persona habría que explicarle que la inclusión en el sello está mediada por una categoría, la de amistad, donde las afinidades morales y estéticas se piensan desde ella. Así, en los casos con los que tuve contacto, el reclutamiento de artistas no tiene lugar gracias a prácticas específicas de búsqueda y descubrimiento sino a partir de redes de personas ya conocidas. Esto diferencia nuestro caso de otros sellos de la zona metropolitana, por ejemplo los que Vecino (2011) llama cosmopolitas, donde según su trabajo sería posible observar una estrategia de formación de catálogo a partir de líneas estéticas muy cuidadas que orientan los descubrimientos musicales.

También para el contexto local, Corti (2007) propone dos modelos dominantes en las redes del disco independiente: el del productor/empresario de riesgo que asume la producción del material, por lo general, pero no siempre, a partir de sellos con una fuerte política de mercado, y el de los sellos que ofrecen la apoyatura comercial, legal y de distribución, quedando a cargo del artista la producción y financiación del disco. El caso pionero de Mandioca, con el cual muchos de los actores que producen música indie manifiestan una identificación conceptual (Peña Boerio 2011), es propuesto por Corti como un ejemplo que responde a los lineamientos del primer modelo. Mandioca se proponía como una editora de discos alternativa que tomara en cuenta las propuestas de los músicos, conservara cierto control del proceso de producción desde la grabación hasta la distribución y conjugara la perspectiva de ventas con los criterios de calidad y pertenencia al mundo del rock, ya que las grabadoras oficiales de la época aún no podían ver en él más que un dudoso negocio, para no hablar de la incomprensión que manifestaban con respecto a sus concepciones estéticas (Díaz 2005). La infraestructura de Mandioca era muy pequeña, el proyecto se financiaba a partir créditos y pagarés y sus socios no cobraban salarios, ya que procuraban, por el contrario, una reinversión permanente destinada a nuevos grupos y sus proyectos (Collado 2010).

\footnotetext{
${ }^{35}$ Refiere a algo así como un descubridor de bandas, sin embargo no es una expresión especializada de este campo ni tampoco una usada en lengua inglesa.
} 
A diferencia de este caso histórico, los nuevos sellos que surgen en la zona metropolitana entre los años 1998 y 2010 no suelen proveer a los artistas de estudios de grabación, equipos, instrumentos o recursos humanos, como establece Vecino (2011) al respecto de los mundos del "rock independiente", la "cumbia electrónica" y el "nuevo tango". Al contrario de Mandioca, que quebraba a mediados del año 1970, luego de dos breves pero intensos años de actividad en los que intentó el éxito de ventas de alguna placa para asegurar su supervivencia, sellos como el que acá estudiamos asumen en comparación muy poco riesgo, lo que les permite un mayor dinamismo y el funcionamiento con rendimientos económicos que para otros resultarían un verdadero fracaso comercial. En nuestro caso particular, además, no es posible afirmar que el sello se encarga de los gastos que implica una apoyatura comercial, legal y de distribución, ya que los trámites legales, la política de distribución (propia o terciarizando el servicio) y la venta pasan, en diferentes grados, por las propias bandas. El sello no posee las estructuras típicas de gestión, ni los recursos económicos, que permitirían hacerse cargo de estas dimensiones de la actividad, pero sin embargo no es ajeno a dichas tareas típicas, ya que funciona como centro de redes de sociabilidad de producción musical en las cuales dichas actividades, pero también otras que un observador externo separaría de la música, tienen lugar. A estas tareas pueden sumarse la prensa, la promoción, la representación de artistas, la organización de eventos y hasta la propiedad de estudios de grabación, todas áreas de diversificación empresaria aisladas por Luchetti (2007) para los productores fonográficos "independientes", concentrados mayormente en la capital del país. En nuestro caso, estas áreas son cubiertas por los amigos o por la "familia" del sello, nociones con las que referían a dichas redes sobre las que en breve se profundizará.

A partir de esta construcción empírica, en diálogo con la bibliografía especializada, fue volviéndose claro que al caso en estudio le quedaba grande la categoría de sello discográfico independiente en la bibliografía citada, a la vez que la desbordaba. Esta situación nos habla de un nuevo momento en la producción discográfica y musical en el más amplio sentido, producto de transformaciones tecnológicas, mercantiles y sociales. En este sentido, la descripción de Tigra se propone como una condensación histórica singular que puede poner en escena de forma ejemplar estas transformaciones. 


\section{Un grupo de amigos}

Poco a poco fui dándome cuenta que el sello era más que nada, como ellos mismos decían, un "grupo de amigos" que era además "un grupo de gente que hace cosas”. Que el sello no tenga sede física no implica su virtualidad, ya que existen redes y espacios, físicos y concretos, donde el sello es producido como tal, por más que estas redes sean de "amistad" y estos espacios las casas particulares de los sujetos. Contaba Joaquín, "cuando alguien está por sacar un disco, como todos somos amigos, vemos, discutimos, nos preguntamos miles de veces las cosas antes." En este marco, el amigo es el "socio" de un proyecto como el sello, es el que pone plata para un disco, es el coequiper, el co-compositor, el compañero de banda, etc. En este sentido, los amigos no lo son porque se encomienden mutuamente sus penas y alegrías, si bien esto también sucede y como vimos muchos se conocen desde la adolescencia, sino que los amigos son amigos porque comparten de alguna manera "las propias reglas" del trabajo artístico. En este sentido, he observado que quienes se han sumado al sello, no formando parte del núcleo fundador original, refieren dicha inclusión desde esta categoría. Un músico me decía que el hecho de tocar con bandas del sello y luego comenzar a ser editado por él lo había vinculado con chicos y chicas que se volvieron sus amigos. Esta característica del grupo de amigos llegaba a su paroxismo cuando Joaquín decía que "es un grupo de amigos grande y subdivido en bandas, pero es bastante casual la división entre bandas", queriendo sugerir que podrían intercambiarse roles. En los ocho años que transcurrieron desde su formación, el grupo siguió privilegiando la amistad a la hora de incorporar nuevas bandas, amistad basada en afinidades en un modo de encarar la escena y la industria musical: ese modo más relajado.

Resulta pertinente pensar al grupo de amigos en los términos de un mundo del arte (Becker 2008), una red de personas cuya actividad cooperativa, organizada a través de un conocimiento conjunto de hacer cosas, produce trabajos que un grupo dado define "artísticos". Esta actividad cooperativa es positivamente ampliada por la presencia prácticamente permanente de Internet en las vidas de estos músicos. Producen para el sello conectados a las redes sociales: definen eventos y sus características por chat, arman presupuestos en archivos compartidos de Google Docs, combinan encuentros por Facebook y Twitter, realizan propuestas para el sello en grupos privados de Facebook, etc. Por mucho tiempo, en las reuniones, recitales y eventos a los que concurría 
(organizadas por mail, Twitter o Facebook) me daba cuenta que muchas conversaciones se arrastraban de chats o de interacciones en las redes sociales que habían ocurrido en la semana. Logré un avance importante en este sentido cuando fui poco a poco haciéndome "amiga" de los músicos en Facebook. Debe aclararse que esto no implica que nos hallemos separados unos de otros o que el contacto cara a cara no sea importante, sino que estas tecnologías son coextensivas a las prácticas de producción musical. En este sentido, retomo de Welschinger (2013) una noción de las redes sociales como plataformas que operan de manera cotidiana a la manera de un dispositivo de gestión del grupo de amigos, gestión en este caso de las actividades conjuntas que estos amigos apuestan en la música.

Este mundo del arte encuentra su núcleo duro en los artistas del sello y los amigos con las que se comparten fechas, salas de ensayo, estudios de grabación, equipos, como también contactos e información. Es decir, los participantes de los diferentes proyectos suelen trabajar en conjunto, produciendo unos para otros: se trata de programar los eventos, contactar e invitar a otros a participar, tratar con los empresarios y/o encargados de los locales, difundir sus presentaciones, a la vez que grabar discos, diseñar sus tapas, llevar la grabación a la fábrica, elaborar los afiches, etc. Es habitual ir a un recital y que un músico de otra banda, algún amigo o pareja, cobre las entradas, o bien haya prestado algún instrumento o se haya encargado de diseñar el flyer. Asimismo, en los créditos de los discos puede leerse cómo quienes tocan en una banda, producen la gráfica del disco de otra, o hacen participaciones en calidad de músicos invitados, la mayoría de las veces de forma no remunerada en moneda, e incluso si cuentan con estudios, más o menos sofisticados, los prestan o intercambian por otros bienes (publicidad en una fecha, por ejemplo). Estas formas de trabajo autogestivas y grupales refieren a toda una modalidad de producción musical, son la regla, como ellos dicen, "las propias reglas", y no la excepción.

Sin embargo debe considerarse que "las propias reglas" y su hincapié en la "buena onda" y la "colaboración", rigen para los definidos amigos y no tanto para otros con los que puede llegar a compartirse una fecha, un compilado o cualquier otra actividad. Algunos entrevistados se mostraban poco propensos a la integración y colaboración con esos otros: "son pocas las bandas con las que se pueden compartir cosas", me decía un miembro que se ocupaba de la prensa del sello. Por otro lado, en un par de recitales, pude observar cómo el grupo de amigos compartía instrumentos entre sí pero había pedido a la otra banda con la que se compartía fecha, cuyos miembros no 
formaban parte de sus redes más cercanas, que pusiera la batería -costosa y más difícil de transportar que los otros instrumentos- y algunos equipos. Uno de ellos, sabiendo de mi investigación, se me quejaba abiertamente mientras se sucedían las presentaciones, intentando poner en tela de juicio esa retórica de la amistad que no lo favorecía. Estas situaciones, sin embargo, que afectan a todo lo que se trama y se significa alrededor de la idea de amistad en este campo, no fueron recurrentes en mi trabajo, lo que en parte dificultó una construcción más densa al respecto del trazado de límites entre los que son amigos y los que no.

En segundo lugar, la categoría de los amigos se extiende hacia otros productores, que no dejan de hacer de público del circuito: fotógrafos, diseñadores (gráficos, de ropa, de objetos), escenógrafos, ilustradores, videastas, Djs y Vjs, dibujantes, participantes de colectivos culturales diversos y periodistas, bien de suplementos jóvenes, de radios de "rock" o de sitios de Internet de referencia de la escena. Estos actores, la mayoría de los cuales vive profesionalmente de su actividad en otros mundos de la práctica no muy alejados del que aquí presento, producen muchas veces "de onda", por remuneraciones no monetarias o por menos dinero del que ganarían, dada su afinidad moral y vinculaciones afectivas de diverso tipo.

Dentro de las relaciones con un otro significativo moduladas a partir de la categoría de amistad, destacan las que se tienen con quienes ejercen el periodismo o la crítica, puesto que participan en la constante redefinición del indie que marqué en el apartado Indies e independientes y ponen en circulación los relatos del valor de la música que se produce. Para el sello en cuestión, hay que contar primero la radio y la prensa autogestionada de la ciudad, que da cuenta plenamente de estas tramas de cooperación descriptas. En esta tarea destaca la frecuencia modulada de la Radio Universidad, dependiente de la UNLP. Se presenta a sí misma como una radio college, filiándose con las emisoras de las universidades norteamericanas, definidas como radios de autor y cruciales en la historia del indie de aquel país (Waits 2007). La misma relación a partir de la idea de "amistad" aparecía para ciertos periodistas porteños, involucrando no sólo las revistas de tirada nacional ya mencionadas en páginas anteriores, sino muy especialmente a revistas on line; sites de noticias, crítica de discos y entrevistas; archivos de aficionados e infinidad de blogs más o menos ignotos, que por la propia lógica de la circulación y organización de la información en la escena independiente, muchas veces tienen las primicias. Todos estos amigos son asistentes habituales de los recitales, algunos también organizadores, configurando una situación 
que se asemeja a la que refiere Seca (2004) para el contexto "underground" francés con la noción de público hermano: un grupo percibido por los artistas como exigente, compuesto por "expertos" y cuyo juicio es determinante, ya que da el renombre necesario.

Finalmente, esa sustantivación es desplazada laxamente por los propios músicos al resto de los participantes, aquellos que en otros mundos musicales aparecen como fans o seguidores. Estos son poco numerosos en términos numéricos pero significativos en cuanto a su actividad, ya que la gran mayoría se halla de alguna forma involucrada en actividades que producen la escena: suben información, fotos y videos a comunidades virtuales diversas -YouTube, MySpace, Vimeo, LastFm, Facebook, Twitter, etc.-; escriben blogs; promocionan los eventos; ponen a circular el material discográfico para su descarga gratuita; etc. Este público se nutre básicamente de los universitarios de la ciudad, tanto de La Plata como del interior del país y, al igual que en el indie porteño (Peña Boerio 2011), comparte el rango etario con los músicos, considerándose par de quienes en ese momento están en el escenario y manteniendo una relación desde esa simetría con ellos.

Ahora bien, ¿cómo puede vincularse este tipo de lazo con las relaciones que tuve que desarrollar para investigar desde una perspectiva etnográfica? Dado que los sellos se plantean como grupos de amigos y en este hacer música en conjunto, los amigos comparten de alguna manera "las propias reglas" del trabajo artístico, ¿cómo tramité mi participación en relación a mi posición de investigación y también de género? Como ya fue descrito, en este mundo las mujeres "amigas" (muchas veces vinculadas sentimentalmente a los músicos) suelen asumir tareas tras bambalinas (fotografía, escenografía, diseño de flyers, taquilla), mientras que los varones se orientan a actividades más visibles y jerarquizadas (generalmente arriba del escenario). En esta situación, mis primeras actividades con el sello tuvieron que ver con "hacer la taquilla" o vender discos en los distintos eventos. Esta fue una manera de empezar a hacerme "amiga" en el sentido propio del grupo ya especificado, acorde a mi posición de género, posibilitado en parte gracias al interés y la poca reactividad que produjo mi condición de "socióloga", y acomodándome a estas "reglas", ya que se daba por sentado que yo me encargaría de ese tipo de tareas "de onda", compartiendo un sentido de la producción autogestiva con ellos (sin que nadie ignorara que yo también encontraba en esas tareas una forma de "devolver" el permiso otorgado a mi investigación). 
En resumidas cuentas, de acuerdo a los desarrollos que permitió el trabajo realizado, la categoría de la amistad tiene una significación especial en este campo: no responde necesariamente a una amistad emocional e íntima (si bien esta puede manifestarse) sino a un lazo personal basado en la proximidad estética y ética. En este sentido, los amigos no lo son porque se encomienden mutuamente sus penas y alegrías, si bien esto en algunos casos particulares también sucede. La amistad, más bien resulta una forma de capitalización social para los músicos y productores estéticos a la vez que una forma de articular moralmente su mundo musical. En el primer sentido la amistad refiere a las redes, conexiones y contactos, como parte de la organización y del sostén en la práctica de hacer música. Es lo que Gallo y Semán (2013) conceptualizan como una "cooperación interesada" en la complicidad en un proyecto difícil: "vivir del arte". En el segundo sentido, generalmente el más resaltado por los músicos, la amistad debe entenderse a la manera de un compartir las propias reglas del trabajo artístico: en este sentido, los amigos son amigos porque se saben afines en una manera específica de ser músicos, de ser artistas.

Si bien la idea de amistad no suele ser problematizada en los trabajos académicos especializados sobre música, puede encontrarse sugerida y/o mencionada en muchos de ellos. Especialmente la primera dimensión aquí construida puede encontrarse en el trabajo de Becker (2009) sobre los músicos de baile en los Estados Unidos, cuya investigación fue iniciada a fines de la década del cuarenta (Becker 2009: 103). Allí es posible leer a sus entrevistados afirmando que "otro modo de tener éxito es tener muchos amigos" (Becker 2009: 127) para connotar las conexiones que son necesarias para conseguir trabajo como músico. Más recientemente, Fouce (2012) en su trabajo sobre música emergente en España sostiene que en este campo es necesaria una red real de amigos y favores para que los proyectos funcionen. Para La Plata, López (2013) sostiene que los espacios culturales que presenté anteriormente, lugares de encuentro para los participantes de la música emergente local, son también muchas veces sostenidos por colaboraciones enmarcadas en redes de afinidades y apoyos de amigos y conocidos. En un sentido más cercano a la segunda dimensión que planteé, Gerber Bicecci y Pinochet Cobos (2012: 55) en una investigación orientada por García Canclini en México afirman que para el caso de las nuevas estrategias creativas todos los proyectos están atravesados por la amistad y la afinidad social: se organizan proyectos con amigos o las personas que trabajan juntas terminan volviéndose amigas. 
De esta manera, tanto el trabajo de campo como las lecturas realizadas indican que contemporáneamente la amistad asume un papel estructurante en distintos emprendimientos musicales y artísticos que se conectan entre sí. Reconociendo esta situación, Quiña (2012) afirma que la amistad en la escena independiente porteña, entendida como un vínculo personal directo basado en la afinidad, oblitera la problemática del empleo y de las condiciones de trabajo. Por mi parte, sin desconocer la existencia de condiciones inestables y frágiles en la producción musical producto de una relación de fuerzas específica al interior de la sociedad capitalista contemporánea, considero que con la centralidad de la amistad estos músicos manejan la precariedad en una práctica, inscribiéndola en una narrativa específica. En este sentido, la narrativa de la amistad no es falsa ni "esconde", al estilo de una falsa conciencia, una situación precaria. Más bien, todo lo contrario: opera en contextos signados por la fragilidad y la incertidumbre, permitiendo en parte el despliegue y el sostén de los proyectos musicales.

Por último, en relación a los usos de la categoría planteados, la referencia sistemática a los amigos en este campo, es decir, la disposición de entender a quienes participan de la producción artística como tales, cuenta con la disolución de las diferencias tradicionales entre los "músicos" y los "públicos". El tipo de lazo que nos presenta este mundo musical nos habla justamente del modo de producción musical que le es característico, un modo que envuelve a todos los participantes en la co-constitución de la música. En particular, el "grupo de amigos" y los amigos tienen su papel tanto en la producción y el sustento económico (o la rentabilidad relativa) de los proyectos como en la consagración artística y en las categorías de apreciación que se utilizan para evaluarla.

En consecuencia, este mundo ya no permitirá su estudio a partir de la distinción clásica entre productores y receptores. En los trabajos locales anclados en la relación entre música y juventud (que se trataron en la Parte 1), el foco estaba puesto en los procesos de apropiación de una obra que se consideraba producida en otra parte, estudiando generalmente "fans", "seguidores", "escuchas" que operaban usos sobre ella -pensados a veces colectivamente bajo la forma de diversas comunidades interpretativas-. La convicción de la eficacia de estos usuarios, contra visiones que de algún modo reivindican las tesis de la industria cultural como manipulación de masas (Adorno y Horkheimer 1997), no había logrado erosionar la fuerte distinción entre la producción y la recepción que seguía organizando dichos estudios. Pero esta diferencia, 
significativa históricamente en el mundo del rock nacional clásico, pierde gran parte de su sentido para la música emergente. Este problema ya fue planteado anteriormente por Semán (2006: 214) para el llamado rock chabón a partir de la idea de una “contraescena" que establecía una nueva relación entre "productores" y "receptores" -si bien es posible que ambas partes de la relación no se acercaran tanto como en el caso que acá se presenta- dando cuenta de un proceso más general dentro de los fenómenos socio estéticos contemporáneos, no circunscripto, como podría creerse, al mundo universitario ni al de las clases medias.

\section{Formas y representaciones del trabajo artístico}

En este punto, podríamos reponer varios relatos que dan cuenta de cómo se trabaja y cómo se representa ese trabajo. Uno, por ejemplo, podría ser el de la realización de un video clip oficial para una de las bandas. Unos chicos de Capital que trabajan en audiovisuales para Pop $\mathrm{Art}^{36}$ se contactan con el cantante de la banda para proponerle hacer un clip. Recuerda Manuel, encargado de algunas funciones en Radio Universidad: "Una vez me escriben los de Él Mató, Chango me dice, 'mirá te presento a los chicos estos, nos quieren hacer un video, si podés dar una mano'." Como la banda se maneja independientemente, razona Manuel, "no tienen una discográfica que les ponga plata, no tenían plata, entonces dije 'bueno, lo pagamos todos nosotros'.” A partir de ello se desata una red de contactos con el fin de hacer el video a costos irrisorios en relación a los valores del mercado. Manuel se percata que en el pueblo bonaerense elegido para rodarlo tiene un "conocido", el organizador de unos festivales de rock, a partir del cual obtiene contactos locales. Así, explica, “conseguí el camping, el lugar para alojarnos, conseguí una casa, pagamos la mitad (...) después conseguí un auto para viajar, viajamos en un auto...". Continúa contando que "Buscando gente que se cope con el proyecto contacté a unas chicas que hicieron el maquillaje de onda". Ellas trabajan para videos de bandas consagradas como Babasónicos, donde les "les pagan un montón de guita", mientras que para esto sólo cobraron los gastos de traslado y de materiales. "Otros pibes dieron gratis para hacer el color, la posproducción...”, mientras

\footnotetext{
${ }^{36}$ Pop Art es un sello argentino de más de veinte años de trayectoria en la industria de la música que tiene en su catálogo algunas bandas asociadas a la escena indie como Banda de Turistas, y otras muy importantes para el rock nacional como Los Auténticos Decadentes, Ratones Paranoicos, Los Tipitos, Árbol, etc.
} 
que el grupo musical pagó un efecto especial. Finalmente, la comida para los días de rodaje fue costeada por un grupo de amigos de la banda. Como vemos, en estas apuestas y en los relatos que las alimentan se percibe una auto-valorización por la "onda" recibida.

Otro episodio involucra la organización de una fiesta para financiar la producción de un disco, por personas del ambiente de la radio, la música y la fotografía a los que les gustaba la banda. Uno de ellos, Manuel, quien también participó en la financiación de otros discos, lo justifica así: "lo hice porque quería y porque tenía buena onda con la banda (...) si lo puedo hacer y después sé que va a volver (...) por ahí a ellos les cuesta un montón juntar la plata y sabés que cuando vendés los discos al principio lo recuperás rápido..." Una tarde, mientras realizaba el trabajo de campo, me llegó un mensaje privado en Facebook, ya que entre mis contactos tengo a la banda. El mensaje reza: "hey amigos, buscamos prestamistas para el disco nuevo, ¿quién se copa?”.

Estas no son historias aisladas: las cosas suelen hacerse así, como dicen "a pulmón", a partir de redes de personas que colaboran, donde "todos se conocen", al menos de vista. Y se hacen "porque sí", "porque quiero", o "porque me gusta", aclarando el dinero que es posible ganar podría ser un estimulante para hacerlo. Como investigadora, yo suelo hacer "taquilla" o "puerta" sin recibir remuneración monetaria, "de onda", dados mis compromisos con el grupo que se presta a mi investigación. A pesar de ello, hay matices muy finos entre lo que se hace "por placer" o "de onda" y lo que ya implicaría un esfuerzo que no se estaría dispuesto a afrontar sin un pago en moneda corriente, lo que depende en gran parte de la capacitación y de las expectativas que la persona tiene con respecto a cómo su trabajo será recompensado.

Volviendo sobre estas descripciones acerca de la forma de trabajo, puede verificarse una relación constitutiva entre las disposiciones morales vinculadas a lo relajado y el funcionamiento del sello. Este modo de producción relajado debe entenderse no sólo como respuesta a una posición subordinada en el campo de la música, sino también como una forma en la que estos actores habitan un espacio de socialización universitario, independientemente de que tengan o no una vinculación con la universidad como estudiantes o graduados recientes. Por más que a veces presenten en las entrevistas sus actividades musicales como un refugio de una vida burocratizada, ello tiene mucho de tópico romántico. No es que la música sea para ellos un oasis de relajación porque su vida es la de ajetreados profesionales, empleados o ejecutivos: la 
actitud "relajada" obedece a una forma de existencia específica, la de jóvenes capitalizados por vía familiar, en el tránsito universitario.

Estas formas colaborativas de trabajo y las retóricas del amor por el arte, no deben opacar el hecho de que este espacio artístico local y regional es en parte mercantilizable bajo la forma de productos concretos, es decir es un espacio que crea un "mercado". Todo ello sucede en el marco de un modo de producción sensiblemente más plural, menos verticalizado y más fragmentado que el de décadas anteriores, donde la gestión se vuelve más que nada una habilidad de los artistas. De esta manera, el "mercado", que clásicamente apareció asociado a la figura de los grandes "pulpos" o las grandes "multinacionales", se constituye en este caso como una multiplicidad de instancias que median con dinero. La relación de proclamada autonomía o dependencia con el mercado, por lo tanto, no es una bifurcación sustantiva: en otras palabras, la llamada "autogestión" (o la gestión del músico o los músicos de sus presentaciones, sus discos, etc.) no se opone al mercado así entendido. Estos cambios en el actual patrón de producción musical son datos de la práctica para estos chicos, figuran en su horizonte de expectativas. En nuestras conversaciones, ellos mismos daban cuenta de "los cambios en la lógica del mercado" o de la "concentración del mercado de los noventa" frente a la fragmentación actual, entre otras problemáticas. Esto no debe hacernos olvidar que, tal como fue expuesto en páginas anteriores, para estos grupos la oposición "artemercado" mantiene cierta validez y sentido, no como una frontera rígida sino a la manera de líneas de fuerza que se trenzan y se confunden.

\section{Los sellos en la producción musical emergente}

De acuerdo a nuestro trabajo de campo con distintos sellos, producto del tránsito en la escena, se podría decir que el resto de los sellos platenses contemporáneos se articulan también gracias a esta lógica de la reunión de amigos, a partir de un círculo de bandas que tocan juntas y un conjunto de personas que trabaja de forma colaborativa, es decir que comparten una posición en una red relacional y ciertos atributos categoriales (Brubaker y Cooper 2001). Se organizan como grupos de amigos en los que cada artista de la red puede aportar algo que el proyecto necesita. Habrá así personas más orientadas hacia la producción, otras hacia el diseño, la grabación, la prensa, etc. Indagados al respecto de cómo definen el ingreso de nuevos proyectos dicen "lo que nos parece interesante a nosotros difundir, lo difundimos"; "las bandas me tienen que gustar", 
"tienen que tener buena música y trabajar como nosotros". Los criterios de gusto estético, de placer y de afinidad en la manera de concebir la música y el trabajo en ella predominan, filiando a estos sellos con otros tipos de emprendimientos culturales que le son contemporáneos. Los sellos, si bien están interesados en operar sobre el mercado de la música, se orientan en este momento de su desenvolvimiento más a "crear una comunidad de oyentes y mejor aún de participantes en el intercambio musical y de estilos de vida" (Yúdice 2007: 53), como las nuevas editoriales que han surgido luego del 2001 en la zona metropolitana aspiran a funcionar en muchos casos como principios organizadores de comunidades de lectura (Vanoli 2009). En ese caso, el editor es también autor y mantiene relaciones de amistad con personas que lo leen, al mismo tiempo, actuales o futuros autores del catálogo (Spilszbarg 2010).

Recapitulando, como decía Joaquín, el sello "no tiene un montón de cosas” pero "tiene un montón de amigos". A partir del trabajo de campo realizado con distintos sellos, procurando articular las características ya mencionadas, puedo plantear una primera aproximación al papel del sello en la producción la música emergente e independiente. El sello funciona como:

-una convergencia de redes de cooperación, a modo de un núcleo que conecta personas y saberes, tanto artísticos, como administrativos y comerciales, necesarios para producir música de forma independiente. Es a partir de estas redes de cooperación que se aprender a grabar, a sacar un disco, a armar una fecha, a tratar con SADAIC ${ }^{37}$, etc. Como me decía Verónica, “aprendí a sacar un disco porque le pregunté a los chicos (...) yo fui y les pregunté (...) 'che, cómo hiciste, ahora como tengo que hacer, cómo lleno la planilla'...”.

-"una estrategia de comunicación conjunta" o una manera, de "enfrentar la escena" con el propósito de "ser más fuerte", en el sentido de la menor dificultad para armar fechas o darse a conocer que sería consecuencia de la reunión. En este sentido, un músico y productor que hace apenas tres años participa de la escena independiente me decía que parte de su motivación para armar un sello había estado en la dificultad para "entrar solo", mientras que cooperando entre un par de bandas las cosas eran más fáciles. Esta estrategia conjunta es también un modo de distinción con otros artistas, como marca identitaria bajo la que se agrupan bandas que se sienten afines. A ello se agrega la

${ }^{37}$ SADAIC (Sociedad Argentina de Autores y Compositores) es una organización sin fines de lucro que reúne a todos los autores y compositores argentinos de música, cualquiera sea su género, en defensa de los derechos de autor. El dinero que se recauda es distribuido entre los creadores de las obras utilizadas, sean estos nacionales o extranjeros. Véase: http://www.sadaic.org.ar 
posibilidad de su funcionamiento como recurso de prestigio: en el caso de Tigra, se trata de estar en un sello de bandas ampliamente referenciadas y precursor para la "escena independiente".

-una forma de "enfrentar el mercado", pero no el "mercado" al que su sensibilidad opone el "arte", ya que el sello activa la formación del tipo de mercado al que ellos mismos aspiran. En este sentido, la reunión exime de ciertos gastos y minimiza otros, ya que, si bien como vimos el sello no financia proyectos musicales a la manera tradicional e incorpora a su catálogo discos ya grabados, mezclados y masterizados, puede hablarse en algún sentido de financiación desde "las propias reglas" del trabajo colaborativo, financiación que abarca tantos los discos como el resto de las cosas que se producen.

Finalmente, tener un sello también sirve para tener otras cosas que conjugan las diversas facetas de los amigos. Durante mi trabajo de campo, Tigra se hallaba involucrado en la producción de un fanzine, como también en eventos de orden puntual: muestras de dibujos, veladas de poesía, musicalización de proyecciones en ciclos de cine. Las bandas del sello, además, estuvieron implicadas en ese período en la producción de la película de una de ellas, que finalmente se estrenó en la edición 2011 del Festival Internacional de Cine Independiente de Buenos Aires (BAFICI). Luego, durante mi trabajo de campo con Concepto Cero, asistí a la producción de un documental que acompañaba un disco colectivo, a la vez que al trabajo previo y conjunto de músicos y Vjs para las presentaciones de las bandas. Al año siguiente, el Instituto Cultural de la Provincia de Buenos Aires lanzaba una serie de videos musicales producidos dirigidos por cineastas del denominado nuevo cine argentino. Estas relaciones con actores de otras artes redundan en el acceso a redes más amplias de producción cultural, las cuales, nuevamente, además de implicar formas de realización personal y relaciones afectivas, suponen una interesante posibilidad de obtener beneficios tanto en dinero como en especie: expectativas futuras que pueden o no cumplirse, currículum, contactos, etc.

Como puede leerse en las páginas anteriores, el predominio de músicos que no sólo hacen música es uno de los rasgos sobresalientes del caso analizado, cualidad que comparten con el resto de la "escena independiente" de La Plata y de la zona (así, contemporáneamente a esta investigación, Quiña (2009b) encuentra la misma característica en la escena de la ciudad de Buenos Aires). En nuestro caso, la interdisciplinariedad debe entenderse en relación a la situación ecológica que confieren las redes universitarias: la dinámica de la vida compartida con otros jóvenes productores 
o potenciales productores artísticos: departamentos, pensiones y casas alquilados en conjunto, clases universitarias, recitales, fiestas, y otros espacios de sociabilidad diurna y nocturna, anclados en una disposición geográfica relativamente pequeña, en comparación con la vecina Capital Federal. Este modo de vida, asimismo, propicia y vuelve central el tipo de amistad que analicé anteriormente: el gestionar y volver real el proyecto musical implica no sólo intercambios repetidos en el tiempo sino también la convivencia dilatada en distintos espacios (Gallo y Semán 2013), que en este mundo musical están dados de antemano y se asientan más que nada en ámbitos hogareños y universitarios.

\section{La moral económica}

En líneas generales, puede decirse que entre los músicos existe la idea de que, en última instancia, tocan por amor a la música, por el placer de pasar un momento con personas que están disfrutándolo tanto como ellos. Todos comparten esa retórica del sacrificio ("no hay plata de nada, es todo a pulmón"), de la solidaridad ("hizo la tapa gratis porque es amigo", "ellos nos cobran más barato, nos ayudan") y del desinterés económico ("está bueno, más que nada lo hago por gusto, porque nunca te va a dejar plata”). Esto no significa que las ganancias no sean importantes o que no existan las preocupaciones monetarias, especialmente entre quienes apuestan a la música como un medio complementario o principal de vida.

En el mes de septiembre de 2010 fui al recital de una banda "amiga" del sello en Cösmiko, una vieja casa reciclada, en 12 entre 71 y 72, de espíritu intimista, paredes íntegramente intervenidas cada mes por un artista distinto, patio con pasto y sillones y "tiendita galáctica" de objetos e indumentaria de diseños únicos. Antes de que tocaran me puse a hablar con Álvaro, egresado de una carrera de cine, quien, según me dijo, se hallaba inmerso en la producción de documentales sobre bandas indies. Al término de su presentación, los miembros de la banda aclararon que su intención original era cobrar una entrada (la cual era de diez pesos, según yo había visto en la difusión del evento en Facebook). Sin embargo, explicaron, como a los primeros asistentes no les habían cobrado prefirieron finalmente no hacerlo con nadie y "pasar la gorra". Nos pidieron que colaboráramos de esta forma con la inminente grabación de su disco. Cuando terminaron de tocar, una chica del público se ofreció a pasar un estuche de instrumento y nos arengaba para que pusiéramos dinero. Álvaro también ayudó en la tarea de 
recolección. Yo puse un billete de diez pesos, ya que había ido con la idea de pagar eso. Un chico puso dos pesos, y Álvaro le dijo que tratara de poner más, el otro le contestó contrariado diciéndole que no contaba con más dinero. Ambos se dedicaron muecas de desprecio. Al término de la recolección la chica le comentaba contenta a una de las músicas de la banda: "Ni una moneda, mirá, ni una moneda".

Ese mismo año, en un recital de la banda más famosa del sello, entre la primera retirada del grupo, su aparición posterior luego del vitoreo de los presentes y la deliberación del grupo en el escenario de cuáles iban a ser los temas a tocar para finalizar el encuentro, algunas voces masculinas unos metros alejadas del escenario vociferaban "quince pesos, Chango [el cantante de la banda], dejate de joder", mientras otros gritaban los nombres de sus canciones favoritas para que las tocaran. Recuerdo que a mí también me había parecido un poco "cara" la entrada. Ya en los años siguientes los precios de los recitales ascendieron, pero los músicos son conscientes de estas evaluaciones al respecto de los precios y en buena medida las comparten.

Entre los músicos que traté, no está muy bien visto cobrar entradas excesivamente "caras", pero también, como muestra el relato de campo al inicio de este apartado, existe un rechazo considerable a no cooperar con la banda y pretender pagar dos pesos por un recital. Cuando estos grupos comenzaron, las entradas que cobraban eran prácticamente simbólicas: bonos contribución de entre dos y cinco pesos. Las locaciones eran otras y sus trayectorias mucho más acotadas. Acompañando el itinerario ascendente de los precios en la economía argentina del período, las entradas comenzaron a subir, pero se mantienen accesibles a lo que pueden pagar los participantes de los recitales. Si bien una puede encontrarse con algunos estudiantes secundarios, la mayoría son jóvenes universitarios fuertemente capitalizados por vía familiar que, no obstante, no tienen liquidez, es decir no cuentan con dinero para consumir (salvo los casos en que trabajan específicamente para ello), por lo que buscan gastar lo menos posible. Tienen suerte: las bandas continúan organizando una cantidad considerable de fechas gratuitas, especialmente los días de menor movimiento y facturación para los bares como los jueves y los domingos.

En cuanto a los discos, circulan para la venta en eventos puntuales: ferias de diseño en las calles, bares o centros culturales, ya sean extraordinarias o regulares; ferias de discos, por ejemplo las organizadas por Radio Universidad, y los mismos recitales, bien en algún puesto al interior del local o incluido en el precio de la entrada. También pueden conseguirse en locales de "diseño", espacios culturales y, claro, en 
algunas disquerías especializadas. Varios sellos han incorporado la opción de la venta virtual, a través de su página web, para retirar la compra en Capital Federal o La Plata, previendo la posibilidad del envío a otros lugares. En Capital Federal y otras ciudades importantes del país, la distribución del material de los grupos platenses está más acotada a disquerías y la venta en recitales. Muchas bandas contrataron a este respecto los servicios de Pop Art que hacen el trabajo por ellos para una red de distribución pequeña -en Capital, diez a quince disquerías- a cambio de un porcentaje sobre el valor del disco. Esta decisión fue tomada por las dificultades que traía el cobro cara a cara, disquería por disquería, y si bien encarece el costo final del álbum, como ellos mismos dicen "en Palermo se vende". A su vez, una vía importante de acceso al disco físico es de mano en mano, a través de relaciones personales con los músicos, los managers, los periodistas, las novias, los hermanos, en fin, los amigos. Finalmente, un porcentaje considerable de la producción (a veces el más alto) se intercambia -por discos de bandas amigas, por prensa en las radios, por reseñas en los medios escritos- o se regala, cosa que me ha ocurrido en la mayoría de las entrevistas.

Puede entenderse cómo estas prácticas no son fácilmente reducibles a un modelo dominante de negocio: los discos circulan por la economía oficial y por las economías informales. No obstante, aunque algunos discos u obras no están registrados en SADAIC, cada vez más estos trámites se hacen, por lo que la gran mayoría están acomodados al régimen de propiedad intelectual dominante. No se trata de producciones e intercambios para-legales, sino de producción y distribución legal, pero por fuera de los circuitos establecidos de la industria masiva.

A su vez, en las consideraciones acerca del intercambio, a cuánto venderlos, dónde, a quién regalárselo, a quién no, se descubren criterios de la moralidad del grupo además de los monetarios, donde hay un dato objetivo que no se soslaya: la demanda no es muy alta. De este modo, Pedro razonaba conmigo: “Entonces la decisión era o agarramos mil discos, llenamos la ciudad de discos y se los regalamos a todo el mundo, o nos quedamos con los 1000 discos en nuestras casas guardados, y vendemos solamente los que vendemos a 20 pesos y recuperamos un poco la plata. En esa decisión, elegimos hacer mixto digamos, como regalárselo a la gente que sabemos que le interesa y que le puede gustar, y los que vemos que van a la mesa de los recitales, y lo miran y lo quieren llevar y sacan la plata del bolsillo, se lo vendemos. Y en las disquerías está para vender." Podría decirse que de algún modo muchas veces se "elige" a quién vendérselo y a quién no. Acá encontramos nuevamente una analogía con las 
nuevas editoriales independientes pos 2001, donde se plantean regímenes mixtos de intercambio que combinan el regalo, la venta y el trueque por otros libros. Como en el caso de la mayoría de los sellos discográficos platenses, en varias de estas editoriales el propósito principal no es ganar dinero, sino poder seguir editando. A su vez, se distribuyen en espacios no convencionales, incluso a veces no se consiguen en librerías (Spilszbarg 2010).

Debe tenerse en cuenta que para estos músicos vender sus discos no es algo evidente, algo que haya que hacer sí o sí, ya que la obtención de réditos económicos se piensa en relación a las presentaciones en vivo. Por más que las ganancias por la venta de discos no sean importantes, si bien tampoco son insignificantes: como dicen ellos "se gana algo de plata", pero principalmente se difunde la obra. Esto nos introduce en algunas discusiones recientes que atraviesan la industria de la música: el carácter prontamente obsoleto del formato $\mathrm{CD}$, las descargas por Internet, la gratuidad o cobro de las mismas, los derechos del autor sobre la obra, etc. En cuanto al sello aquí estudiado, parte del catálogo puede bajarse gratuitamente de su sitio web, a su vez, casi todos los discos pueden conseguirse luego de una buena búsqueda en sitios de descargas como Taringa, blogs personales o redes de intercambio de archivos informáticos como Soulseek. Si bien ellos saben que apenas los discos se consiguen, se cuelgan en la red, también les interesa rescatar el disco en su formato físico, y, más controversialmente, “demostrar que en cierta medida estaría bueno que lo compren”. Joaquín me decía“¿por qué tienen que ser gratis los discos sino es gratis todo lo demás?", un argumento que descontextualizado es igual al de las grandes discográficas, pero que, situado, revela motivos muy distintos: los de una economía moral que preferiría que pagues los discos si podés hacerlo, que ayudes de esa forma a la banda. En este sentido, una vez Mariano me retó porque me había bajado su disco: "No seas rata, los discos [de las bandas independientes] hay que comprarlos". Cabe preguntarse, igualmente, por la ponderación de estas ganancias en su economía global, porque el reto parecía responder también a la propia relación de este grupo con los discos físicos, quizás un tanto nostálgica. Esta valoración se manifestaba tanto en las invitaciones que me hacían para ir a ver a sus casas los discos de la primera época como en expresiones del tipo "tiene que existir el disco, está bueno, yo compro discos" o "te regalaban un disco de la banda que te gustaba y era genial, era la gloria, realmente es valorizar la música desde ese lado, desde que uno le da valor a un disco original”. Esta valoración no resulta contradictoria con la idea expuesta previamente acerca de la relativización del disco en este campo: es menos 
importante en comparación a la mucho más abarcadora sociabilidad musical y estética del grupo de amigos y en relación a la notable preponderancia que adquiere en esta disposición musical el tocar en vivo (y no sólo porque el vivo otorga, según se da por hecho en el ambiente, gran parte de las entradas monetarias).

Para finalizar, resulta interesante retomar la idea de la integración de la vocación con las preocupaciones monetarias, o como dicen Gallo et al (2011), la conjunción de "la guitarrita y las obligaciones". Esta integración resulta novedosa no sólo, como se mostró antes, a nivel del trazado de las trayectorias personales, sino también, como puede notarse en este apartado, a nivel de los discursos: en tanto se habla sobre dinero y en tanto se habla de una manera franca y relativamente desvergonzada. Desde ya, no es que en otros momentos de la producción musical juvenil en nuestro país las bandas no hicieran cuentas ni sostuvieran su viabilidad en ciertos términos económicos. Sin embargo, los diálogos del dinero y de la música no se encontraban integrados en la medida en que lo están en la actualidad, en parte, seguramente, por las características de las construcciones discursivas que acompañaban una oposición entre el "arte" y el "comercio" mucho más estricta.

\section{Los aliados: recursos estatales y gestión}

El último sábado de junio de 2012, en pleno centro de la ciudad de La Plata, alrededor de las $17 \mathrm{hs}$, se daba comienzo a un evento compuesto por dos recitales y una charla en la que participarían músicos de varios sellos musicales y el coordinador de un programa estatal de "profesionalización" de la música emergente. Todos habían sido invitados por los organizadores del evento, miembros de Concepto Cero, sello con el que me encuentro en una continuación del trabajo de campo. Especialmente uno de ellos, Lucas, quien me había insistido para que asista, había devenido el principal promotor del programa entre los músicos y sellos amigos, los cuales luego formarían la red TICA, con la membresía de varios sellos bonaerenses y la participación de Tigra en varios de sus eventos. En la sala donde se realizaría la charla, alrededor de las sillas ubicadas en semi círculo para la ocasión, se encontraban músicos del sello por el cual yo había asistido y alrededor de diez músicos de otros cuatro sellos. Estos cinco sellos, uno 
anclado en City Bell ${ }^{38}$, otros tres en La Plata y un cuarto en pequeñas ciudades de la provincia de Buenos Aires, habían iniciado sus actividades entre los años 2009 y 2012.

Mi trabajo de campo con Tigra, y luego en Concepto Cero y los sellos de la red TICA, es contemporáneo al creciente interés que distintos organismos y agentes del Estado comenzaron a prestar a estos músicos y sus proyectos. Si bien no es el objeto de esta tesis presentar este proceso, debe tenerse en cuenta que las condiciones de estas progresivas relaciones entre el Estado y los productores de mundos del arte musicales no se crearon de la noche a la mañana. Por un lado, se despliega un movimiento que tiene que ver con la expansión de las industrias culturales a nivel global y la valorización de la cultura como recurso por parte del Estado, de acuerdo los lineamientos de importantes entidades internacionales como la Unión Europea, el Banco Mundial (BM) y el Banco Interamericano de Desarrollo (BID) (Yúdice 2002). De acuerdo a estimaciones de Miguel (2012), alrededor del año 2000 comienza en Argentina la implementación sistemática de políticas públicas específicas para las diferentes "industrias creativas" (diseño, cine, música, teatro, entre otras) en los distintos niveles de gobierno, junto al establecimiento de instituciones dedicadas en forma plena a su estudio. A grandes rasgos, es en este contexto que hay que inscribir a proyectos como MICA, BAFIM (Buenos Aires Feria Internacional de Música) o FIFBA (Festival Internacional de Folklore de Buenos Aires). Esta situación va acompañada de cambios muy visibles en los perfiles de los funcionarios del sector, orientados ahora más hacia la gestión que hacia la alta cultura. Por el otro lado, en Argentina, luego del estallido de 2001, se produce un movimiento, visible pero de difícil ponderación, de los músicos y la música autodenominados “independientes" hacia el espacio público (Lamacchia 2012, Quiña 2012) que explicaría en parte su crecimiento.

Así, mientras yo iba a sus recitales, varias bandas de Tigra eran incluidas en Catálogo Rock ${ }^{39}$, una plataforma/muestreo de artistas bonaerenses compilado por el Instituto Cultural de la Provincia de Buenos Aires que publicó su primer disco en el año 2011 a partir de canciones editadas con anterioridad de algunas bandas independientes e indies de la provincia. Asimismo, durante los años 2011 y 2012 vería aparecer las bandas y sellos de estos músicos en varios proyectos y eventos organizados por distintas

\footnotetext{
${ }^{38}$ Localidad dentro del Partido de La Plata, ubicada al noroeste del centro de la ciudad de La Plata.

${ }^{39}$ De acuerdo a su presentación oficial, Catálogo Rock (o el Catálogo de Sellos de Rock de la Provincia de Buenos Aires) se piensa como "una puerta de entrada para trabajar con (...) artistas, sellos, productoras; y PyMEs en distintas plataformas de promoción, visibilidad y desarrollo, pudiendo participar en distintas instancias de conciertos-vivos y obtener asistencia técnica y financiera, entre otras cosas". Ver: http://www.folkloreba.com/notas/825-Se-viene-el-3-Catlogo-de-Artistas (consultado: 24/04/13).
} 
instancias del Estado: los recitales de la Dirección de Juventud de la Municipalidad de La Plata, las grabaciones del Instituto Cultural en el estudio del Pre MICA ${ }^{40}$ Buenos Aires para la edición de un disco físico, las rondas de negocios y las charlas/conferencias de los distintos pre MICA regionales en varias provincias del país, una serie de videos musicales producidos por el Instituto Cultural y dirigidos por cineastas del denominado nuevo cine argentino, entre otros.

De esta manera, todos estos sellos tenían o habían tenido algún tipo de relación con instituciones estatales en alguno de sus niveles municipales, provinciales y nacionales. No todos con la misma cercanía, con el mismo interés o con la misma comodidad pero para ninguno era un actor desconocido en su práctica musical. Estas relaciones, ya sea a partir de la convocatoria pública (como en el caso de Catálogo Rock) o del contacto personal a través de redes (como en el caso del disco del pre MICA y de los eventos mencionados), habilitan la obtención de recursos y prometen ciertas posibilidades que resultan significativas para la instancia de las trayectorias de los músicos que trato. Recursos: no tanto bajo la de dinero (si bien existen subsidios y fondos que algunos han obtenido) sino bajo la de objetos necesarios como equipos de sonido, gráficas, escenografías, escenarios y demás. Posibilidades: de actuación, de difusión, de producción, de retribución monetaria, entre otras, que podrían resultar de mucho más difícil obtención si el Estado no interviniera. No obstante, junto a estos recursos y posibilidades es posible encontrar muchos conflictos prácticos, malentendidos y tensiones en los propios proyectos en los que mutuamente músicos y gestores estatales se involucran.

Acompañando durante el año 2012 las capacitaciones de este programa específico de profesionalización ${ }^{41}$ de colectivos musicales organizado por la Secretaría

\footnotetext{
${ }^{40}$ Refiere a un encuentro regional previo, en el año 2012, de la edición 2013 del MICA (Mercado de Industrias Culturales Argentinas). Organizado por la Secretaría de Cultura de la Nación, conjuntamente con el Ministerio de Industria, el Ministerio de Relaciones Exteriores, Comercio Internacional y Culto, el Ministerio de Trabajo Empleo y Seguridad Social, el Ministerio de Turismo y el Ministerio de Planificación Federal, Inversión Pública y Servicios, el MICA se plantea como "el primer espacio en la Argentina que concentra en un mismo lugar, las diferentes actividades de las industrias culturales con el objeto de generar negocios, intercambiar información y presentar su producción a los principales referentes de todo el mundo. Los sectores que participan son: artes escénicas, audiovisual, diseño, editorial, música y videojuegos", de acuerdo a datos de su página oficial: http://www.mica.gob.ar/institucional/ (consultado: 24/04/13).

${ }^{41}$ En el campo que acá trato, las referencias a lo "profesional" se revelan polisémicas y entrecruzadas. Para los músicos, puede decirse que un sentido se funda en el "vivir de la música" (es decir, originar recursos que permiten acceder total o parcialmente a medios de vida), otro sentido se vincula a la formación musical más o menos dedicada (no necesariamente escolarizada o institucionalizada), un último sentido (en esta enumeración) tiene que ver con gozar de mejores condiciones para la perfomance
} 
de Cultura de la Nación, puedo plantear a modo exploratorio algunas pautas de relación entre el Estado y estos músicos, a los fines de ponderar la importancia que para ellos toma la gestión y la resignificación que en este proceso asume la categoría de independencia, lo cual será discutido en un siguiente apartado.

El programa en cuestión fue presentado esa tarde por Mariano, encargado de la programación de las bandas de Tecnópolis ${ }^{42}$. Mariano no llegaba a los cuarenta años y era la primera vez que se encontraba "trabajando para el Estado", contando con una trayectoria como manager de bandas de rock "alternativo" en los años noventa, además de una circulación importante en FM La Tribu, un colectivo de comunicación alternativa radicado en la Capital Federal reconocido por su trayectoria y activismo cultural. Mariano relató que en Tecnópolis habían hecho un par de fechas con "bandas grandes" (y refirió como ejemplos a Kapanga, Bersuit y La mancha de Rolando), pero que también resultaba una buena idea que "todos puedan ir a tocar a Tecnópolis", especialmente las bandas "independientes", que así podrían presentarse en un "escenario profesional". Sin embargo, ya habían programado a un par de este tipo de grupos para percatarse de que éstos solían no manejar ciertas cuestiones técnicas de la ejecución musical en esa clase de escenarios. Así, Mariano planteó que había reflexionado y concluido que en parte su tarea como funcionario del Estado era formar a dichos artistas, presentando de esta manera el nacimiento del programa de profesionalización. Luego, narró algunas experiencias en sus viajes al interior del país, ya que el criterio del programa era federal, para explayarse en lo que pretendían lograr: un ida y vuelta entre las propuestas de los músicos y el programa, materializada en distintas tutorías y "charlas técnicas" como también en dinero, pasajes, y otras cosas que se necesitaran y pudieran brindarse. El objetivo declarado a mediano plazo era empezar a desarrollar circuitos culturales que no dependieran de la Capital Federal. Inspirada en parte en otras experiencias de trabajo en red y producción cultural, como la brasileña Fora do Eixo ${ }^{43}$ la propuesta declarada tenía entre sus objetivos inmediatos amplificar la unión de fuerzas que ya de por sí se daba en los sellos y colectivos musicales.

de la música en vivo (sonido de amplificación, asistentes de escenario, etc.) y para la grabación, mezcla y masterización de los materiales sonoros.

${ }^{42}$ Se trata de una megamuestra de ciencia, tecnología, industria y arte emplazada en el Gran Buenos Aires, inaugurada en 2011 por la Presidencia de la Nación. La entrada es libre y gratuita. Ver: http://www.tecnopolis.ar/2012/

${ }^{43}$ Fora do Eixo es una red de colectivos culturales que tiene actuación en todo Brasil y en algunos países de América Latina. Inaugurada en 2005, inicialmente se abocó al intercambio en el campo de la música, pero se extendió con el tiempo a otras formas de expresión, como el teatro y las artes visuales. En el marco de una charla titulada "Experiencias de desarrollo de la música emergente en América del Sur", un 
A principios de agosto de 2012 nos volveríamos a encontrar muchos de los ahí presentes y otros que se sumaron en la casa de un músico de uno de los sellos de La Plata, de donde nos recogió una combi contratada por la Secretaría. Nos llevó a una ex fábrica textil, ubicada en el barrio porteño de San Telmo y recuperada como taller, espacio de encuentro y local de fiestas por un colectivo de artistas musicales y visuales. Mariano me contó que había conseguido el lugar a través de sus contactos en el mundo de la música: me dijo que "los pibes" no tuvieron problemas en prestarlo para el evento, aunque igualmente desde el programa "les tiramos unos mangos". Me planteó que el lugar era muy acorde a cómo él y su equipo -del cual se encontraban presentes dos estudiantes universitarios avanzados- pensaban que debía desarrollarse el encuentro. En este sentido, rescató que hubiera un metegol para jugar, lo que indicaba que no era un lugar acartonado o "formal", a los fines de mantener un tono relajado y de confianza entre los participantes.

Esta primera capacitación en Buenos Aires del programa se desplegó durante más de seis horas. La primera parte estuvo orientada a la explicación de la técnica del streaming ${ }^{44}$ por Santiago, socio treintañero de un emprendimiento dedicado a la transmisión de recitales en video online. La segunda, a la presentación de las personas y los colectivos presentes. A lo largo de lo que quedaba del 2012 se sucederían otras cuatro jornadas de charlas y capacitaciones, acompañadas de recitales en Tecnópolis de las bandas que para la ocasión viajaban. En esos encuentros nos encontraríamos con músicos, agentes de prensa, realizadores visuales y productores de otros pequeños sellos y colectivos musicales del país: Córdoba, Rosario, Formosa, Mar del Plata, Tucumán, Bariloche, serían de la partida. Dada su perspectiva federal, algunos participantes del programa en la zona metropolitana de Buenos Aires viajaron a capacitaciones que se realizaron en otras provincias: la idea era que de cada colectivo (a partir de "referentes" que se planteaban móviles) también pudiera aportar un "saber" y volverse un capacitador de los otros.

Dentro del espacio de las capacitaciones y reuniones del programa, en las presentaciones de los colectivos y en los intercambios entre ellos, los problemas de la gestión del propio quehacer musical, especialmente en lo que refiere a uno de los

representante de Fora do Eixo disertó en uno de los encuentros del programa que en este trabajo se presenta.

${ }^{44}$ Como explicó Santiago en la capacitación, se refiere con streaming a la reproducción de un contenido sin descarga (es decir, sin dejar de usar Internet) como sucede en sitios musicales como myspace o bandcamp. 
sentidos del "vivir de la música" (es decir, a posibilidades económicas que se ven limitadas pero no dejan de querer incrementarse) aparecían como un problema básico. En este marco, los recursos y posibilidades que pudiera habilitar el programa resultaban importantes, pero también las redes y nuevas amistades (en el sentido ya expuesto en esta tesis) que se iban generando entre los participantes, las cuales trascendían el programa que los había reunido. Las capacitaciones y los viajes financiados por la Secretaría fueron aprovechados por estos músicos para realizar "fechas" por fuera del programa, lo que redundó en una ampliación de los "contactos". Pero también las capacitaciones adquieren positividad por sí mismas: resulta claro que en ellas efectivamente se aprende algo: muchos de los saberes expuestos en las "capacitaciones" luego eran aplicados a posteriores eventos (por ejemplo, la técnica del streaming en los recitales que siguieron a la capacitación de muchas bandas de los sellos participantes).

Las capacitaciones y las experiencias habilitadas por el programa permitieron generar y/o ampliar los lazos de "amistad", lazos que, como fue sugerido, funcionan en este campo tanto a modo de articulación moral como de capital social. Estos lazos afectivos, además, se hallan en el propio éxito de convocatoria del programa. Esta dimensión vincular iría volviéndose cada vez más clara para sus propios promotores, al punto que en su presentación oficial ${ }^{45}$ se lo conceptualiza en parte como un "punto de encuentro" entre productores estéticos y un "nexo" entre los colectivos de música emergente e instituciones, entidades y empresas del ámbito público y privado. En este proceso, el programa se fue delineando como un "facilitador" y los promotores del programa, desde su inscripción en el Estado, se fueron planteando a sí mismos como "aliados" de estos músicos y de sus proyectos. La incidencia en las conversaciones de la palabra aliados era muy significativa: aliarse, ponerse de acuerdo para un fin común, implica una relación más puntual y restrictiva que la de los amigos en la que los aliados ofrecen una cooperación técnica y económica. Esta cooperación, si bien no supone la fuerte afinidad moral que implica la categoría de amistad en este campo, no por eso se resuelve en la frialdad de un aparato burocrático: apela a la mutua simpatía, basada en una concepción compartida de los problemas y de sus posibles soluciones.

En este punto, no obstante, debe puntualizarse que la traspolación a una idea de alianza no resultaría justa con la imagen que algunos músicos se hacen de la relación

\footnotetext{
45 Refiero a los documentos oficiales del programa (videos y posts en las redes sociales) y a la presentación que hizo de él la subsecretaria de Cultura de Nación, dentro del MICA realizado en Tecnópolis en abril de 2013.
} 
con el Estado, en parte porque su situación de poder es claramente disímil. La relación con Mariano y con el resto de los promotores, dada su trayectoria y una educación sentimental en parte compartida con los músicos, podía ser planteada con convicción bajo la idea de un "aliado". Sin embargo, estos aliados no dejaban de estar trabajando para el Estado, aparato del cual la tradición de la cultura rock argentina enseñó a estos músicos que no debían esperar más que mal entendimientos y censuras, que podían llegar al extremo de la represión (Vila 1985, Pujol 2007, entre otros). En este sentido, desconfianzas y sospechas sobre las que se consideran operaciones clientelares del Estado sobre la música solían (y suelen) ser formuladas, quizás de manera residual, ya que termina por prevalecer la disposición a tratar con sus agentes e instituciones. Cabe marcar que esta disposición no necesariamente va acompañada de una identificación ideológica con quienes son gobierno.

Volviendo al programa, las preocupaciones de los músicos por la gestión y la sustentabilidad de sus proyectos musicales adquieren un sentido particular en relación con el Estado y las nuevas relaciones que con él se traman. Hacer las cosas de un modo más "prolijo" o quizás más "profesional" (nuevamente, la polisemia de esta noción) es el requisito que desde el programa se les plantea a los músicos para participar de los recursos estatales. En este sentido, el espacio abierto por el programa, sus charlas y el hecho de compartir problemas enfocados en la gestión parecería constituirse para los músicos en una manera de positivizar moralmente un objetivo, el de profesionalizarse, que en otro momento (tanto de las trayectorias biográficas de muchos implicados como de la música indie e independiente) hubiera sido representado de forma negativa o ni contemplado como posibilidad. Sin embargo, desde su perspectiva, esto mismo puede conllevar una pérdida de la "identidad", un valor fundamental en la música independiente $^{46}$ (vinculado a otros como libertad, autenticidad, creatividad y originalidad), que el campo que acá presento no refiere tanto a cuestiones estéticas o políticas (si bien estas no dejan de estar involucradas) sino a un modo de producir entre amigos, con gente que comparte las "propias reglas".

Un detalle en la oficialización del programa evidencia este punto problemático. En el transcurso de las distintas capacitaciones y encuentros en los que participé, la independencia era la categoría más usada por los músicos, y también por los

\footnotetext{
${ }^{46}$ Entendida como una construcción, esta noción es resaltada como central para la música independiente por otros trabajos que en el contexto local se han dedicado a su estudio (Quiña 2012, Vecino 2011, entre otros).
} 
promotores, para referir a los sellos y las actividades que estos realizaban. Sin embargo, cuando el programa encontró su slogan eligió la categoría de emergente y no de independiente para calificar a la música que se estaba promocionando, y también, legitimando. La noción de independencia, poseedora de una carga semántica muy fuerte anclada en la tradición del rock, de selecciones específicas del rock, y vuelta un valor por el cual se disputa en ciertos mundos de la música, incluyendo el que aquí presento, no resultó del todo pertinente.

Por último, quisiera retomar aquí una pequeña polémica suscitada por este tipo de relaciones novedosas entre el Estado y ciertos músicos y sellos "independientes". A partir de la publicidad de estas iniciativas, comenzó a circular entre otros músicos que no han participado de esta relación una referencia malintencionada, la de "indie estatal". Esta expresión, levemente amplificada por el periodismo especializado y las redes sociales, pretende denunciar una situación de cooptación de los músicos por parte del Estado, olvidando que esta intervención estatal es posterior a la producción de todo aquello que sustenta las dinámicas de producción de esta música. Desde ya, la incipiente relación con el Estado reorienta estas dinámicas hacia lugares que aún no es posible determinar, pero se asienta en instancias sociales de muchos años de acumulación. En este sentido, la incorporación por estos músicos de la gestión como un momento constitutivo y prácticamente irrenunciable de su práctica musical se ha planteado de forma independiente de la posibilidad de participar o asentarse en un circuito estatalizado. Por otra parte, cabe preguntarse si esta acusación de indie estatal no se corresponde también a un momento de puja entre los músicos por la distribución misma de los subsidios y las posibilidades, sin olvidar que la presencia del recurso estatal no puede desprenderse de un proceso de revalorización de la música y las relaciones estéticas como lugar desde donde ejercer gobernanza.

Más allá de estas polémicas, como se verá con mayor profundidad en el próximo apartado, la independencia sigue funcionando en este campo como un atributo que estos músicos, sellos y demás colectivos quieren adjudicarse legítimamente a la vez que participan de programas como el descripto y de otras iniciativas estatales en la producción musical. Se asiste así a una diferencia entre concepciones de la independencia que identifican ausencia de subsidio con pureza y concepciones que reivindican la relación positiva con el Estado, apoyándose en parte en sus recursos para sostener la producción propia y no percibiendo amenazas a su producción estética por recibirlos. Claro que el Estado resulta en esta relación el detentador del mayor poder, 
tanto económico como simbólico, pero esta primera aproximación al problema apuntó más bien a sondear las posibilidades que para los músicos estudiados abre la relación con sus programas y agentes. Aquí pueden encontrarse aprovechamientos y astucias (De Certeau 2000) que son importantes cuando se trata de trayectorias desplegadas con mucho esfuerzo tanto en lo económico como en el hecho de hacerse un lugar y permanecer.

\section{Independencias}

El modo de gestión musical descripto en las páginas anteriores seguramente sea identificado por los lectores con la idea de la independencia, en circulación tanto en la bibliografía académica como en las propias escenas musicales. Un sentido social predominante refiere con esta expresión a los artistas y/o sellos que serían independientes de las grandes compañías, dada la ausencia de un contrato discográfico con algún sello major ${ }^{47}$ o propiedad de una major, aunque muchas veces dependan de ellos para la distribución (Shuker 2005, Yúdice 2008). Esta es una definición muy común que recorta un campo de gran diversidad: músicos que aún no han editado placas ni tienen relación con productoras y /o discográficas, músicos que han editado de forma casera, músicos que producen y/o distribuyen a partir de sellos como el que fue a pequeñas empresas con cierta cantidad de empleados), etc. Estas diversas relaciones con la industria discográfica son acompañadas de situaciones también muy heterogéneas respecto al uso de las tecnologías, las modalidades de profesionalización, las formas de la legalidad adoptadas, para no hablar de las estéticas disímiles que las acompañan, las retóricas más o menos politizadas, entre otras dimensiones de análisis.

Asimismo, en la mayoría de las construcciones que circulan socialmente, lo independiente tal como fue anteriormente definido -tanto en música como en otras producciones culturales- aparece contrapuesto a lo "mainstream", anglicismo usado para referir a los gustos y preferencias mayoritarias, asociadas a los grandes medios masivos. Por lo general, esta distinción implica un contraste moral, donde lo independiente es siempre creativo, puro y democrático frente a lo pretendidamente estandarizado,

\footnotetext{
${ }^{47}$ La industria de la música en cada país se divide en majors, las grandes empresas globales, y las independientes (llamadas indies o minors), que van desde las micro empresas de subsistencia y las PyMEs hasta las grandes empresas nacionales, usualmente pertenecientes a conglomerados mediáticos (Yúdice 2008). Así, las “major labels” son Universal, Sony-BMG, EMI y Warner Music, multinacionales que se han diversificado hacia otros campos del "entretenimiento".
} 
corrompido y oligárquico. Sin embargo, la oposición mainstream / independiente adquiere valencias específicas en los distintos casos empíricos. En el mundo indie, se usaba en especial para referir negativamente, no sin ironía, a los herejes dentro de un nosotros ampliado: artistas indies que se habían vuelto mainstream en sus sonidos y estéticas, si bien seguían "independientes" en su relación con la industria discográfica. Claramente, estos artistas no entraban en la definición convencional de circuito mainstream, es decir, el circuito tradicional de las grandes compañías discográficas ${ }^{48}$. Esto debería servir de advertencia al respecto de que las dos definiciones conectadas de la independencia que se presentaron, ambas socialmente predominantes, pueden volvernos insensibles a las definiciones de la independencia (y sus alterizaciones) que producen las relaciones sociales específicas que como analistas estudiamos.

Parte de la bibliografía académica en este campo de estudios construye el concepto de independencia desde los usos propios del grupo analizado, pero no da cuenta de dicho carácter "nativo" y supone cierta generalidad en los usos encontrados. Estos trabajos presentan la independencia como categoría aproblemática y suponen que es posible aislar algún valor central que la definiría. Sin embargo, dicho valor es virtual y objeto de una disputa. La independencia es un atributo que los músicos buscan y, como sucedía con la categoría indie, responde a una lucha en la que cada caso empírico realiza una ponderación concreta de diferentes valores y actitudes asociados a la independencia, combinación que se pretende, no obstante, más verdadera o auténtica que otros. Asimismo, en la mayoría de los trabajos académicos, la categoría de música independiente (o incluso más ampliamente, de la de producción cultural independiente) aparece como punto de partida para entender otras cuestiones relativas al objeto de análisis elegido. Desde nuestra perspectiva, por el contrario, el carácter independiente de la producción musical debe ser analizado como producto de múltiples determinaciones, es decir, como un punto de llegada.

Algunos avances de investigación locales (por ejemplo, Corti 2009; Quiña2009a, 2009b 2012; Mihal y Quiña 2011), sistematizan algunos rasgos caracterizadores de la condición independiente: la pequeña escala de producción; el fuerte protagonismo del vivo; el predominio de vínculos personales - presentados como cooperativos y afectivos; la creencia de que existe una correlación positiva entre la independencia, por un lado, y la integridad artística y la calidad estética, por el otro, etc. Desde mi lectura, estos

\footnotetext{
${ }^{48}$ En ese sentido usan el concepto de "mainstream" autores como Vecino (2011) y Quiña (2012).
} 
rasgos relacionan lo independiente con un régimen de trabajo más que con un régimen de circulación, construcción con la cual coincido desde el trabajo de campo. A su vez, en todas estas investigaciones puede leerse que la independencia no es un atributo exclusivamente indie. En diálogo con ellos, el caso acá presentado agrega que entre los indies se juega una noción de independencia que guarda distancias con el concepto que de ella tienen otras músicas independientes locales, tanto del presente como del pasado. Esta independencia indie no es un regodeo purista en lo under, ni tampoco se opone de manera tajante a instituciones establecidas de la industria musical como sucedía para otras "independencias" históricas del rock nacional. No es la independencia paradigmática de Los Redondos, construida alrededor de los valores de la disconformidad política, la izquierda y los sectores populares. Tampoco es la independencia del rock barrial que se ubicó como continuador de esa línea "resistente" crítica al sistema (Benedetti 2008), ni la independencia de gran parte de la música "alternativa" de los noventa, esperada transición hasta acceder a las grandes ligas.

Por su parte, Vecino (2011) en su trabajo ya mencionado sobre nuevos sellos discográficos y música independiente en la ciudad de Buenos Aires, también entiende la independencia en relación a la propia producción musical, a la vez que enfatiza ciertos componentes éticos y estéticos que dicha noción moviliza, a los que considera componiendo una ideología. El valor de lo artesanal, del riesgo, de la amistad, son enfatizados en su análisis de ciertos sellos porteños, como en el nuestro propio. Al respecto de la variable ideológica que propone su trabajo, considero que la independencia que los músicos suelen proclamar en el caso aquí analizado posee elementos ideológicos, pero es difícil entender que revista el carácter de una ideología: no se trata de un manifiesto, sino de la condición de realización de las prácticas. En ese sentido, pienso la independencia como una categoría productiva, como un marco que permite ubicar, comprender y volver coherentes desde el punto de vista de estos actores prácticas diversas.

Más específicamente, en el caso aquí presentado la noción de independencia aparece fuertemente asociada a la idea de libertad, no tanto la estética, sino la de hacer las cosas del modo en que quieren, a partir de "las propias reglas". Es interesante que la independencia enfatice en el hacer las cosas: claramente, es posible contar con libertad estética y no hacer las cosas en libertad, asimismo, hacer las cosas en libertad no implica necesariamente libertad estética. Este privilegio del hacer sobre la elección estética, que ya se tematizó al respecto del lo fi, conlleva que los componentes estéticos 
sean menos reivindicados como valores centrales de la independencia (a diferencia de otras músicas que disputan la categoría). En este marco, este "hacer las cosas en libertad" implica, al decir de Joaquín, "no ser empleado de nadie", o como expresaban los chicos de una de las bandas en una entrevista mediática, "ser tu propio jefe". Aquí vemos cómo la independencia aparece asociada también a cuestiones de honor, que ya fueron tratadas cuando se examinó el rechazo del "pagar para tocar”. En definitiva, este hacer no refiere a otra cosa que al régimen de trabajo, por ende la categoría de independencia debe entenderse en relación a otras dimensiones ya presentadas: "lo relajado" y la centralidad de los amigos.

En la práctica, la independencia así entendida permite que estas bandas participen de programas, proyectos y eventos organizados por entidades públicas (como se vio en el apartado anterior), o por compañías privadas, como los festivales Pepsi Music o Personal Fest. La independencia así entendida tampoco impide a estos músicos participar de eventos con figuras reconocidamente mainstream como Fito Páez, o aceptar participar de un video para MTV, como mecanismos legítimos de promoción. Como ellos mismos dicen, la independencia es la que hace posible decidir por sí mismos, sin que ningún contrato los obligue, si tocan acá o allá, si dicen que sí o que no. Nuevamente, como en el caso de la categoría careta, la independencia admite compatibilidades que en otros casos históricos no ha admitido: con los grandes medios, con las grandes marcas, con los gobiernos, con las instituciones estatales. De esta manera, ya no puede pensarse como pura alteridad.

Finalmente, al respecto de la relativa importancia que adquieren hoy en día las producciones musicales “independientes", es necesario referir a los posicionamientos de condena o aprobación más o menos velados en los que incurre la bibliografía sobre la condición independiente de la música. Para algunos, la independencia es una condición conquistada, a la que se le otorga por lo general un contenido estético. Estas posiciones no terminan de desprenderse de las oposiciones propias del grupo analizado (especialmente "comercial" y "artístico") y reproducen dichos valores a modo de análisis sociológico. Desde nuestra interpretación, la independencia no es una conquista (producto de la lucha y el esfuerzo que nos muestran los entrevistados), sino una condición sobredeterminada: es el resultado del modo de producción musical particular que hemos descrito y analizado en las páginas anteriores.

Para otros, la independencia no es más que un momento, una ilusión, un efecto de la situación del mercado sobre el productor de música. Para estos trabajos (por 
ejemplo, Quiña 2012), que miran nuestro objeto desde el mercado musical en su conjunto, sellos como el aquí estudiado cumplirían el papel de censores primarios de artistas que tienen la expectativa de firmar, en un futuro no muy lejano, un contrato con una gran compañía. Este tipo de razonamientos transforman la contingencia en teleología e identifican el estado más sólido que pueden alcanzar estos actores con el único punto de deseo y de llegada. En el caso aquí tratado, es probable que algunos deseen firmar con una de ellas, pero seguro que eso no es lo único que quieren: el trabajo de campo realizado hasta ahora no habilita a entender la independencia meramente como un momento ni por su significado potencial para las grandes discográficas. Es más, este trabajo habilita a pensar, por el contrario, lo que dicho sector dominante da a estas bandas. Tocar en el Pepsi Music o en el Personal Fest, como grabar presentaciones para MTV, se constituyen desde el punto de vista de estos actores como una posibilidad de contar con unas condiciones de ejecución de mucha calidad inimaginables el resto de sus días y con mecanismos de promoción que les permiten acceder a otras audiencias. Además, lo cobrado allí permite financiar presentaciones más chicas, gastos de viajes y video-clips, entre otras actividades que se hacen de forma colaborativa, como he descrito. Desde ya, ello no implica olvidar el poder material y simbólico de las industrias culturales globales frente a los actores en estudio, pero en situación ese poder puede ser usado en provecho propio. 


\section{Conclusiones}

Esta tesis se propuso analizar la singularidad de un mundo musical emergente contemporáneo, el de la denominada música indie y sus fronteras de sensibilidad, en la ciudad de La Plata, para poder pensar modos, estilos y dinámicas de producción musical que se hallan en un momento de emergencia y se sintetizan, en parte, en la configuración que he denominado sello, siguiendo la convención propia de los actores. El carácter de novedad (o no) de esta música y de sus modos de producción resulta estar en el centro de la discusión, tanto entre los músicos como en el ámbito que al interior de las ciencias sociales se dedica a su estudio. En este plan, se intentó evidenciar los límites de la bibliografía y de los abordajes teóricos más arraigados para pensar estas prácticas. Esta literatura busca una forma de realización de la música (las grandes escenas, los públicos masivos, los artistas estelares, las compañías discográficas tradicionales) que ya no direcciona ni orienta todas las prácticas posibles en ese ámbito, a la vez que actualiza una forma de la interpretación que se corresponde tanto a otras relaciones históricas entre la sociedad y la música como a momentos de la teoría que han recibido críticas consistentes, coherentes con otro modo de pensar esa relación.

Para ello, esta tesis se orientó a una unidad particular de observación: un sello que al momento de realizar el trabajo empírico y aún en la actualidad aparece asociado al indie local. Asimismo, se complementó esta mirada con las observaciones de un trabajo de campo etnográfico en curso con otros sellos independientes y emergentes de la misma ciudad y de la zona metropolitana de Buenos Aires. De esta manera, se pudo analizar el surgimiento de un tipo de organización social alrededor de la música que, a pesar de su nombre conocido, remite a una realidad diferente a la que construyó tradicionalmente el mercado y la industria discográfica. En este sentido, la abreviación usual por parte de los músicos de la idea de "sello discográfico" en la de sello, resultó una primera pista de cómo sus actividades han dejado de responder de forma única a un patrón de edición de discos, e incluso a un patrón exclusivamente musical. En la descripción y análisis del mundo estético que un sello particular (Tigra) articula, el objetivo fue también evidenciar las dinámicas sociales que produce una generación, la mía propia, pensada como productora de acción y de relación social en la música.

Para empezar, se interpretó lo indie en su diferencia con lo independiente tal como es tratado en el campo. Lejos de considerar lo independiente como unas muy generales condiciones técnicas a la hora de hacer música, se consideró que la condición 
independiente de la música recorta en el mundo construido como rock un valor por el cual se apuesta, mientras que en ese juego el indie apela a su vez a un estilo que recibe significaciones diferentes. De acuerdo a la construcción analítica presentada, en La Plata dicho estilo aparece configurado por un "ser relajado", un "ser rockero" y un no "ser careta". Lo relajado, como una forma de relacionarse con la música y de producirla que se entiende en el marco de una situación ecológica particular y como respuesta a unas condiciones restrictivas y conecta en el análisis con el minimalismo de la ambición característico de estas bandas. Lo rockero porque, a diferencia de otros mundos indies recuperados por la literatura, el que aquí trato se construye a partir de una prolongación de ciertas actitudes de transgresión atribuidas a la cultura del rock. Esto lo coloca en una disputa por el sentido del rock nacional, diferenciándolos de quienes, identificados también como indies, consideran intrascendente esa batalla. La acusada impronta anticareta, por su parte, viene a resignificar una noción históricamente presente en las diferentes culturas juveniles, y en particular, en los mundos del rock. Sin embargo, lo careta ya no se identifica tanto con "lo comercial", sino con el carácter contracturado y ambicioso, dada la mayor legitimidad que conquista la noción de mercado y su familia semántica en este mundo musical. A partir de la descripción y análisis de estas categorías en Tigra, un sello particular de la escena, intenté mostrar una forma en la que se produce la pertenencia simbólica a un mundo musical, la producción de sentidos y de afectividades que acompañan y también constituyen a una organización social alrededor de la música.

Es importante notar que en la lógica de los géneros musicales, reproducida por las publicaciones "jóvenes" especializadas pero también por algunos trabajos académicos, el indie aparece como una música con ciertos rasgos característicos que se asocia a las clases medias y se ubica en una generación posterior a los años 90 . Si bien esta interpretación es posible, y tiene un momento de validez, resulta imposible acotar el indie a una pauta de género musical, ya que lo que se reivindica como indie resulta estilísticamente muy distinto en cada caso, como se ha mostrado a partir de la configuración singular de esta música en La Plata. Más aún, el indie en sí mismo ya resulta, incluso cuando es reivindicado como género, una música trans-genérica, que quiere desbordar los géneros musicales hasta volverlos irreconocibles. Los criterios de la mezcla entendida como la puesta en compatibilización de lo antes incompatible regulan la producción del indie, inscribiéndolo en un proceso más general documentado por desarrollos de investigación muy recientes que describen cómo se han fragmentado 
y particularizado las pautas de adhesión a los géneros musicales, especialmente entre los jóvenes pero no sólo entre ellos (Ochoa 2003, Vila y Semán 2008, Gallo y Semán 2013). En este sentido, he intentado mostrar que la especificidad de las formas de relación con la música, de sus usos (en una noción ampliada de este concepto), debe integrarse a la descripción y análisis de lo que todavía se reivindica a partir de un estilo. Acerca de ello, he intentado demostrar que para el caso del indie producido en La Plata para un período contemporáneo la música resultante no puede comprenderse sin un análisis del sello, la institución mediadora desde la cual estos músicos pueden habilitar específicos cursos de acción y de relación social en la música.

En particular en lo que refiere al sello, partí de mi sentido común social y sociológico sobre sus características para descubrir a partir del trabajo de campo la reformulación que estos mundos musicales operan en él, a la vez que su centralidad e importancia, a tal punto que la mirada de la etnografía se deslizó hacia él, cuando se había posado en un primer momento sobre las bandas. Esto es: en un primer momento, de acuerdo al recorrido etnográfico que había realizado, concebido a partir de la idea de escena, el sello apareció para mí como una forma de dar inteligibilidad a las interacciones que ocurrían hacia su interior: "los Uf Caruf”, "los Concepto Cero", "los chicos de Dice Discos" aparecían como formas de referenciar personas, proyectos musicales, modos de trabajo y, entendidos de una manera muy amplia, estilos. En este sentido, la idea de sello como un "sellito" que se imprime a los discos resulta demostrativa de este tipo de conceptualización (tanto "nativa" como propia). Luego, la orientación de "seguir a los actores", y el propio devenir entre los años 2009 y 2012 de los sellos como instituciones que amplían su rango de acción y su influencia en la música emergente, me hicieron otorgarle un privilegio a un sello. Me encontré de esa manera con una construcción mucho más densa que lo que la categoría de inteligibilidad (y su fuerte dejo cognitivista) permite referenciar. El desplazamiento del análisis hacia el sello, entonces, resulta de un doble tránsito: de los propios sellos en la música emergente y de mi persona por este mundo de prácticas, reelaborando el objeto en ese trayecto.

A partir de este recorrido, se ha construido una noción de sello como un punto de conexión entre las dimensiones identitarias y afectivas, las musicales y, por último, las referidas a lo que se asume como gestión e incluye, desbordándolo, a lo estrictamente económico. En primer lugar, entonces, los sellos permiten articular sentidos de pertenencia permeados por distintos grados de afectividad, a partir de los 
cuales se delimitan quienes hacen tal música o tal otra, quiénes ostentan determinado estilo u otro, definiciones que no están subordinadas al criterio de género musical. Mostré cómo se produce una diferencia en un contexto de sobreoferta musical, incluso cuando quienes los llevan adelante niegan o relativizan adscripciones identitarias en un sentido clásico (a partir de determinados rasgos estilísticos o específicamente de género musical). En este sentido, resulta interesante enfatizar las dimensiones de la agencia que se habilitan a partir de la figura del sello, en este contexto de particularización de la producción musical por efecto de los usos de las nuevas tecnologías. Esta situación alerta al menos dos cuestiones. Primero, la exigencia que traen las transformaciones contemporáneas de pensar las identificaciones a escalas mucho más pequeñas que las que suponen las comunidades interpretativas construidas en la mayoría de los estudios de música popular en el contexto local, como se ha visto en la Parte 1. Segundo, como seguiré desarrollando más adelante, la necesidad de evidenciar la positividad y la eficacia de aquello que generalmente se encuentra subestimado u ocluido en los análisis: el afecto en la producción de música.

En segundo lugar, el sello refiere a las redes en las cuales se producen formas específicas de apreciación, evaluación y legitimación de la música. En la selección de las más variadas músicas, en el desarrollo de técnicas de escucha, en la construcción de una tradición de antecesores y de ídolos - muchas veces músicos accesibles que pueden volverse amigos-, en la manipulación de músicas y sonidos producidos por otros, en la propia práctica con el instrumento y con dispositivos de producción musical, los grupos de amigos construyen, como ha planteado Hennion para otro contexto (2012: 226), su propia sociología del gusto. En el caso del indie analizado en La Plata, la inclinación por lo relajado y por el lo fi (como se describió, técnicamente una grabación de baja fidelidad que amplía su sentido hacia un enfoque estético en la producción musical), encuentra una legitimidad propia que, sin dejar de alterizar con ellos, no tiene sin embargo necesidad de responder a los cánones dominantes de lo "virtuoso" y del "buen sonido".

En tercer lugar, el sello es un dispositivo de producción y gestión de los proyectos y obras musicales, donde se incluye la dimensión de la obtención de ganancia y de la sustentabilidad económica de las prácticas estéticas. Sin embargo, como se vio, no es mera empresa racionalizada y organización altamente estructurada ni tampoco algo que intenta emular, sin éxito, dichos modelos. Como institución en los mundos musicales emergentes, el sello abarca las distintas instancias que son divididas 
tradicionalmente como producción, distribución y consumo. Mirado bajo este aspecto, el sello es un "grupo de amigos que hace cosas" que funciona no meramente como rúbrica, sino como núcleo de aprendizaje en la gestión de la propia práctica musical, activador de un mercado (básicamente local y de la zona metropolitana), recurso de comunicación y distinción, conector con redes más amplias de producción cultural. En el análisis de la forma sello interesó trascender el economicismo implícito que ve en la música sólo una forma más de la mercancía. Desde ya: la música producida se constituye en una mercancía pero considerar este carácter como determinante de todas las dimensiones de un fenómeno complejo, donde se incluyen moralidades en la relación con la música, formas de gestión, modos de producción, relaciones con el trabajo, construcción de afectividad, resulta empobrecedor y reduccionista, más aún, cuando esas dimensiones se encuentran vinculadas a una reconfiguración de los mercados musicales y de las condiciones de mercantilización de los productos en la música (Yúdice 2002 2008, Fouce 2010, entre otros).

El desplazamiento del análisis, entonces, permitió entender la complejidad de un mundo del arte dinámico, donde no son específicamente las bandas y/o los solistas las que lo articulan. En este sentido, este desplazamiento es también un pasaje a nivel de la producción sociomusical, pasaje que encuentro en proceso de generalización en la continuidad de mi trabajo de campo con sellos de la zona metropolitana. Estos sellos complejizan su significación en la estructura de la música para dinamizar ciertas redes de sociabilidad "joven": organizan fiestas, ciclos de recitales, festivales, veladas de lectura, etc. Su carácter de emprendimiento discográfico es importante pero mucho más lo es su carácter de red social que sobredetermina la producción y el consumo de la música. En otras palabras, los resultados permiten presentar al sello como la institución mediadora fundamental para la música emergente contemporánea que disputa lo “juvenil” al interior de las clases medias de la zona metropolitana de Buenos Aires.

Las redes de cooperación del mundo musical presentado, pero también las de otros mundos musicales afines, tal como indica la bibliografía argentina (pero también la mexicana o la española), producen música y otros productos artísticos relacionados a partir de interacciones y relaciones moduladas por la narrativa de la "amistad", sin la que la música resultante sería completamente otra. En esta tesis aposté a la desnaturalización de esta noción para comprenderla en su operatividad en el mundo musical en estudio, cuya vinculación estrecha con ciertos sectores de la vida universitaria (especialmente aquellos donde las disputas estéticas son importantes) es un 
dato desde el cual partir. A lo largo del texto, he querido desplegar los sentidos locales y situados de esta categoría, no circunscripta a una noción de intimidad emocional, para entenderla al menos bajo dos sentidos. En el primero la amistad debe vincularse a las redes, conexiones y contactos, como parte de la organización de la práctica de hacer música. En este sentido, los amigos se guardan cierta reciprocidad en lo que cada uno realiza para que el otro pueda llevar adelante sus proyectos musicales. Entonces, y en un segundo sentido vinculado, en este hacer música en conjunto, los amigos comparten de alguna manera "las propias reglas" del trabajo artístico. Es decir, los amigos se saben afines en una manera específica de ser músicos, de ser artistas, una forma en la que se vive espiritualmente de la música. En contextos signados por la fragilidad y la incertidumbre, estas prácticas y sentidos, la amistad como narrativa y como práctica, asume un papel en el despliegue y el sostén de los proyectos musicales.

En relación a este último punto, entiendo que la amistad se constituye en una fuerza operantes en la construcción de instituciones musicales como el sello. Quisiera resaltar el valor y la eficacia de estas construcciones afectivas puesto que son comúnmente ignoradas en una sociología distribucional de la distinción. En el caso que aquí presenté, la amistad como tipo de lazo característico, en su peculiaridad de no exigir intimidad pero sí cierta reciprocidad, se corresponde al modo de producción: un modo que envuelve a los músicos y a los públicos en la co-constitución musical. De esta manera, en esta instancia de producción de música la pregunta por la amistad es también una pregunta por lo que la literatura figura como prosumidores. Músicos que son fans de otros músicos, bandas que son el público y el sostén de otras bandas de su propio sello o de sellos amigos, diseñadores, fotógrafos y demás productores estéticos que trabajan pero también consumen la música que les gusta, "públicos" que producen videos, fotos, textos y otros materiales a partir de sus canciones y bandas favoritas. Así, en este contexto "prosumidor" se redefine la propia producción en sus diferentes instancias, tanto al respecto de los modos de trabajo como en cuanto a la definición de qué cosa es producto y quiénes son los amigos que producen música en conjunto. En otras palabras, la novedad de los prosumidores altera no solamente la categoría de los bienes musicales y estéticos sino también las relaciones entre las personas que consumen/ producen esos bienes. Finalmente, la perspectiva de la bibliografía sobre prosumidores debe llamar la atención al respecto de qué manera la comprensión de la figura del sello es indiscernible tanto de la producción como del consumo de música, 
afectando y regulando ambos procesos, ya que en este caso la forma en que se produce afecta cómo se consume.

Este universo de prácticas de producción emergentes le otorga centralidad a la gestión de la propia música: la gestión es un común denominador para la totalidad de estas músicas emergentes con la que he tenido contacto, volviéndose a su vez visible y ponderada en los discursos. En este mundo, la gestión, es decir hacerse cargo de las relaciones con el mercado y con el muy reciente involucramiento del Estado, implica tanto poder mantener "las propias reglas" en el trabajo artístico (lo cual supone mucho más que libertad estética: se trata de cierta autonomía en los modos de trabajo) como mejorar y controlar las limitadas posibilidades económicas. Con respecto al mercado, analicé cómo esta categoría y sus nociones asociadas adquieren una mayor legitimidad en este campo. En cuanto a la aparición de la esfera estatal, realicé una aproximación exploratoria al carácter de una política que inscribe en el Estado esta situación emergente. A partir de una serie de participaciones etnográficas en un programa estatal, marqué las oportunidades y también los problemas que se abren para los músicos participantes. Todo ello para unos proyectos musicales que se plantean de manera complementaria al trabajo fuera de la música o al estudio, revelando los contornos de un momento en el cual la clásica distinción entre los alguna vez llamados "hobbies" y las obligaciones comienza a perder rigidez. Los ingresos, por su parte, suelen permitir que las actividades que aquí se han estudiado resulten al menos auto-sustentables. Esta situación permite que el sello que conforman pueda funcionar con un fuerte dinamismo y unos rendimientos económicos que para otros resultarían desfasados del esfuerzo y completamente irrisorios.

La consagración no se entiende necesariamente en términos mediáticos o de estrellato masivo (si bien la referencia o la aparición en los medios tradicionales es vista como un triunfo y un reconocimiento), sino en "hacer lo que se quiere", es decir, realizar un camino acumulativo que permita "no pagar para tocar", ganar cierto dinero que pueda cubrir los gastos de la presentación y/o reinvertir en la banda (en el contexto de complementación de actividades ya mencionado) como también obtener evaluaciones positivas hacia el interior de una escena de pares. Los músicos con los que traté son plenamente conscientes de estas nuevas pautas que por el momento de les presentan, las que resultan de una convergencia entre el cambio tecnológico y la reconfiguración en las condiciones de mercantilización de los productos musicales. En este sentido, me propuse documentar la "lógica cambiada" en la que estos músicos se 
mueven, una situación en la que, como me decía uno de ellos, "si hoy estuviésemos en los noventa, [una banda consagrada dentro de la escena] ya sería como Attaque 77, ponele. Una banda así. Porque en esa época el mercado estaba re concentrado, entonces había "la banda que despegaba" (...) y el resto ahí abajo."

Para otro momento de la música juvenil en Argentina, Díaz (2005: 44) ha marcado los intentos del rock nacional para desafiar esa estructura concentrada, a partir de la creación de sellos independientes. Mandioca y Talent -dos sellos emblemáticos de esta tradición- fueron instituciones que nacieron "dentro del rock": ambos, no obstante, si bien jugaron un rol muy relevante desde un punto de vista creativo, no tuvieron un gran desarrollo económico y finalmente fracasaron. Su papel fue más bien el de promocionar nuevos talentos que luego eran contratados por las compañías más grandes (Díaz 2005: 47). Algunos trabajos recientes en el campo de estudios local afirman que actualmente esa configuración se mantiene. Frente a la centralidad que hoy en día ha adquirido la música independiente, estos planteos afirman hay que ir más allá de la apariencia que separa la música independiente (lo que aquí he elegido llamar emergente) y su contraparte en el "mainstream", dado que esta oposición no sería más que una teoría propia de los actores involucrados, donde se distinguen lógicas fundadas en el interés y el mercado frente a aquello que siempre se le ha opuesto: el desinterés, la pasión, el auténtico amor por la música. En realidad, de acuerdo a estas interpretaciones, estas lógicas están integradas, desde que la primera se ha consagrado como el motor de innovación musical de la segunda y en tanto que tienen estrategias comerciales complementarias. En contraste, en esta tesis he querido mostrar un proceso significativo para un amplio sector de la música que reivindica la categoría de independencia, donde esa manera de pensar las relaciones entre la gran industria y las llamadas "indies" ha dejado en gran parte de ser operativa y debe, al menos, complejizarse.

Más ampliamente, mi objetivo fue comprender el significado y el lugar novedoso, para nada cristalizado ni estático, que asumen estas relaciones en la música y, en particular, en la producción de música. En una interpretación de este fenómeno, Quiña (2012: 262) critica lo que se escondería tras el rótulo novedoso de "emprendedor" de la cultura y, por extensión, en la música. Con esta noción se intentaría connotar un fenómeno diferente a los ya conocidos, cuando en realidad se trata de las viejas y siempre actualizadas relaciones de explotación, junto a "una transferencia histórica de riesgo y responsabilidades en el trabajo musical desde los grandes capitales de las multinacionales al conjunto de la clase trabajadora". Por mi 
parte, a partir de un trabajo de campo prolongado que apuntó a la descripción bajo la forma de una red de relaciones, elaboré no sólo una construcción empírica sino nuevos parámetros analíticos para pensar estos datos.

De esta manera, para el análisis de los músicos emergentes y sus sellos propuse dos criterios mutuamente recíprocos de interpretación de las relaciones: la creación de organización social alrededor de la música y los cursos de acción habilitados tecnológicamente y por esa organización. En otras palabras, intenté comprender un modo específico en el cual formas de agencia y sistemas objetivos de habilitación confluyen para producir un nuevo espacio de socialización y sociabilidad. Es a este estado histórico de cosas, un estado de apertura y de emergencia, que el sello como institución clave se corresponde. En este movimiento, no intento negar ni esconder yo también la precariedad y fragilidad en la que se inscriben estas prácticas musicales. Sí marcar que por más que esas condiciones sean actualmente efectivas, y por más que incluso en el futuro empeoren, quienes las sufren también han introducido, por la propia eficacia de su agencia, novedades fundamentales en la producción musical que difícilmente puedan ser ignoradas, las cuales se inscriben en una pluralización de la producción musical, de las relaciones sociales que ella habilita, de las categorías que se utilizan para evaluarla y de las posibilidades de trabajo y de carrera en la música. 


\section{Bibliografía citada}

*Adorno, Theodor y Horkheimer, Max (1997), Dialéctica del iluminismo. México D.F.: Sudamericana.

*Alabarces, Pablo (1993), Entre Gatos y Violadores: el rock nacional en la cultura argentina, Colihue, Buenos Aires.

_, Salerno, Daniel, Silba, Malvina y Spataro, Carolina (2008), "Música popular y resistencia: los significados del rock y la cumbia", en Alabarces, Pablo y Rodríguez, María Graciela (comps.), Resistencias y Mediaciones. Estudios sobre cultura popular, Buenos Aires, Paidós.

*Alonso, Luis Enrique (1998), La mirada cualitativa en sociología, Madrid: Fundamentos.

*Auyero, Javier (1992), "Juventud popular urbana y nuevo clima cultural. Una aproximación”, en Nueva Sociedad, no. 117, enero / febrero 1992, pp. 131-145.

*Becker, Howard (2008), Los mundos del arte. Sociología del trabajo artístico, Buenos Aires, Universidad Nacional de Quilmes Editorial.

_ (2009), "La cultura en un grupo desviado de la norma: el músico de baile" y "La carrera en un grupo ocupacional desviado: el músico de baile", en: Outsiders. Hacia una sociología de la desviación. Buenos Aires, Siglo XXI

*Benedetti, María Cecilia (2008), "El rock de los desangelados. Música, sectores populares y procesos de consumo" en Revista Transcultural de Música no. 12. http://www.sibetrans.com/trans/trans12/art02.htm

*Benzecry, Claudio (2012), El fanático de la ópera. Etnografía de una obsesión. Siglo XXI Editores: Buenos Aires.

*Blázquez, Gustavo (2008), "Nosotros, Vosotros y Ellos. Las poéticas de las masculinidades heterosexuales entre jóvenes cordobeses", en: Revista Transcultural de Música no. 12. http://www.sibetrans.com/trans/a91/nosotros-vosotros-y-ellos-laspoeticas-de-las-masculinidades-heterosexuales-entre-jovenes-cordobeses

_ (2009), Músicos, mujeres y algo para tomar. El mundo de los cuartetos de Córdoba, Ciudad de Córdoba, Ediciones Recovecos.

_ (2011): Entrevista realizada por Pablo Semán, en: Revista Argentina de Estudios de Juventud, vol. 1, número 4, UNLP, La Plata:

http://perio.unlp.edu.ar/ojs/index.php/revistadejuventud/article/viewArticle/1499 
*Boix, Ornela (2011), “'Yo toco la guitarra como soy’: una aproximación etnográfica a la escena indie platense". Tesina de Licenciatura en Sociología, Facultad de Humanidades y Ciencias de la Educación, UNLP.

*Bourdieu, Pierre (1983), Campo de poder y campo intelectual, Buenos aires: Folios.

_ (1998), La distinción. Criterio y bases sociales del gusto. Madrid: Taurus.

_ (2000 [1982]) "La disolución del campo religioso" en Cosas Dichas. Barcelona: Gedisa.

_ (2006 [1971]) "Génesis y Estructura del campo religioso" en Revista Relaciones, n. 108. Otoño 2006, Vol. XXVII.

_ (2010), El sentido social del gusto. Elementos para una sociología de la cultura. Buenos Aires, Siglo XXI.

*Brubaker, Roger y Cooper, Frederick (2001), "Más allá de identidad" en: Apuntes de investigación del CECYP, no. 7, Abril, Buenos Aires.

*Carnicer, Lucio (2008), “La U.M.I. Música, industria e ideología”. Trabajo presentado en VIII Congreso IASPM-AL. Pontificia Universidad Católica del Perú. Lima, 18 al 22 de junio de 2008.

*Carozzi, María Julia (2009), "Una ignorancia sagrada: aprendiendo a no saber bailar tango en Buenos Aires", en: Religião e Sociedade, Rio de Janeiro, 29(1): 126-145, 2009 .

_ (2011), "Ni tan pasionales ni tan decentes: tras las huellas de la liviandad en las clase de tango milonguero y las milongas céntricas porteñas", en: Las palabras y los pasos. Enografías de la danza en la ciudad. Buenos Aires: Gorla.

*Cingolani, Josefina (2013), “Rock post-Cromañón. La reconfiguración del circuito de rock platense”. I Jornadas Interdisciplinarias de Jóvenes Investigadores en Ciencias Sociales. IDAES, Universidad Nacional de San Martín. 8, 9 y 10 de mayo de 2013. San Martín, Buenos Aires, Argentina.

*Citro, Silvia (2008), "El Rock como un ritual adolescente. Trasgresión y realismo grotesco en los recitales de Bersuit”, Revista Transcultural de Música ํㅜ 12

http://www.sibetrans.com/trans/a88/el-rock-como-un-ritual-adolescente-trasgresion-y$\underline{\text { realismo-grotesco-en-los-recitales-de-bersuit }}$

*Clarke, John; Hall, Stuart; Jefferson, Tony y Roberts, Brian (2010): "Subculturas, culturas y clase" en: Resistencia a través de rituales. Subculturas juveniles en la Gran Bretaña de posguerra. La Plata: Observatorio de Jóvenes. Comunicación y Cultura, Facultad de Periodismo y Comunicación Social, Universidad Nacional de La Plata. 
*Collado, Pablo (2010), “Cruces entre la cultura de masas y la radicalización política en el giro contracultural del rock argentino". Tesis de Licenciatura en Historia. Facultad de Humanidades y Ciencias de la Educación, UNLP.

*Corti, Berenice (2007), "Las redes del disco independiente: apuntes sobre producción, circulación y consumo", en VV.AA., Las Industrias Culturales en la Ciudad de Buenos Aires, Concurso de Ensayos 2007, Trabajos Premiados. Observatorio de Industrias Culturales de la Ciudad de Buenos Aires, Gobierno de la Ciudad de Buenos Aires. _ (2009), "Redefiniciones culturales en la Buenos Aires post Cromañón. El debate sobre el vivo de la música independiente". Ponencia presentada en VIII Reunión de Antropología del Mercosur, Buenos Aires. 29 de septiembre al 3 de octubre de 2009.

*Cragnolini, Alejandra (2006): “Articulaciones entre violencia social, significante sonoro y subjetividad: la cumbia 'villera' en Buenos Aires”, en Revista Transcultural de Música, n. ${ }^{\circ} 10$. http://www.sibetrans.com/trans/trans10/cragnolini.htm

*Dale, Pete (2009), It was easy, it was cheap, so what?: Reconsidering the DIY principle of punk and indie music. Popular Music History, North America, 3, jul. 2009.

*De Certeau, Michel (2000), La invención de lo cotidiano I. Artes de hacer, Universidad Iberoamericana, México D.F

*De Singly, François (2006), "La sociología, forma particular de conciencia", en: Lahire, Bernard (2006), ¿Para qué sirve la sociología? Buenos Aires: Siglo XXI.

*De Nora, Tia (2000) Music in everyday life. New York: Cambridge University Press. - (2012) "La música en acción: constitución del género en la escena concertística de Viena, 1790-1810”. En Benzecry, Claudio (2012) Hacia una sociología cultural. Buenos Aires: Universidad Nacional de Quilmes.

*Díaz, Claudio (2005), Libro de viajes y extravíos: un recorrido por el rock argentino (1965-1985), Unquillo, Narvaja Editor.

*Doeswijk, Maite y Ruiz, Franco Darío (2007), El rock platense de los años 90, Tesis de Producción, Facultad de Periodismo y Comunicación Social, UNLP.

*Elbaum, Jorge (1994): “Los bailanteros. La fiesta urbana de la cultura popular" en Margulis, Mario et. al.: La cultura de la noche. La vida nocturna de los jóvenes en Buenos Aires. Buenos Aires, Espasa Hoy.

*Faulkner, Robert y Becker, Howard (2011). El jazz en acción. La dinámica de los músicos sobre el escenario, Siglo XXI: Buenos Aires. 
*Fouce, Héctor (2010). "De la crisis del mercado discográfico a las nuevas prácticas de escucha" en Comunicar: Revista científica iberoamericana de comunicación y educación, (34), 65-72.

_ (2012): "Entusiastas, enérgicos y conectados en el mundo musical" en: García Canclini, Néstor; Urteaga Castro Pozo, Maritza y Cruces, Francisco (coords.), Jóvenes, culturas urbanas y redes digitales, Madrid, Ariel y Fundación Telefónica.

*Frith, Simon (2003): "Música e identidad” en Hall Stuart y Du Gay, Paul (comps.) Cuestiones de identidad cultural. Buenos Aires, Amorrortu.

*Gallo, Guadalupe (2011), "In Coco We Trust. Club, casa y proyecto: experiencias y producción musical electrónica en un local de Buenos Aires", Tesis de maestría, FLACSO, Buenos Aires, Argentina.

_ (2011b), "Poder bailar lo que me pinta: movimientos libres, posibles y observados en pistas de baile electrónicas”, en Carozzi (comp.), Las palabras y los pasos, Editorial Gorla, Ediciones de Periodismo y Comunicación.

_ y Semán, Pablo (2009), "Superficies de placer: Sexo, religión y música electrónica en los pliegues de la transición 1990-2010”, en: Cuestiones de Sociología, Departamento de Sociología, Universidad Nacional de La Plata.

_ (2013), Introducción en: Gallo, Guadalupe y Semán, Pablo (comps.) Mezclar, gestionar, relajar. Modos de vida y escenas musicales, Buenos Aires, Gorla-EPC (en prensa).

*Gallo, Guadalupe; Garriga Zucal, José; Semán, Pablo y Spataro, Carolina (2011): "Editorial" en Revista Argentina de Estudios de Juventud, Número 4 - Juventud y música en http://www.perio.unlp.edu.ar/revistadejuventud/

*García Canclini, Néstor (2004). Diferentes, Desiguales y Desconectados. Mapas de la Interculturalidad. Gedisa. Barcelona.

_ (2012), "De la carrera a los proyectos" en García Canclini, Néstor, Urteaga Castro Pozo, Maritza y Cruces, Francisco (coords.) (2012), Jóvenes, culturas urbanas y redes digitales, Madrid, Ariel y Fundación Telefónica.

_ y Cruces, Francisco (2012), “Conversación a modo de prólogo” en García Canclini, Néstor, Urteaga Castro Pozo, Maritza y Cruces, Francisco (coords.) (2012), Jóvenes, culturas urbanas y redes digitales, Madrid, Ariel y Fundación Telefónica.

*Garriga Zucal, José (2008), "Ni “chetos", ni "negros": roqueros", en Trans Revista Cultural de Música no. 12. http://www.sibetrans.com/trans/trans12/art04.htm 
_ y Salerno, Daniel (2008): "Estadios, hinchas y rockeros. Variaciones sobre el aguante" en Alabarces, Pablo y Rodríguez, María Graciela (comps.), Resistencias y Mediaciones. Estudios sobre cultura popular, Buenos Aires, Paidós.

*Gerber Bicecci, Verónica y Pinochet Cobos, Carla (2012), “La era de la colaboración. Mapa abreviado de nuevas estrategias artísticas" en: García Canclini, Néstor; Urteaga Castro Pozo, Maritza y Cruces, Francisco (coords.), Jóvenes, culturas urbanas y redes digitales, Madrid, Ariel y Fundación Telefónica.

*Grignon, Claude y Passeron, Jean-Claude (1991), Lo culto y lo popular. Miserabilismo y populismo en sociología y literatura, Nueva Visión, Buenos Aires.

*Guber, Rosana (2011), La etnografía: método, campo y reflexividad, Buenos Aires, Siglo XXI.

*Hall, Stuart y Jefferson, Tony (2010), “Una vez más: Resistencia a través de rituales" en: Hall, Stuart y Jefferson, Tony (2010), Resistencia a través de rituales. Subculturas juveniles en la Gran Bretaña de posguerra. La Plata: Observatorio de Jóvenes. Comunicación y Cultura, Facultad de Periodismo y Comunicación Social, Universidad Nacional de La Plata.

*Hebdige, Dick (2002), Subcultura. El significado del estilo. Barcelona: Paidós.

*Hennion, Antoine (2002) La pasión musical. Barcelona: Paidós.

- (2012) “Melómanos: el gusto como performance”. En Benzecry, Claudio (2012) Hacia una sociología cultural. Buenos Aires: Universidad Nacional de Quilmes.

*Hesmondhalgh, David (1999). "Indie: The Institutional Politics and Aesthetics of a Popular Music Genre", Cultural Studies, 13 (1), 34-61.

*Hibbet, Ryan (2005). What Is Indie Rock? Popular Music and Society, 28 (1), 55-77.

*Irisarri, Victoria (2010), "Ilegalidad musical y profesión emergente". Ponencia presentada en 27 . Reunião Brasileira de Antropologia, Belém, Pará, Brasil, 1 al 4 de agosto de 2010.

_ (2011), "'Por Amor al Baile’. Música, tecnologías digitales y modos de profesionalización en un grupo de DJs-productores de Buenos Aires". Tesis de Maestría en Antropología Social. IDES-UNSAM.

*Lamacchia, María Claudia (2012): Otro cantar. La música independiente en Argentina, Buenos Aires, Unísono Ediciones.

*Latour, Bruno (2008), Reensamblar lo social: una introducción a la teoría del actor red. Manantial, Buenos Aires. 
*López Cano, Rubén (2011), "Juicios de valor y trabajo estético en el estudio de las músicas populares urbanas de América Latina”, en: Sans, Juan Francisco y López Cano, Rubén (coords.): Música popular y juicios de valor: una reflexión desde América Latina. Caracas: Centro de Estudios Latinoamericanos Rómulo Gallego.

*López, Matías David (2013). "Producción cultural, “elites culturales" y espacios de exhibición. Una aproximación a las experiencias en la ciudad de La Plata”. I Jornadas Interdisciplinarias de Jóvenes Investigadores en Ciencias Sociales. IDAES, Universidad Nacional de San Martín. 8, 9 y 10 de mayo de 2013. San Martín, Buenos Aires, Argentina.

*Luchetti, Karina (2007), "Estructuración de la producción y organización empresaria en la industria fonográfica. El surgimiento de asociaciones de productores fonográficos 'independientes"”. Tesina de grado. Carrera de Ciencias de la Comunicación, Facultad de Ciencias Sociales, Universidad de Buenos Aires. (http://comunicacion.fsoc.uba.ar/tesinas_publicadas/1829.pdf)

*Madoery, Diego (2000), "Los procedimientos de producción musical en música popular”, Revista del Instituto Superior de Música de la Universidad Nacional del Litoral, no. 7.

*Martín Barbero, Jesús (2009), Cuando la tecnología deja de ser una ayuda didáctica para convertirse en mediación cultural, en: Teoría de la Educación: Educación y Cultura en la Sociedad de la Información, Vol.10, México.

*Martín, Eloísa (2008): "La cumbia villera y el fin de la cultura del trabajo en la Argentina de los 90”, en Revista Transcultural de Música, n. ' 12. http://www.sibetrans.com/trans/trans12/art05.htm

*Miguel, Paula (2012): "La pregunta por la creatividad. Notas sobre el análisis de la producción reciente en las industrias creativas argentinas" en: Cuadernos de Filosofía Latinoamericana, Vol. 33, No. 106, pp. 113-129.

*Míguez, Daniel (2006), "Estilos musicales y estamentos sociales. Cumbia, villa y transgresión en la periferia de Buenos Aires”, en MÍGUEZ, Daniel y SEMÁN, Pablo, (eds.), Entre santos, cumbias y piquetes: las culturas populares en la Argentina reciente, Buenos Aires, Biblos.

*Moreira, María Verónica (2006): "Una mujer en campo masculino y la identificación de género en el proceso de producción del conocimiento antropológico". Ponencia presentada ante VII Seminario Internacional Haciendo Género, Florianópolis, Brasil. 
*Nardacchione Gabriel (2011), El conocimiento científico y el saber práctico en la sociología pragmática francesa. Reflexiones sobre la sociología de la ciencia de Bruno Latour y la sociología política de Luc Boltanski, en: Apuntes de Investigación del CECYP, Año XIV, No 19/ enero - junio 2011, pp. 171-182.

*Negus, Keith. 2005. Los géneros musicales y la cultura de las multinacionales. Buenos Aires: Paidós

*Newman, Michael Z. (2009). Indie culture: In pursuit of the authentic autonomous alternative. Cinema Journal 48 (3), 16-34.

*Novoa, Laura (2010), “Aproximación a una 'musicología de la producción' para el análisis de la música popular" en GARCÍA, Miguel A. (ed.), Rock en papel: bibliografía crítica de la producción académica sobre rock en la Argentina, La Plata, Edulp.

*Oakes, Kaya (2009), Slanted and Enchanted: The Evolution of Indie Culture, Holt Paperbacks.

*Ochoa, Ana María (2002), "El desplazamiento de los discursos de autenticidad: Una mirada desde la música" en Revista Transcultural de Música no. 6. www.sibetrans.com/trans/trans6/ochoa.htm

_ (2003), Músicas locales en tiempos de globalización, Buenos Aires, Norma.

*Ortner, Sherry (1999), “Thick Resistance: Death and the Cultural Construction of Agency in Himalayan Mountaineering", en: Ortner, S. (ed.), The fate of "Culture": Clifford Geertz and beyond. Berkeley/Los Angeles: University of California Press.

_ (2005), “Geertz, subjetividad y conciencia posmoderna", en: Etnografías contemporáneas. No 1. Buenos Aires: UNSAM.

*Palmeiro, César (2005), La Industria Del Disco. Economía de las PyMEs de la Industria discográfica en la ciudad de Buenos Aires". Investigaciones OIC, Secretaria de Cultura del Gobierno de la ciudad de Buenos Aires.

*Peña Boerio, Victoria (2011), "Prácticas de distinción y consumo cultural de las clases medias: el caso de la música indie". Ponencia presentada en X Congreso Argentino de Antropología Social, Buenos Aires, 29 de noviembre al 1 de diciembre de 2011.

*Pujol, Sergio (2007), Rock y dictadura. Crónica de una generación (1976-1983), Buenos Aires, Emecé.

*Quiña, Guillermo Martín (2009a), “Consumos culturales y libertad creativa. El rol del productor artístico en la escena musical independiente." Ponencia presentada en XXVII Congreso ALAS, Buenos Aires, 31 de agosto al 4 de Septiembre de 2009. 
_ (2009b), ¿Amor a la música o pequeña industria cultural? Las múltiples dimensiones de la 'escena musical independiente' en el área metropolitana de Buenos Aires". Ponencia presentada en VIII Reunión de Antropología del Mercosur, Buenos Aires, 29 de septiembre al 3 de octubre de 2009.

_ (2012): "Entre la libre creación y la industria cultural. La producción musical independiente en la Ciudad de Buenos Aires desde 1999 a la actualidad". Tesis de Doctorado en Ciencias Sociales. Universidad de Buenos Aires.

_ y Mihal, Ivana (2011), "Entre libros y discos. Acerca de los sentidos de la producción cultural independiente". Ponencia presentada en XXVIII Congresso Internacional Da Alas, UFPE, Recife-PE, Brasil, 6 a 11 de septiembre de 2011.

*Rockwell, Elsie (2009), La experiencia etnográfica. Historia y cultura en los procesos educativos, Buenos Aires, Paidós.

*Salerno, Daniel y Silba, Malvina (2006), "Juventud, identidad y experiencia: las construcciones identitarias populares urbanas”, Revista Question N 10, La Plata.

*Seca, Jean Marie (2004), Los músicos underground, Paidós, Barcelona

*Semán, Pablo (2006), "El pentecostalismo y el rock chabón en la transformación de la cultura popular", en: MÍGUEZ, Daniel y SEMÁN, Pablo (eds.), Entre santos, cumbias y piquetes: las culturas populares en la Argentina reciente, Buenos Aires, Biblos.

_ y VILA, Pablo (2008): “La música y los jóvenes de los sectores populares: más allá de las "tribus",, Revista Transcultural de Música, no. 12. http://www.sibetrans.com/trans/trans12/art01.htm

_(2011), “Introducción” en Semán, Pablo y Vila, Pablo (comps.), Cumbia, nación, etnia y género en Latinoamérica. Buenos Aires, Editorial Gorla-Ediciones EPC.

*Shuker, Roy (2005), Diccionario del rock y la música popular, Barcelona, Ma non troppo.

*Silba, Malvina y Spataro, Carolina (2008), "Cumbia nena. Letras, relatos y bailes según las bailanteras", en: Alabarces, Pablo y Rodríguez, María Graciela (comps.), Resistencias y Mediaciones. Estudios sobre cultura popular, Buenos Aires, Paidós.

*Spataro, Carolina (2012), "Señora de las cuatro décadas: un estudio sobre el vínculo entre música, mujeres y edad", en: Revista da Associação Nacional dos Programas de Pós-Graduação em Comunicação, E-compós, Brasília, v.15, n.2, maio/ago. 2012 *Stahl, Geoff (2004) “"It's Like Canada Reduced”: Setting the Scene in Montreal', en Bennett, Andy and Kahn-Harris, Keith (eds.), After Subcultures, London: Ashgate. 
*Svampa, Maristella (2005): La sociedad excluyente. La Argentina bajo el signo del neoliberalismo. Buenos Aires, Taurus.

*Szpilbarg, Daniela (2010), "Editoriales artesanales y libros-arte: nuevos modos de producción y circulación social del libro. Reflexiones a partir del caso de las editoriales Funesiana y Clase Turista". Ponencia presentada en VI Jornadas de Sociología de la UNLP, La Plata, 9 y 10 de diciembre de 2010.

*Tranchini, Elina, Boix, Ornela, Castilla, Martín, Ferreya, M. José, Stefoni, Andrés (2009), "Una mano lava la otra. El circuito de los estudios barriales de producción de la cumbia en el Conurbano bonaerense". Ponencia presentada en VIII Reunión de Antropología del Mercosur, Buenos Aires, 29 de septiembre al 3 de octubre de 2009.

*Vanoli, Hernán (2009), "Pequeñas editoriales y transformaciones en la cultura literaria argentina”, en Apuntes de Investigación del CECYP, no. 15, Enero-Noviembre, Buenos Aires.

*Vecino, Diego (2010), "Nuevas prácticas y representaciones de los jóvenes de clase media en torno a la 'nueva cumbia' en la Ciudad de Buenos Aires". Ponencia presentada en II Reunión Nacional de Investigadoras/es en Juventudes Argentina, Ciudad de Salta, 13, 14 y 15 de octubre de 2010.

_ (2010b), “Sellos discográficos independientes y nuevas tecnologías en la crisis de la industria de la música. Los casos de los netlabels Ventolín Records y Mamushka Dogs Records”. Ponencia presentada en VI Jornadas de Sociología de la UNLP, La Plata, 9 y 10 de diciembre de 2010

_ (2011), "Nuevos sellos discográficos y la producción de música independiente en la ciudad de Buenos Aires, 1998-2010”, en Rubinich, Lucas y Miguel, Paula (comps.), 01 10. Creatividad, economía y cultura en la ciudad de Buenos Aires, Aurelia Rivera, Buenos Aires.

*Vicentini, Leila (2010), “Cultura, rock y jóvenes en La Plata”, en: Gutiérrez, Edgardo (ed.), Rock del país: estudios culturales de rock en Argentina. San Salvador de Jujuy: Universidad Nacional de Jujuy. Universitaria de Jujuy. Facultad de Humanidades y Ciencias Sociales.

*Vila, Pablo (1985), "Rock nacional: crónicas de la resistencia juvenil”, en JELIN, Elisabeth (comp.) Los nuevos movimientos sociales : mujeres, rock nacional, Centro Editor de América Latina, Buenos Aires.

_ (1987a): “Tango, folklore y rock: apuntes sobre música, política y sociedad en Argentina", en Cahiers du monde Hipsanique et Luso-Brésilien (Caravelle), Francia. 
(1987b) “El rock. Música argentina contemporánea". En Punto de Vista n³0. Juliooctubre 1987. Pp.23-29. Buenos Aires.

(1989), “Argentina's 'Rock Nacional': The Struggle for Meaning, en

Latin American Music Review / Revista de Música Latinoamericana, Vol. 10, No. 1 (Spring - Summer, 1989), pp. 1-28. University of Texas Press.

_ (1996): “Identidades narrativas y música. Una primera propuesta para entender sus relaciones", en Revista Transcultural de música, n. ${ }^{\circ} 2$. http://www.sibetrans.com/trans/a288/identidades-narrativas-y-musica-una-primerapropuesta-para-entender-sus-relaciones

_ (2010) El incremento de la agencia juvenil derivado de nuevas posibilidades tecnológicas. Mimeo.

*Waits, Jennifer C. (2007), 'Does 'indie' mean independence? Freedom and restraint in a late 1990s US college radio community”, en: The Radio Journal. International Studies in Broadcast and Audio Media, Volume 5, Numbers $2 \& 3$.

*Weber, S. y Mitchell, C. (2008) Imaginar, Mecanografiar y Nuevas Tecnologías, en: Buckingham D. (Ed.), Juventud, Identidad y Medios Digitales. Cambridge, MA: MIT Press.

*Welschinger, Nicolás (2013). "Jóvenes, escuela y nuevas tecnologías". Plan de Trabajo para Doctorado. Mimeo.

*Williams, Raymond (2000), Marxismo y literatura. Barcelona: Editorial Península.

*Willis, Paul (1978), Profane culture. London: Routledge \& Kegan Paul Books.

*Wolcott, Harry F. (2003), "En busca de la esencia de la etnografía" en http://www.antropologitosuv.com/article-28361125.html. (Consultado: 16/09/12).

*Woodside Woods, Julián; Jiménez López, Claudia y Urteaga Castro Pozo, Maritza (2011), "Creatividad y desarrollo: la música popular alternativa" en García Canclini, Néstor y Urteaga Castro Pozo, Maritza (Eds.) (2011), Cultura y desarrollo: una visión distinta desde los jóvenes. Avances de investigación. Madrid: Fundación Carolina.

*Wortman, Ana (1996), “Televisión e imaginarios sociales: Los programas juveniles" en Margulis, Mario (comp.), La juventud es más que una palabra, Buenos Aires, Biblos. *Yúdice, George (2002): El recurso de la cultura. Usos de la cultura en la era global. Barcelona, Gedisa.

_ (2007), Nuevas tecnologías, música y experiencia, Barcelona, Gedisa. 
_ (2008), "La transformación y diversificación de la industria de la música" en Bustamante, Enrique (ed.), La Cooperación cultura-Comunicación en Iberoamérica, Madrid, AECID

*Ziegler, Sandra (2007), "Los de excepción: un retrato de las elecciones escolares de las familias de sectores favorecidos en la Ciudad de Buenos Aires y el conurbano bonaerense" en Narodowski, Mariano y Gómez Schettini, Mariana (comps.), Escuelas y familias. Problemas de diversidad cultural y justicia social, Buenos Aires, Prometeo. 